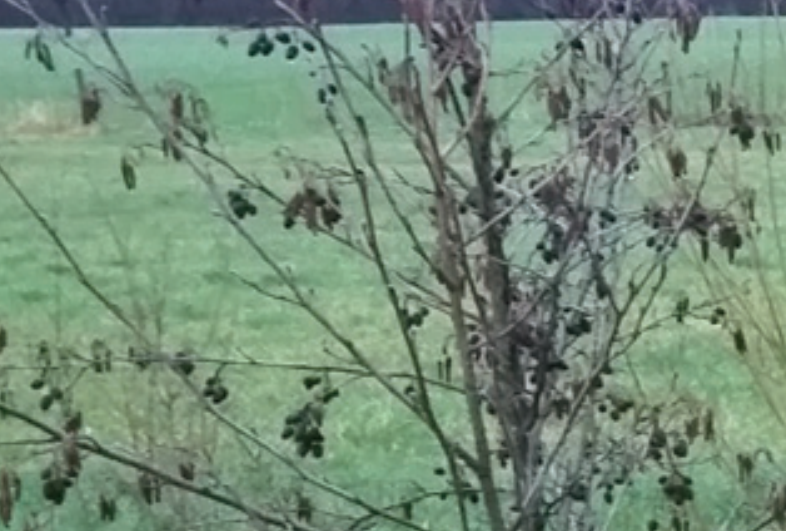





\section{Geomorfologische analyse van de Raamvallei}

Gilbert Maas, Bas van Delft, Gerben Mol

Dit onderzoek is uitgevoerd door Wageningen Environmental Research in opdracht van en gefinancierd door het ministerie van Landbouw, Natuur en Voedselkwaliteit, in het kader van het Kennisbasis onderzoeksthema 'System Earth Management' (projectnummer KB-24-001-017), het ministerie van Infrastructuur en Milieu en het Waterschap Aa en Maas in het kader van het Programma Lumbricus, Wageningen Environmental Research

Wageningen, december 2018

Rapport 2918

ISSN 1566-7197 
Maas, G.J., S.P.J. van Delft, G. Mol, 2018. Geomorfologische analyse van de Raamvallei. Wageningen, Wageningen Environmental Research, Rapport 2918. 80 blz.; 46 fig.; 14 tab.; 26 ref.

In de Raamvallei wordt het beekdal opnieuw ingericht. Doelen voor de Raamvallei zijn ruimte voor duurzame landbouw in combinatie met voldoende en schoon water en ecologische herstel van het beeksysteem. Een pijler van goede planvorming is gedegen inzicht in de hydrologische, (landschaps)ecologische en morfologische werking van het stroomgebied en beeksysteem in het hele beekdal. Door inrichtingsmaatregelen (beter) aan te laten sluiten bij de natuurlijk condities en processen - Building with Nature (BwN) - zijn er mogelijk nieuwe oplossingen die goedkoper en duurzamer zijn dan traditionele oplossingen.

Trefwoorden: Hooge Raam, Lumbricus, Building with Nature, Landschapsleutel, geomorfologie, beekherstel, landschapsecologische systeemanalyse, moerasbeek

Dit rapport is gratis te downloaden van https://doi.org/10.18174/467002 of op www.wur.nl/environmental-research (ga naar 'Wageningen Environmental Research' in de grijze balk onderaan). Wageningen Environmental Research verstrekt geen gedrukte exemplaren van rapporten.

(2) 2018 Wageningen Environmental Research (instituut binnen de rechtspersoon Stichting Wageningen Research), Postbus 47, 6700 AA Wageningen, T 03174807 00, www.wur.nl/environmental-research. Wageningen Environmental Research is onderdeel van Wageningen University \& Research.

- Overname, verveelvoudiging of openbaarmaking van deze uitgave is toegestaan mits met duidelijke bronvermelding.

- Overname, verveelvoudiging of openbaarmaking is niet toegestaan voor commerciële doeleinden en/of geldelijk gewin.

- Overname, verveelvoudiging of openbaarmaking is niet toegestaan voor die gedeelten van deze uitgave waarvan duidelijk is dat de auteursrechten liggen bij derden en/of zijn voorbehouden.

Wageningen Environmental Research aanvaardt geen aansprakelijkheid voor eventuele schade voortvloeiend uit het gebruik van de resultaten van dit onderzoek of de toepassing van de adviezen.

Wageningen Environmental Research Rapport 2918 | ISSN 1566-7197

Foto omslag: Beverdam in de Hooge Raam (Foto: Gilbert Maas) 


\section{Inhoud}

Woord vooraf $\quad 5$

$\begin{array}{ll}\text { Samenvatting } & 7\end{array}$

1

$\begin{array}{ll}\text { Inleiding } & 9\end{array}$

1.1 Achtergrond en doelstelling 9

1.2 Selectie van beken in de Raamvallei 9

1.3 Geomorfologische beek-analyse: de methodiek 10

1.3.1 Ruimtelijke Systeemanalyse Raamvallei en de geselecteerde beken $\quad 10$

1.3.2 Voorspelling van dimensies beekpatronen, sedimenttransport en bankvormen in dynamische evenwicht

1.3.3 Evaluatie van de ruimtelijke systeemanalyse en voorspelde patronen in het veld

1.3.4 Maatregelen in het licht van referentiebeelden ten aanzien van de beken in de Raamvallei

2.1 Landschappelijke en historische context

2.1.1 Geo(morfo)logie en historische context 14

$\begin{array}{ll}2.1 .2 \text { Substraat } & 18\end{array}$

$\begin{array}{ll}2.1 .3 \text { Historische context } & 20\end{array}$

2.1.4 Actueel oppervlakte watersysteem $\quad 22$

2.1.5 Landschappelijke Bodemkaart $\quad 23$

2.1.6 Potentiële (semi)terrestrische vegetatie 33

2.2 Beekpatronen, sedimenttransport en bankvorming in de Raamvallei 34

2.2.1 Geultype $\quad 34$

2.2.2 Geulbreedte en geuldiepte in een evenwichtssituatie 36

$\begin{array}{ll}2.2 .3 \text { Beddingmorfologie en bankvorming } & 37\end{array}$

$3 \quad$ Factsheets voor de beeklopen in de Raamvallei 40

$\begin{array}{lll}3.1 & \text { Graafsche Raam } & 41\end{array}$

3.1.1 Systeemkenmerken Graafsche Raam $\quad 42$

$\begin{array}{ll}3.1 .2 \text { Veldwaarnemingen } & 42\end{array}$

3.2 Hooge Raam $\quad 44$

3.2.1 Systeemkenmerken Hooge Raam $\quad 45$

3.2.2 Veldwaarnemingen $\quad 46$

$\begin{array}{lll}3.3 & \text { Halsche Beek } & 47\end{array}$

3.3.1 Systeemkenmerken Halsche Beek $\quad 47$

$\begin{array}{ll}3.3 .2 \text { Veldwaarnemingen } & 47\end{array}$

3.4 Lage Raam $\quad 49$

3.4.1 Systeemkenmerken Lage Raam 51

3.4.2 Veldwaarnemingen $\quad 51$

3.5 Biestgraaf $\quad 52$

3.5.1 Systeemkenmerken Biestgraaf $\quad 52$

$\begin{array}{ll}3.5 .2 \text { Veldwaarnemingen } & 53\end{array}$ 
4.1 Landschapsecologische referentiebeelden voor de Raamvallei 54

4.1.1 Bovenstroomse kwelmoerassen en bronbeken 56

4.1.2 Snelstromende terrasbeek met zandbedding 59

4.1.3 Kwelmoeras hellingvoet terrasrand $\quad 62$

4.1.4 Moerasbeek in verlande restgeul in het rivierenlandschap 66

4.2 Building with Nature-maatregelen in de Raamvallei 69

$\begin{array}{ll}\text { Literatuur } & \mathbf{7 1}\end{array}$

Bijlage 1 Fysisch- en historisch- geografische kaart van het $\begin{array}{ll}\text { Maasstuwpand Grave } & 73\end{array}$

$\begin{array}{lll}\text { Bijlage 2 } & \text { Bodemkaarten } & 74\end{array}$

$\begin{array}{lll}\text { Bijlage 3 Profielbeschrijvingen } & 76\end{array}$

$\begin{array}{lll}\text { Bijlage } 4 & \text { Potentiële vegetaties } & 77\end{array}$ 


\section{Woord vooraf}

Dit rapport maakt deel uit van het onderzoek dat binnen het Programma Lumbricus, thema Boeiende Beekdalen, pijler Ontwikkelpaden, wordt uitgevoerd in Proeftuin Zuid, de Raamvallei. De opgave die het thema Boeiende Beekdalen zich stelt, is om bij te dragen aan de ontwikkeling van een flexibele en klimaat-robuuste inrichting van beken en beekdalen met de hierbij behorende beheerstrategieën. Daarbij wordt ervaring met 'Building with Nature'-principes opgedaan. Bouwen met de natuur betekent meer ruimte laten voor en gebruikmaken van natuurlijke processen binnen de kaders die de gebruiksfuncties van de watergang bieden. De tussentijdse resultaten van deze studie zijn op 31-08-2017 gepresenteerd op een werksessie 'Inrichting Hooge Raam' te Cuijk. 


\section{Samenvatting}

In de Raamvallei wordt het beekdal opnieuw ingericht. Hiervoor wordt door het Waterschap Aa en Maas, in samenwerking met gebiedspartijen, een Gebiedsplan 'Raamvallei' opgesteld. Doelen voor de Raamvallei zijn ruimte voor duurzame landbouw, in combinatie met voldoende en schoon water en ecologisch herstel van het beeksysteem. Een pijler van goede planvorming is gedegen inzicht in de hydrologische, (landschaps)ecologische en morfologische werking van het stroomgebied en beeksysteem in het hele beekdal. Door inrichtingsmaatregelen (beter) aan te laten sluiten bij de natuurlijk condities en processen - Building with Nature (BwN) - zijn er mogelijk nieuwe oplossingen die goedkoper en duurzamer zijn dan traditionele oplossingen.

Dit project - dat gezien moet worden als een verkenning - heeft twee doelen:

- Een geomorfologische analyse uitvoeren van een aantal beken in de Raamvallei waarin potentiële en actuele morfologische processen in het beeksysteem beschreven worden, met onder andere aandacht voor erosie, sedimentatie en transport van zand en slib.

- Het identificeren van maatregelen die deze morfologische processen zodanig beïnvloeden dat het beeksysteem zich ontwikkelt in de richting van een referentiebeeld dat past bij de geomorfologische karakteristieken van het gebied.

Voor de geomorfologische analyse van de beken in de Raamvallei is de systematiek van het Handboek Geomorfologische beekherstel toegepast (Makaske \& Maas, 2015). In deze methode, die werkt volgens een stappenplan, is achtereenvolgens de landschapsecologische en historische context van het systeem onderzocht, zijn de geomorfologische karakteristieken van de beeklopen in de actuele situatie en de referentiesituatie beschreven en zijn ten slotte BwN-maatregelen geïdentificeerd om de beek te ontwikkelen in de richting van de referentie.

Om de landschapsecologische context van de beekdalgronden die binnen het hydrologische beïnvloedingsgebied vanuit de beek gelegen zijn te kunnen beschrijven, is gebruikgemaakt van de indeling volgens 'De Landschapsleutel' (Kemmers et al., 2011; Delft et al., 2015). Dit is een werkwijze waarbij op basis van geomorfologie, bodem, overstromingsdynamiek en aanvullende informatie de landschapsecologische positie van een perceel of kaartvlak beoordeeld kan worden.

De landschapsecologische en geomorfologische analyse hebben geleid tot het opstellen van vier referentiebeelden voor de Raamvallei:

- Bovenstroomse kwelmoerassen en bronbeken

- Snelstromende terrasbeek met een zandbedding

- Kwelmoeras hellingvoet

- Moerasbeek in verlande restgeul

De geschetste referentiebeelden voor de Raamvallei staan niet onafhankelijk van elkaar, maar kunnen alleen in samenhang worden ontwikkeld. Met andere woorden: (bovenstrooms) kwelmoeras, snelstromende terrasbeek en moerasbeek in de benedenloop vormen een samenhangende referentie voor de Raamvallei. Om een dergelijke referentie op systeemniveau te realiseren, is een planproces nodig dat uitgaat van een visie op het gehele beeksysteem. Vanuit die visie op stroomgebiedsniveau kunnen bouwstenen worden geïdentificeerd voor beekherstel voor de verschillende beektrajecten (Wolfert et al., 2009). Per beektraject en bouwsteen kunnen vervolgens BwN-maatregelenpakketten worden samengesteld. De lijst in dit verkennende rapport is overigens niet uitputtend en wordt idealiter in het kader van programma Lumbricus verder uitgebreid en getoetst in veldexperimenten. 


\section{$1 \quad$ Inleiding}

\subsection{Achtergrond en doelstelling}

In de Raamvallei wordt het beekdal opnieuw ingericht. Hiervoor wordt door het Waterschap Aa en Maas, in samenwerking met gebiedspartijen, een Gebiedsplan 'Raamvallei' opgesteld. Doelen voor de Raamvallei zijn ruimte voor duurzame landbouw in combinatie met voldoende en schoon water en ecologisch herstel van het beeksysteem. Een pijler van goede planvorming is gedegen inzicht in de hydrologische- (landschaps)ecologische en morfologische werking van het stroomgebied en beeksysteem in het hele beekdal. Door inrichtingsmaatregelen (beter) aan te laten sluiten bij de natuurlijk condities en processen - Building with Nature (BwN) - zijn er mogelijk nieuwe oplossingen die goedkoper en duurzamer zijn dan traditionele oplossingen.

In dit kader is de Raamvallei door het waterschap Aa en Maas voorgedragen als een van de proeftuinen in het onderzoeksprogramma Lumbricus. Het programma Lumbricus zet in op een klimaatrobuuste inrichting van het bodem- en watersysteem. Het Lumbricus deelprogramma Boeiende Beekdalen richt zich op het ontwikkelen van kennis over een optimale benutting van natuurlijke (morfologische) processen voor ontwikkeling en beheer van beken (en kleine rivieren), in de beken zelf en in de beekdalgronden die binnen het hydrologische beïnvloedingsgebied van de beek liggen. Boeiende Beekdalen wil bestaande kennis over bouwen met de natuur integreren en opschalen en de kennislacunes vullen met 'real life'-experimenten in de proeftuinen.

De geomorfologische systeemanalyse van de Raamvallei in dit rapport is onderdeel van het operationele plan Boeiende Beekdalen. De maatregelen die worden voorgesteld op basis van de resultaten van dit onderzoek vormen een uitganspunt van het experimentele onderzoek in de vervolgfase van het Lumbricus-programma in proeftuin Raamvallei.

De twee doelen van dit verkennende project zijn:

1. Een geomorfologische analyse uitvoeren van een aantal beken in de Raamvallei waarin potentiële en actuele morfologische processen in het beeksysteem beschreven worden, met onder andere aandacht voor erosie, sedimentatie en transport van zand en slib.

2. Het identificeren van maatregelen die deze morfologische processen zodanig beïnvloeden dat het beeksysteem zich ontwikkelt in de richting van een referentiebeeld dat past bij de geomorfologische karakteristieken van het gebied.

\subsection{Selectie van beken in de Raamvallei}

Dit onderzoek richt zich op de volgende beeklopen in de Raamvallei:

- Graafsche Raam

- Lage Raam: benedenloop en middenloop

- Biestgraaf (bovenstrooms Laarakkerse waterleiding geheten)

- Hooge Raam

- Halsche Beek

We gebruiken wel de beschikbare en relevantie informatie uit het gehele stoomgebied, maar de geomorfologische analyse beperkt zicht tot deze beeklopen, die ook zijn weergegeven in Figuur 1-1. 


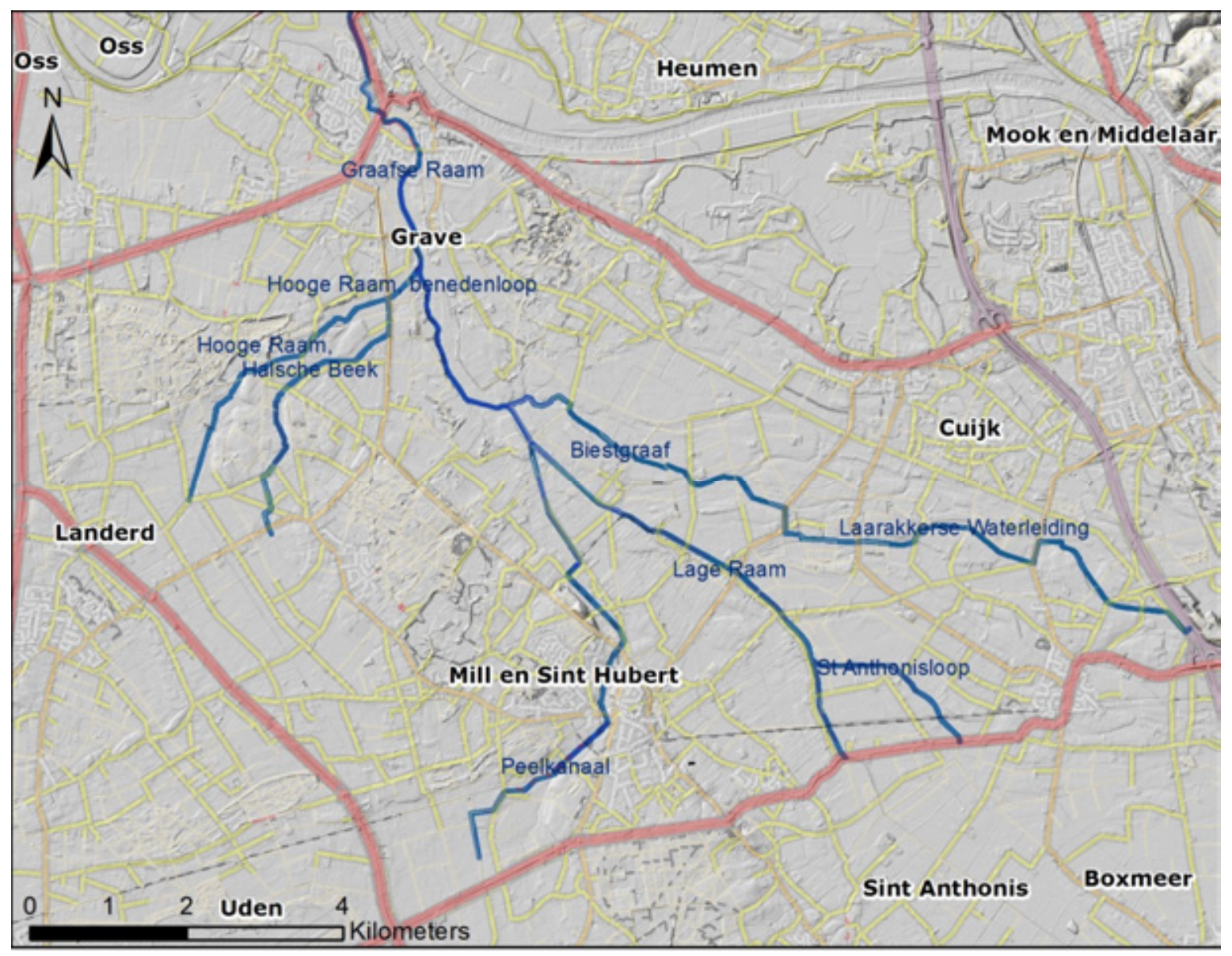

Figuur 1-1 Kaart van de geselecteerde beken in de Raamvallei.

\subsection{Geomorfologische beek-analyse: de methodiek}

Voor de geomorfologische analyse van de beken in de Raamvallei passen we de systematiek van het Handboek Geomorfologische beekherstel toe (Makaske \& Maas, 2015). In deze systematiek worden de volgende stappen onderscheiden:

1. Ruimtelijke oriëntatie op de landschappelijke en historische context van de geselecteerde beeklopen.

2. Voorspelling van het beekpatroon, de sedimentmobiliteit en de beddingvormen, passend bij de actuele condities of condities in de nabije toekomst (referentiebeeld) per beekloop.

3. Evaluatie van het geulpatroon aan de hand van een veldcheck.

4. Bepaling van de (ontwerp)dimensies voor geulen in een dynamisch evenwicht per beekloop.

5. Identificeren van maatregelen door de bestaande uitganssituatie te vergelijken met patroon/dimensies van de beek in evenwicht en het referentiebeeld van het beeksysteem.

Bij de bespreking worden de stappen 2 en 4 tezamen genomen, omdat stap 4 direct gekoppeld is aan stap 2. Hierin worden alleen details herzien als stap 3, de veldcheck, daartoe aanleiding geeft.

\subsubsection{Ruimtelijke Systeemanalyse Raamvallei en de geselecteerde beken}

Op basis van bestaande (kaart)bronnen en beschikbare informatie bij het waterschap en bij Wageningen Environmental Research (Alterra) wordt een gebiedsanalyse van de Raamvallei gemaakt die is opgedeeld in drie categorieën, namelijk (1) de geomorfologische en historische context, (2) de context van de landschappelijk bodemkaart en (3) de betekenis van deze abiotische omstandigheden voor potentiële (semi-)terrestrische vegetatietypen. 
In deze onderdelen wordt aandacht besteed aan de volgende aspecten:

- geologische, geomorfologische en bodemkundige situatie van de Raamvallei;

- (geo-)hydrologische situatie (grondwater, kwel), globale afvoerdynamiek gerelateerd aan inundaties:

- het (historisch) landgebruik in het stroomgebied;

- bestaande ecologische waarden in het stroomgebied;

- het oppervlaktewatersysteem.

Deze aspecten worden alleen beschreven voor zover ze van belang zijn voor de geomorfologische beek-analyses. Op basis van de eerste verkenning van deze informatie is de Raam ingedeeld in deeltrajecten, waarbinnen de landschappelijke condities vergelijkbaar zijn en die worden weergegeven in Figuur 1-1.

De analyses die per beek zullen volgen in de rest van dit rapport, zijn gebaseerd op deze basisinformatie en geven antwoord op de volgende vragen:

- het type beek in morfologische zin;

- morfologische landschappelijke setting van de beek; ingesneden beekdal of overstromingsvlakte; natuurlijk dimensies van het dal/vlakte en hoe worden deze begrensd;

- voorkomen van oude beddingen in relatie met historische morfodynamiek;

- de gelaagdheid en de samenstelling/textuur van het bodemmateriaal in (de ondergrond) van het beekdal (grond, zand, klei veen) en de invloed daarvan op de morfologie van de beek;

- de bodemtypen in het dal en de betekenis daarvan in morfologische/ecologische zin;

- invloed van grondwater/kwel/inundatie op de morfologie van de beek;

- invloed van de mens op de morfologische ontwikkeling van de beek.

\subsubsection{Voorspelling van dimensies beekpatronen, sedimenttransport en bankvormen in dynamische evenwicht}

De voorspelling van het geulpatroon geeft inzicht in de potenties voor morfologische processen in de actuele situatie of de nabije toekomst (na uitvoering van maatregelen) voor een beek die in een dynamisch evenwicht verkeert. Het geulpatroon is een schakel in de opstelling van het referentiebeeld of toetsing van bestaande referentiebeelden aan de geomorfologische mogelijkheden die het gebied biedt.

Het geulpatroon wordt voor de onderscheiden deeltrajecten voorspeld aan de hand van de positie in het stabiliteitsdiagram (Makaske \& Maas, 2014). Het stabiliteitsdiagram geeft aan wanneer een beek actief meandert, vlechtend is of stabiel. Kleine veranderingen in de sturende factoren kunnen soms leiden tot een ander geultype. Voor een bepaling in het stabiliteitsdiagram is een aantal gegevens nodig: de geulvullende afvoer, het dalverhang en de korrelgrootte van het sediment in de beek. Vervolgens wordt met de volgende formule het potentiële specifieke stromingsvermogen uitgerekend:

$$
\omega_{\mathrm{pv}}=\mathrm{e}^{*} \mathrm{~g} * \mathrm{Q} * \mathrm{~S}_{\mathrm{v}} / \mathrm{W}_{\mathrm{r}}
$$

$\mathrm{e}=$ dichtheid van water: $\mathrm{kg} / \mathrm{m}^{3}$

$\mathrm{g}=$ zwaartekrachtversnelling: $\mathrm{m} / \mathrm{s}^{2}$

$\mathrm{Q}=$ dominante of geulvormende afvoer: $\mathrm{m}^{3} / \mathrm{s}$

$\mathrm{Sv}=$ helling van dal of vlakte: $\mathrm{m} / \mathrm{km}$

$\mathrm{Wr}=$ breedte van de referentiegeul $=4,7 * \sqrt{ } \mathrm{Q}=\mathrm{m}$

$\omega p v=$ potentieel specifiek stromingsvermogen: $\mathrm{W} / \mathrm{m}^{2}$

De uitkomst hiervan wordt geplot in het stabiliteitsdiagram waarvan Figuur 1-2 een voorbeeld weergeeft. De scheidlijnen tussen de velden zijn geen harde grenzen, maar moeten opgevat worden als het midden van een overgangszone en ondergrens voor het voorkomen van een bepaald geultype (Makaske \& Maas, 2014). 


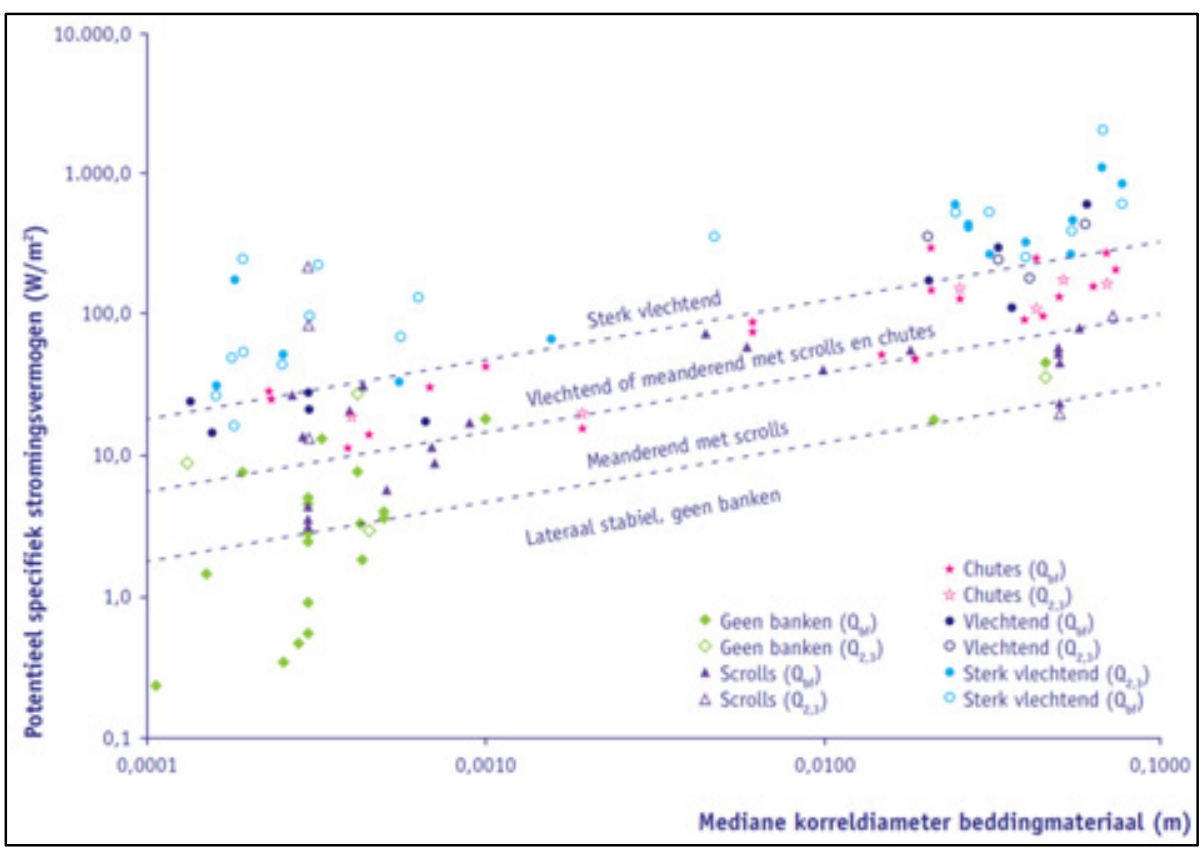

Figuur 1-2 Stabiliteitsdiagram voor geulpatronen.

Daarnaast worden de diagrammen voor beddingvormen en bankvormen gebruikt (zie Figuur 2-9) en worden formules gebruikt om gegeven de geomorfologische en hydraulische situatie (afvoerdynamiek) de te verwachten geuldiepte en geulbreedte te berekenen. Deze breedte en diepte beschrijven de situatie van een geul in een dynamisch evenwicht. De breedte en diepte van de geul worden berekend met de volgende hydraulische geometrische relaties (Makaske en Maas, 2014):

Geulbreedte

$$
\mathrm{W}=\mathrm{a} * \mathrm{Q}^{\mathrm{b}}
$$

$a=$ coëfficiënt:

$b=$ coëfficiënt:

$\mathrm{Q}=$ geulvormende afvoer: $\left(\mathrm{m}^{3} / \mathrm{s}\right)$

$\mathrm{W}=$ geulbreedte $(\mathrm{m})$

Coëfficiënt $a$ is afhankelijk van de sedimentkarakteristieken en de oeverbegroeiing van de geul en ligt voor beken en rivieren met een zandige bedding tussen de 3,5 en 6,5. Gesteld kan worden dat geulen met onbegroeide oevers in zandig sediment het breedst zijn en dat grind in de bedding en dichtbegroeide en cohesieve oevers de geulbreedte beperken. Op basis van ervaringen van Van den Berg (1995) en Hobo (2006) is voor de beken met een zandige bedding en weinig cohesieve oevers de waarde van coëfficiënt a op 5 gesteld en voor de beken met een zandbedding met veen of kleiig sediment in de oevers op 4. De waarde voor coëfficiënt a bij grindige bedding varieert van 1,8 tot 4,33 (Makaske en Maas, 2014).

Uit onderzoek is gebleken dat de variatie in coëfficiënt b beperkt is en daarvoor meestal een vaste waarde van 0,5 wordt gehanteerd.

Geuldiepte (volgens Brownlie)

$$
\mathrm{R}=\mathrm{S}^{-0,2542} * 0,3724 * \mathrm{D}_{50} * \mathrm{Q}^{0,0,6539} * \sigma_{\mathrm{s}}{ }^{0,1050}
$$

$\mathrm{S}=$ geulgradiënt: $\mathrm{m} / \mathrm{km}$

$\mathrm{Q}^{*}=$ dimensieloze afvoer $=\mathrm{Q} /\left(\mathrm{W} * \mathrm{~g}^{0,5} * \mathrm{D}_{50}{ }^{1,5}\right)$

$\mathrm{Q}=$ afvoer: $\mathrm{m}^{3} / \mathrm{s}$

$\mathrm{W}=$ geulbreedte: $\mathrm{m}$

$\mathrm{g}=$ zwaartekrachtversnelling: $\mathrm{m} / \mathrm{s}^{2}$ 
$\sigma_{s}=$ sortering beddingmateriaal $=1 / 2\left(D_{50} / D_{16}+D_{84} / D_{50}\right):$

$D_{16}=16$ percentiel korrelgrootte $(m)$

$D_{50}=$ mediane korrelgrootte $(m)$

$D_{84}=84$ percentiel korrelgrootte $(\mathrm{m})$

$\mathrm{R}=$ hydraulische straal $\approx$ natuurlijke gemiddelde diepte: $\mathrm{m}$

\subsubsection{Evaluatie van de ruimtelijke systeemanalyse en voorspelde patronen in het} veld

De in § 1.3.1 en 1.3.2 vastgestelde morfologische kenmerken van de onderscheiden beektrajecten op basis van bestaande bronnen en morfometrische modellen zijn vervolgens in het veld getoetst.

Tijdens de veldtoets waarbij alle beektrajecten zijn bezocht is aandacht besteed aan:

- zichtbare actuele morfologische processen (oevererosie, bedding vormen, bankvorming, sedimentatie van zand en slib);

- geulpatronen;

- terreinvormen gerelateerd aan morfodynamiek in het verleden;

- beddingsubstraat;

- kwel in de oeverzone;

- bodemgelaagdheid en textuur oeverzone;

- (extreme)vegetatieontwikkeling in de geul.

Met de gegevens uit de veldtoets is de morfologische typering uit fase 1.3.1 en 1.3.2 geëvalueerd en waar nodig aangepast. De veldtoets gaf geen aanleiding om de grenzen van de deeltrajecten aan te passen.

\subsubsection{Maatregelen in het licht van referentiebeelden ten aanzien van de beken in de Raamvallei}

In de laatste fase van het project worden in overleg met de opdrachtgever maatregelen vastgesteld die kunnen bijdragen aan het bereiken van het wensbeeld van het Waterschap Aa en Maas ten aanzien van de beken in de Raamvallei, in het licht van de resultaten van de gebiedsanalyse in dit onderzoek. Daarbij zijn de volgende twee vragen aan de orde:

- In hoeverre past het morfologische referentiebeeld bij het wensbeeld (of andersom) en is bijstelling van het wensbeeld gewenst, gegeven de abiotische karakteristieken van het gebied?

- Welke maatregelen kunnen genomen worden om de beek in de huidige situatie te bewegen richting het referentiebeeld? 


\section{Resultaten Raamvallei}

\subsection{Landschappelijke en historische context}

\subsubsection{Geo(morfo)logie en historische context}

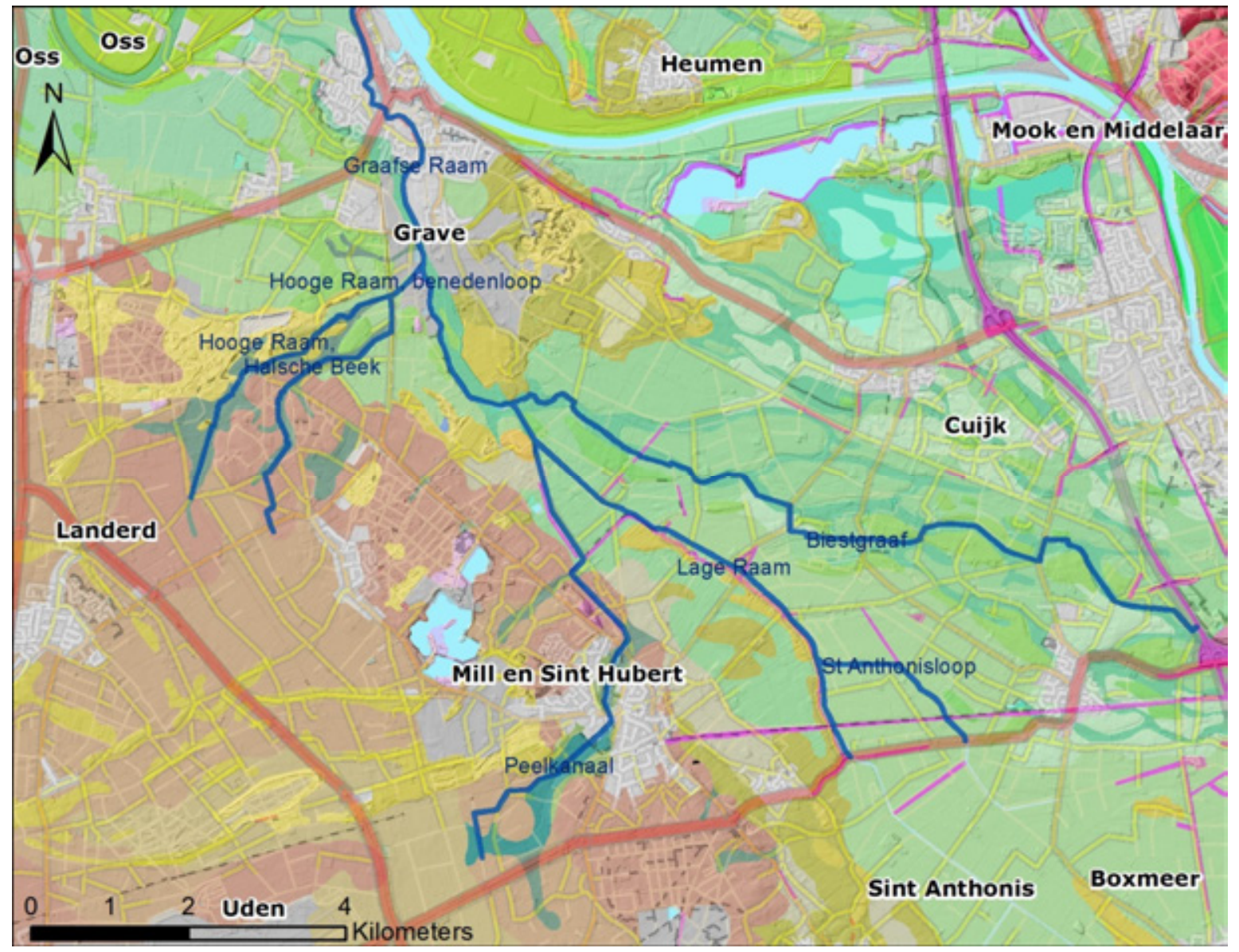

Figuur 2-1 Geomorfologische kaart van de Raamvallei-regio.

In Figuur 2-1 zijn de belangrijkste waterlopen in de Raamvallei-regio geprojecteerd op de geomorfologische kaart van Nederland 1:50.000. De Raamvallei-regio valt uiteen in twee geo(morfo)logische landschappen: de Peelhorst in het zuidwesten (bruine tinten) en het rivierterrassenlandschap van de Niersdal-Rijn en Maas in het noordoosten (groenblauwe tinten). De Peelhorst is van oorsprong ook een oud Maasterras, maar door afschuiving langs meerdere geologische breuken is dit deel van het aardoppervlak omhooggekomen (Figuur 2-3). Aan de westzijde (buiten het kaartbeeld) wordt de Peelhorst begrensd door de Peelrandbreuk en de Roerdalslenk. Een slenk is het relatief laaggelegen gebied dat bij hetzelfde tektonische proces naar beneden is gezakt. De breuk en de terreintrede van horst naar slenk vallen hier samen. Aan de oostzijde wordt de Peelhorst begrensd door de Venloslenk met daarin het Rijn-Maasdal. Hier valt de terreintrede van horst naar slenk niet samen met de breuk (breuk van Grave), maar ligt de breuk ca. 1,5 km ten oosten van de terreintrede. De verschuiving van de terreintrede ten opzichte van de breuk naar het westen is naar alle waarschijnlijkheid veroorzaakt door eroderende werking van de Niersdalrijn en Maas. De relatief smalle doorgang tussen de stuwwal van Nijmegen en de Peelhorst heeft voor de vlechtende pleistocene rivieren als een flessenhals gewerkt. Als gevolg daarvan is de noordoostflank van de Peelhorst sterk geërodeerd (Figuur 2-2). Het maximale hoogteverschil aan maaiveld tussen de horst en de Venloslenk binnen het studiegebied bedraagt ca. $10 \mathrm{~m}$. 


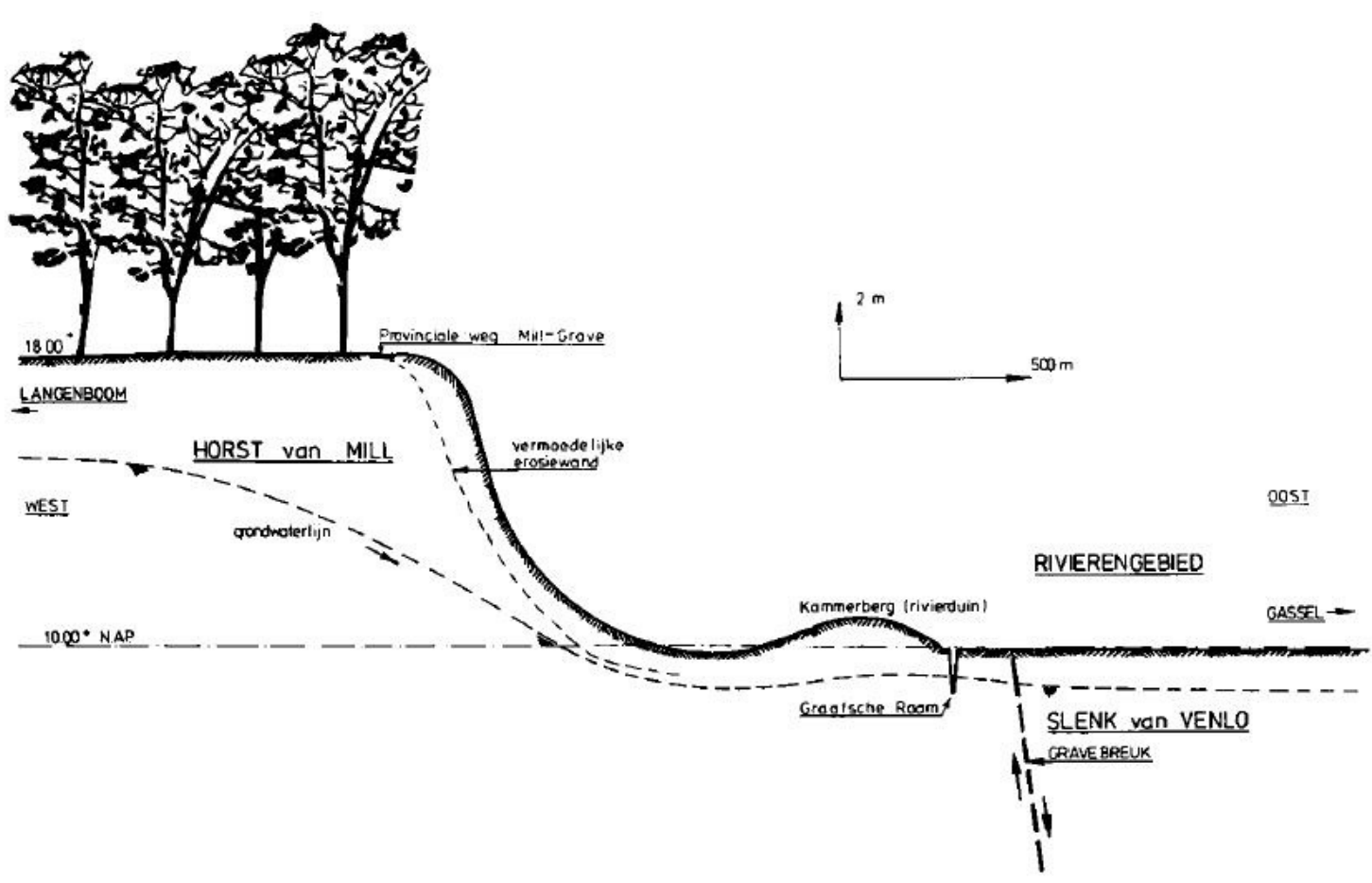

Figuur 2-2 Dwarsprofiel door de oostelijke terreintrede van de Peelhorst naar het rivierengebied (Hoogma, 1979).

De Peelhorst bestaat aan maaiveld uit een pakket vroege en midden pleistocene afzettingen van de Maas, overwegend grof zand en grind met lokaal kleischollen (Formatie van Beegden). (zie Figuur 2-4

Geologisch dwarsprofiel door het studiegebied Raamvallei. De verticale lijnen geven de knikpunten in het dwarsprofiel weer en vallen globaal samen met het dal van de Hooge Raam (Dinoloket, 2016). Deze oude Maasafzettingen zijn lokaal bedekt met dekzand, sneeuwsmeltwaterafzettingen en stuifzand (Formatie van Boxtel). Onder de Maasafzettingen van de Formatie van Beegden liggen pre-pleistocene rivierafzettingen (zanden), behorend tot de formatie van Oosterhout en Peize/Waalre op afzettingen van de Formatie van Breda. De Formatie van Breda bestaat uit een 'ondiep mariene en in de kustzone gevormde afzettingen'. De textuur van deze afzettingen is:

- Zand, zeer fijn tot matig fijn siltig, glauconiet- en kalkhoudend;

- Klei, sterk zandig tot matig siltig; 


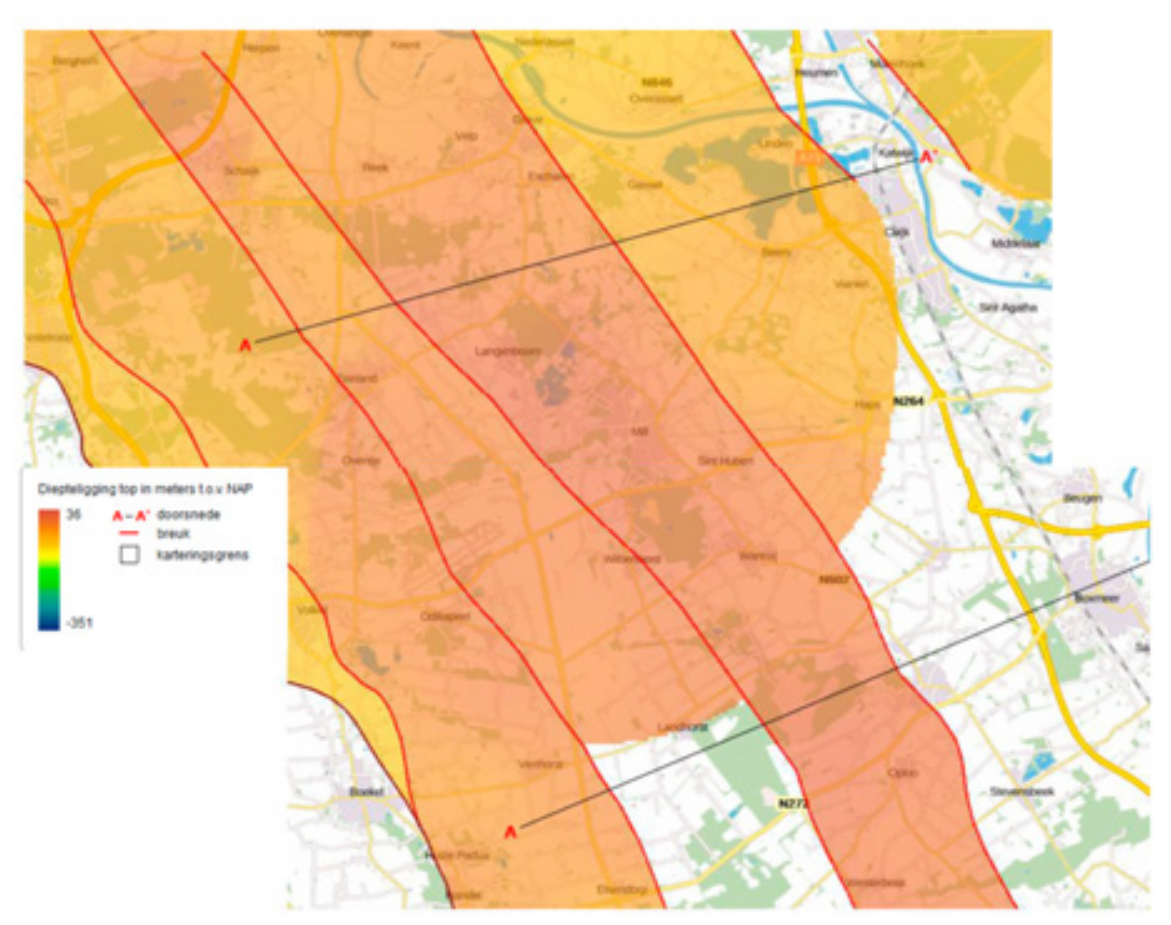

Figuur 2-3 Ligging van de breuken (rode lijnen) en diepteligging in $m+N A P$ van de top van de eerste kleiige eenheid van de Formatie van Breda (Bron: REGIS II v2.1 uit: Watersysteemverkenning Raamvallei).

Door tektoniek langs verschillende breuken in de ondergrond ligt de top van de Formatie van Breda ter plaatse van de Hooge Raam relatief hoog in het profiel. Dit deel van de peelhorst wordt ook wel de horst van Mill genoemd (Hoogma, 1979).

Op flank van de Peelhorst naar de Venloslenk is door afstromend sneeuwsmeltwater een aantal erosiedalen gevormd. Deze dalen zijn gedeeltelijk weer opgevuld met matig fijnzandige (beek)afzettingen en lokaal met veen. De Hooge Raam, Halsche Beek en Peelkanaal volgen de loop van deze dalen. 


\section{Verticale Doorsnede DGM v2.2}

Hoogte to.v. NAP: -114

A
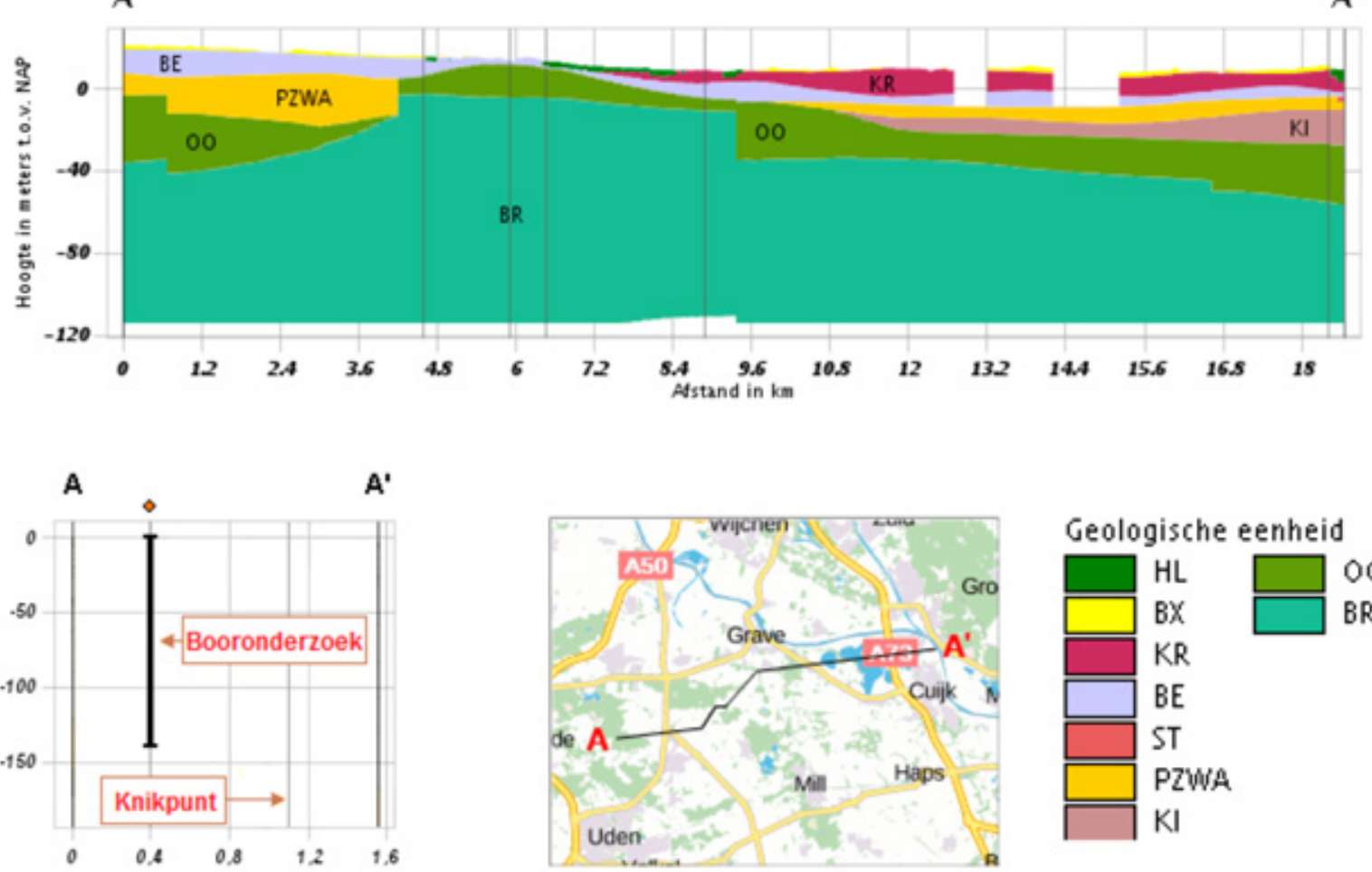

\section{Geologische eenheid}

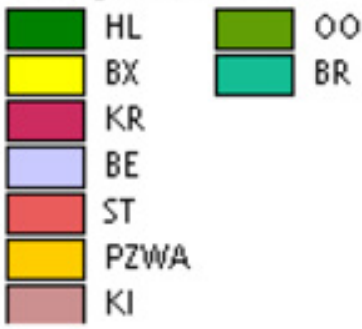

Figuur 2-4 Geologisch dwarsprofiel door het studiegebied Raamvallei. De verticale lijnen geven de knikpunten in het dwarsprofiel weer en vallen globaal samen met het dal van de Hooge Raam (Dinoloket, 2016).

Het rivierterrassenlandschap in de Venloslenk bestaat uit laat-pleistocene rivierafzettingen van de Rijn en Maas. Deze afzettingen worden gerekend tot de Formatie van Kreftenheye en bestaan voornamelijk uit matig grove tot grove rivierzanden. De formatie van Kreftenheye ligt hier op de oudere Maasafzettingen en de marine afzetting van de Formatie van Breda. Binnen het Kreftenheye rivierterras is een tweedeling aanwezig (zie Bijlage 1). Het oudste deel van het terras (Pleniglaciaal, Kreftenheye 4/5) grenst aan de Peelhorst en kenmerkt zich door het ontbreken van duidelijke restgeulen. De Lage Raam en St. Anthonisloop liggen in dit terras. Het terrasgedeelte waarin wel duidelijke restgeulen liggen, is in een latere fase gevormd (Laat Pleniglaciaal 'Laagterras' van de Niersdalrijn, Kreftenheye-5 Formatie). Naast de restgeulen treffen we hier ook langs de geulen rivierduinen aan en is er op de terrasvlakte oude rivierklei afgezet. De Biestgraaf volgt in zijn loop een aantal van de restgeulen in het terras evenals de Graafsche Raam.

In het Holoceen is op beide terrassen in het studiegebied jonge rivierklei afgezet (Formatie van Echteld). Tot 1942 maakt het rivierterras deel uit van de Beersche Overlaat (Figuur 2-5). Bij hoogwater op de Maas inundeerde het gebied, waarbij het water binnendijks via een systeem van binnendijkse overlaten werd afgevoerd en voorbij Den Bosch weer op de Maas werd geloosd. De restgeul die samenvalt met de Graafsche Raam is gedurende het Holoceen onder stagnante omstandigheden opgevuld met veen. 


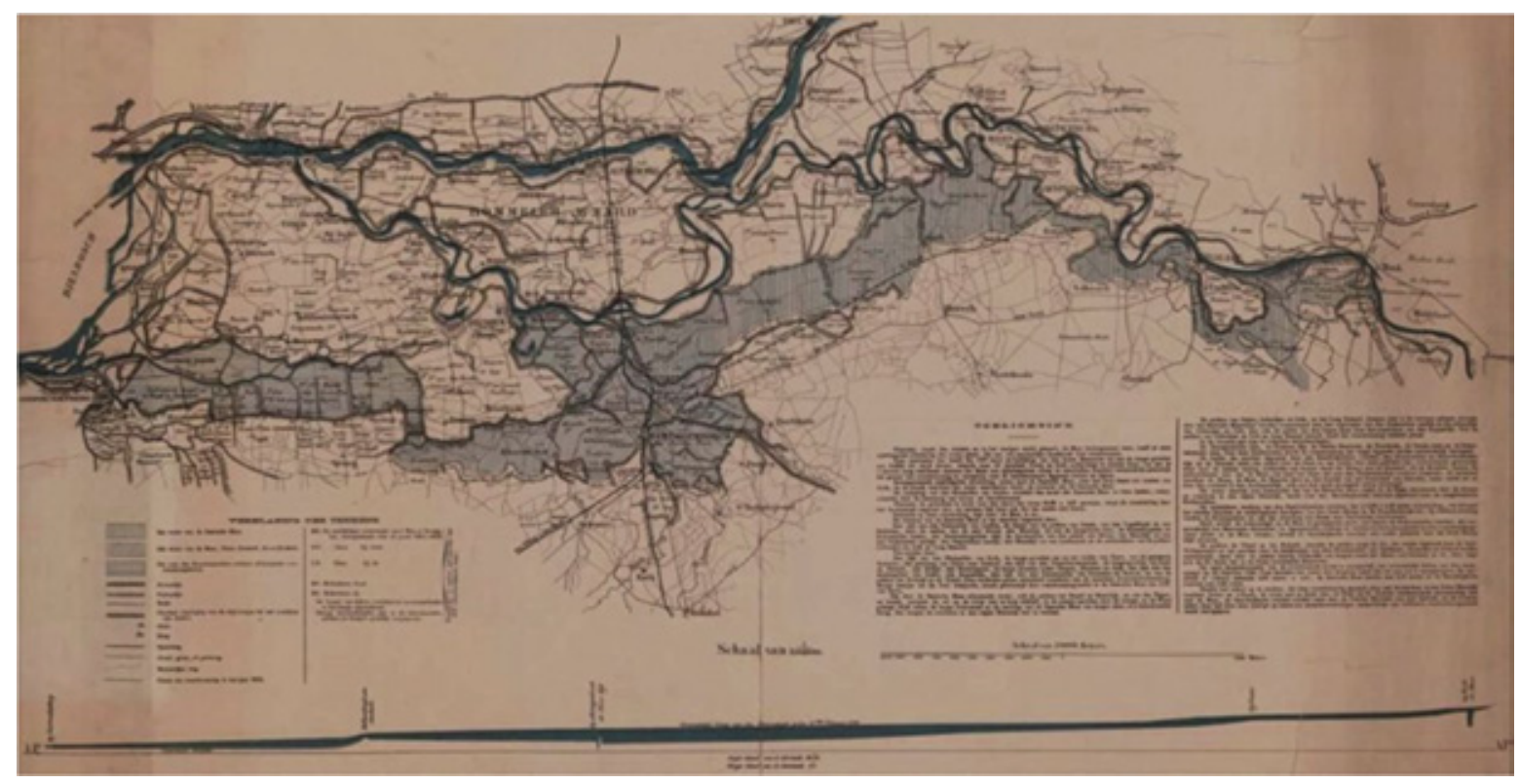

Figuur 2-5 Systeem van overlaten ten zuiden van de Maas. Aan de oostzijde (rechts) de Beersche Overlaat. Via een overlaat in de dijk tussen Linden en Gassel stroomde het water via de $40 \mathrm{~km}$ lange Beersch Maas naar Den Bosch (Bossche Broek). Ten westen van Den Bosch stroomde het water via de Baardwijkse overlaat naar de Amer/Biesbosch. Dorpspolder Escharen werd door dijk gevrijwaard van inundatie. Ook aan de oostzijde van de Lage Raam ligt een dijk die het gebied tussen de Lage Raam en Mill moest vrijhouden van inundatie.

\subsubsection{Substraat}

Voor voorspelling van het beekpatroon en de morfologische dimensies in evenwichtstoestand is het substraat van het bodemprofiel een belangrijke factor. Deze bepaalt de grofheid van het materiaal dat door de beek wordt getransporteerd, evenals de stabiliteit van de oever. Het bedding-/oeversubstraat is afgeleid uit de detailbodemkaart van het gebied (Bijlage 2). Met een overlay-procedure zijn de bodemgegevens gekoppeld aan de waterlopen in de Raamvallei (Figuur 2-6). In de legenda zijn twee aspecten van de bodem weergegeven: de textuur van de bodem en afwijkende aspecten in de bovengrond die van invloed kunnen zijn op de morfologie van de beek, zoals klei en ijzerrijke of humeuze lagen. 


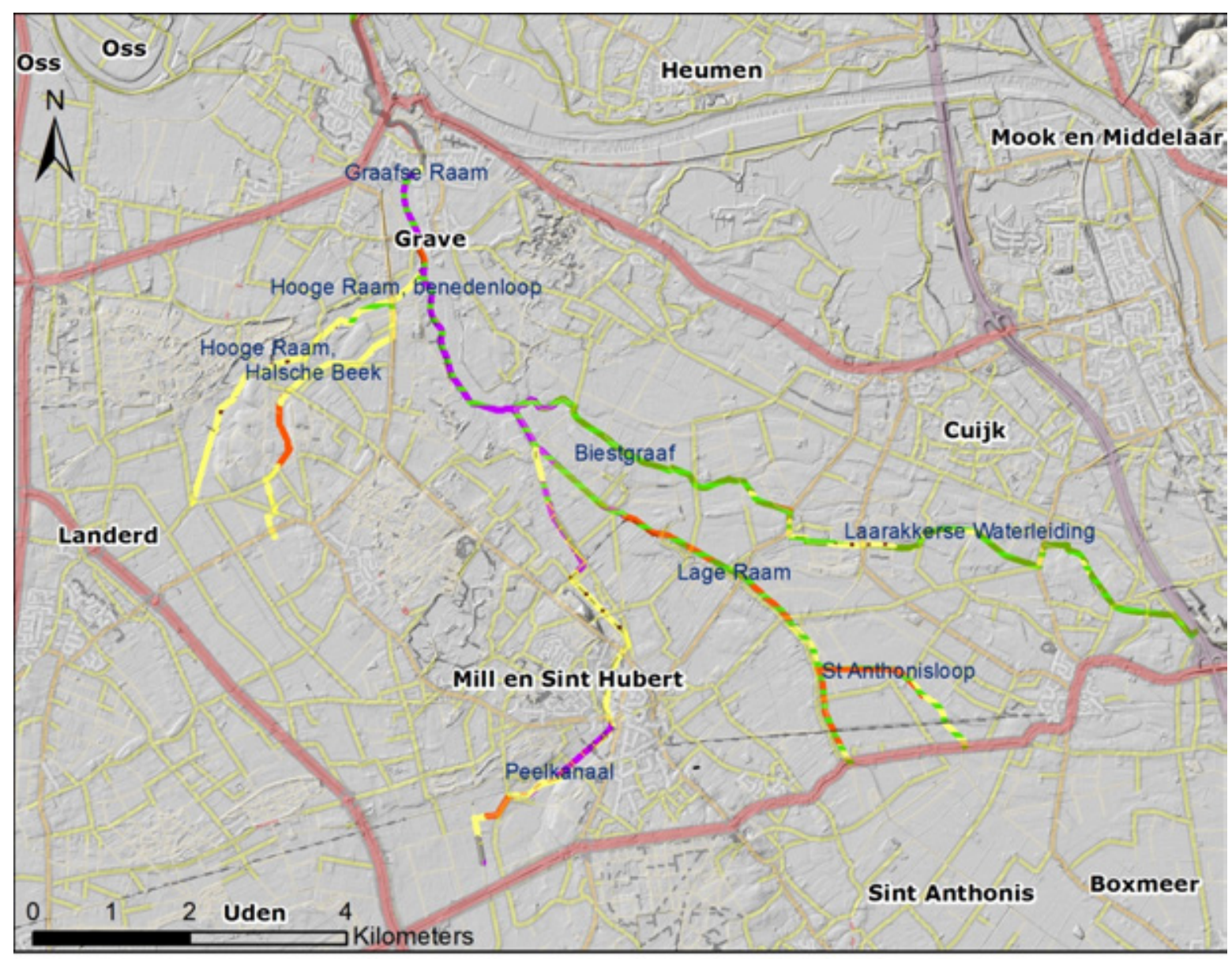

Legenda

\begin{tabular}{|c|c|}
\hline Substraat & Bovengrond \\
\hline Klei & = Klei \\
\hline Matig fijn zand & $:::::$ Humeus zand \\
\hline Matig grof zand & 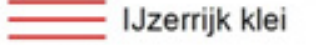 \\
\hline Veen & IJzerrijk zand \\
\hline Water & Zand \\
\hline NB & \\
\hline
\end{tabular}

Figuur 2-6 Substraatkenmerken van de waterlopen in het studiegebied de Raamvallei.

Elke waterloop/traject heeft zijn eigen karakteristieke bedding-/oeversubstraat (Tabel 2-1). Lokaal kunnen er in de praktijk afwijkingen optreden als gevolg van de kaartschaal van de bodemkaart (1:25.000). Matig fijn zand heeft een textuur (M50) van 150-210 $\mu \mathrm{m}$ en matig grof zand een textuur (M50) van 210-420 $\mu \mathrm{m}$. IJzerrijk zand in de bovengrond wordt lokaal aangetroffen in het dal van de Hooge Raam. IJzerrijke klei in de bovengrond komt op basis van de bodemkaart in de Raamvallei niet voor. Tijdens het veldwerk is ijzerrijke klei aangetroffen in het traject van de Graafsche Raam (boring GR2). 
Tabel 2-1 Substraat en bovengrond per waterloop/traject.

\begin{tabular}{|c|c|c|c|}
\hline Waterloop & Traject & Substraat & Bovengrond \\
\hline Graafsche Raam & & veen & Klei (ijzerrijk) \\
\hline Lage raam & Benedenloop & veen & klei \\
\hline Hooge Raam & Benedenloop & matig fijn zand & klei \\
\hline Hooge Raam & Middenloop & matig fijn zand & (humeus) zand \\
\hline Halsche Beek & Middenloop & $\begin{array}{l}\text { matig grof zand } \\
\text { matig fijn zand }\end{array}$ & - \\
\hline
\end{tabular}

\subsubsection{Historische context}

De waterlopen in de Raamvallei komen, met uitzondering van de bovenloop van de Biestgraaf (Laarakkerse waterleiding geheten) en de St. Anthonisloop in hun huidige toestand, voor op de topografische kaart van 1850. In de $17^{\mathrm{e}}$ eeuw wordt de Raam al beschreven als Peelriviertje en ingezet om het gebied rond Grave te inunderen ter verdediging van de stad (http://www.estersheem.nl/water/de-raam).

De Hooge Raam en de Halsche Beek 'ontspringen' in 1850 beide in de Graspeel. De topografie van de Graspeel duidt op gemeenschappelijke weidegronden en uit het toponiem 'gras' valt af te leiden dat het waarschijnlijk om 'grazige' gronden ging, in tegenstelling tot heide op andere delen van de Peel. Ten zuidoosten van het dorp Zeeland was een deel van de Graspeel in 1850 al ontgonnen en waterde via de Hooge Raam af. Het dichte kavelpatroon is een indicatie dat het hier waarschijnlijk om een nat gebied ging. Het geulpatroon van de Hooge Raam was voornamelijk recht, met enkele slingerende trajecten ter hoogte van de Graspeel. Het gedeelte van de Hooge Raam op de flank van de Peelhorst (steil verhang) heeft een opvallend recht geulpatroon. Lokaal komen een paar bochten voor, die niet zonder meer kunnen worden gerelateerd aan een proces van meandering. Beplanting op de oever (bos, singels of houtwallen) kan lokaal de oever stabiliseren, waardoor de tegenovergestelde oever erodeert en er toch een bochtig patroon ontstaat. De Halsche Beek draineerde de oostzijde van de Graspeel en had een vrijwel recht geulpatroon. Uit de kaart valt niet af te leiden of de Hooge Raam en Halsche Beek gestuwd werden.

De Lage Raam ontspringt in 1850 in de Wanroijse Bergen op de Peelhorst. In de ruilverkaveling wordt de Raam naar het zuiden toe doorgetrokken om het Wanroijsche Broek, een kwelgebied op het Maasterras tegen de flank van de Peelhorst, te ontwateren. Het gebied ten oosten van de Lage Raam was in 1850 nog grotendeels onontgonnen en als gemeenschappelijke weidegrond in gebruik. Het gebied ten westen van de Lage Raam was al wel ontgonnen in een dichtpatroon van opstrekkende kavels. Het drainagewater uit dit gebied werd afgevoerd via de Lage Raam. Ter hoogte van de Boerderij Vogelshoek stroomde de Lage Raam samen met een waterloop die, wat de benedenloop betreft, samenvalt met de huidige Biestgraaf. Deze waterloop, een samenloop van andere watergangen, draineerde het deel van het terras ten zuidwesten van de weg van Grave naar Boxmeer. Op de kaart is zichtbaar dat naast de akkers en bewoning op de hogere terrasruggen, de laaggelegen natte restgeulen langzamerhand ook ontgonnen werden.

Vanaf de confluentie van de Lage Raam met de latere Biestgraaf stoomde de Raam verder onder de naam Graafsche Raam. Het gebied waar de Graafsche Raam doorheen stroomt, was tot 1942 een cruciaal onderdeel in de Beersche Overlaat en daarom waarschijnlijk ook nog niet ontgonnen. Het water dat tussen Linden en Gassel over de dijk stroomde, werd via dit 'smalle dal', ten zuiden van Grave, afgevoerd richting Den Bosch. 
Het geulpatroon van de Graafsche Raam, Lage Raam en voorloper(s) van de Biestgraaf was voornamelijk recht. Lokaal komen in vooral de Graafsche Raam en de Biestgraaf enkele slingerende trajecten voor. Gezien het geringe dalverhang, de stabiele oevers en de daarmee samenhangende geringe potenties voor meanderen, zou instromend inundatiewater van de Maas een verklaring kunnen zijn voor lokaal slingerende verloop van de geul. De historische kaart geef geen indicaties voor de aanwezigheid van stuwen in de Graafsche Raam, Lage Raam en Biestgraaf. De huidige stuwen dateren waarschijnlijk uit de ruilverkaveling van de jaren dertig en zestig van de vorige eeuw.

Alle waterlopen in de Raamvallei worden geïnterpreteerd als van oorsprong kunstmatige waterlopen, aangelegd ten behoeve van o.a. de watervoorziening (gebruiksfuncties), drainage van natte kwelgebieden/geïsoleerde broekgebieden en verdediging d.m.v. inundatie. De waterlopen van de Hooge Raam, Halsche beek, Graafse Raam en Biestgraaf zijn voor het grootste deel aangelegd in natuurlijke afwateringsgeulen (dalen en restgeulen), maar doorsnijden ook hogere, natuurlijke terreingedeelten waarbij ze niet de natuurlijk laagte volgen. Binnen de dalen zijn op het AHN patronen en structuren zichtbaar die duiden op andere afwateringsstelsels naast de huidige beekloop (Figuur 2-8). Alleen de Lage raam ligt niet in een natuurlijke laagte. Onder invloed van natuurlijke morfologische processen hebben de waterlopen in de loop der tijd lokaal een natuurlijke morfologie gekregen, wat tot uiting komt in het kaartbeeld van 1850.

In de loop van de $20^{\mathrm{e}}$ eeuw zijn de waterlopen in de Raamvallei in het kader van ruilverkavelingen en verbetering van de waterhuishouding genormaliseerd en rechtgetrokken.

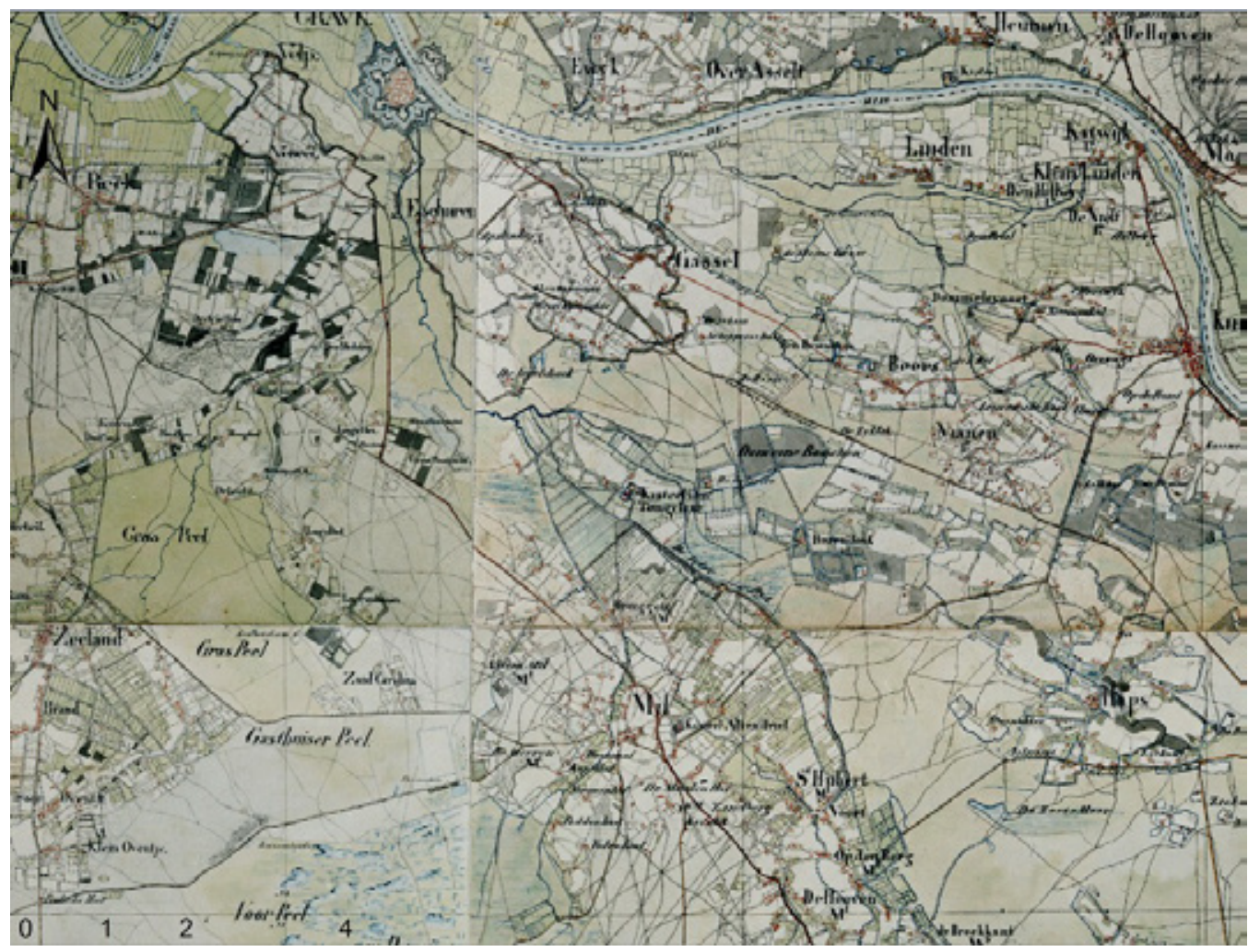

Figuur 2-7 Historische topografische kaart 1850. 


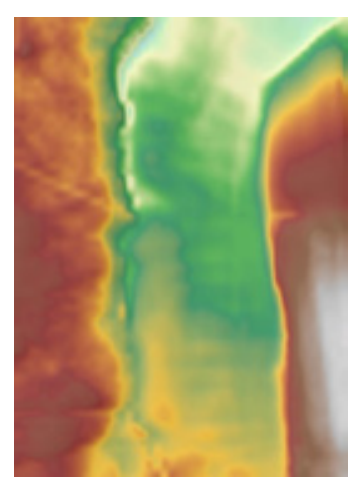

Figuur 2-8 AHN-fragment middenloop van de Halsche Beek. Links de huidige beekloop en rechts patronen van een voormalig verlaten afwateringspatroon.

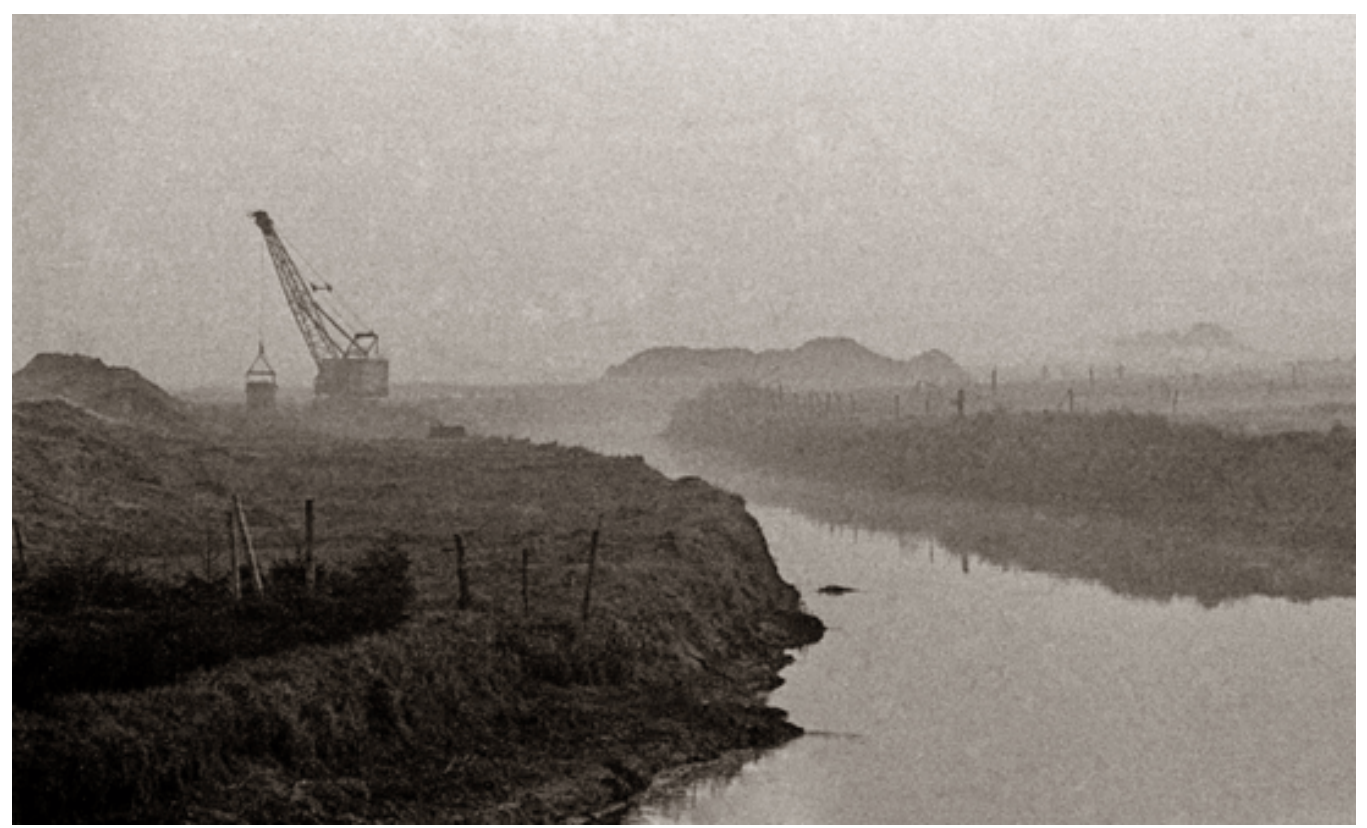

Figuur 2-9 Naar aanleiding van een grote overstroming in het najaar van 1966 wordt de Raam in 1967 verbreed, uitgediept en wat gekanaliseerd (bron: http://www.estersheem.nl/water/de-raam).

\subsubsection{Actueel oppervlakte watersysteem}

Alle waterlopen zijn gestuwd met meerdere stuwen. Hierdoor vindt er geen vrije afstroming van water en sediment plaats, behalve wellicht lokaal in de Hooge Raam en de Halsche Beek vanwege het grote verval. De motor achter natuurlijke morfologische processen in de geul, het transport van sediment door de geul, is daardoor (grotendeels) verstoord. 


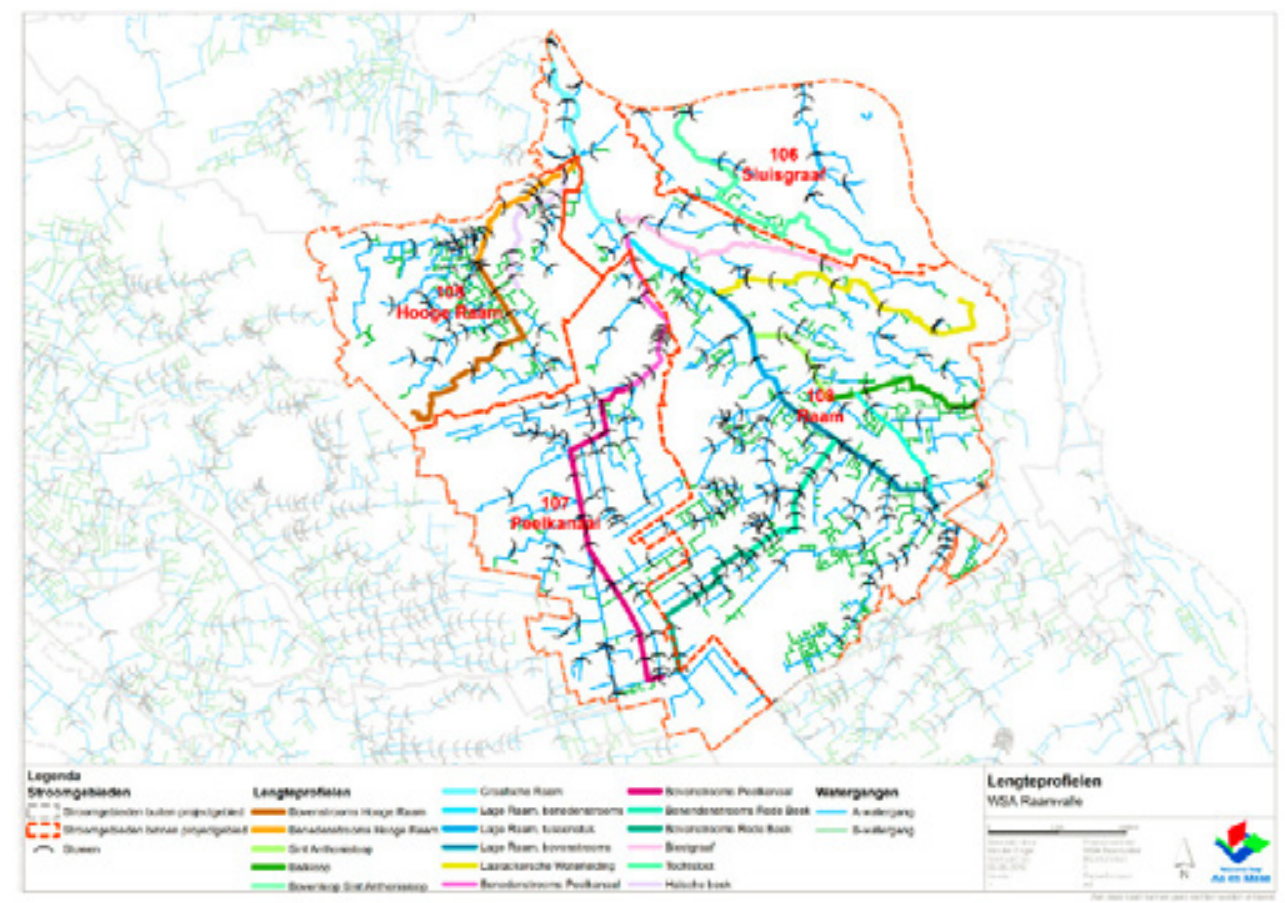

Figuur 2-10 Oppervlaktewatersysteem en stuwen.

\subsubsection{Landschappelijke Bodemkaart}

Om de landschapsecologische context van de beekdalgronden die binnen het hydrologische beïnvloedingsgebied vanuit de beek gelegen zijn te kunnen beschrijven, is gebruikgemaakt van de indeling volgens 'De Landschapsleutel' (Kemmers et al., 2011; Delft et al., 2015). Dit is een werkwijze waarbij op basis van geomorfologie, bodem, overstromingsdynamiek en aanvullende informatie de landschapsecologische positie van een perceel of kaartvlak beoordeeld kan worden. Hiervoor is voor Nederland een hiërarchische indeling gemaakt met op het hoogste niveau 6 Fysisch-Geografische Regio's: Hogere zandgronden (Hz), Laagveengebieden (Lv), Rivierengebied (Ri), Zeekleigebied (Zk), Duin- en kustzandgebied (Du) en Heuvelland $(\mathrm{HI})$. Hierbinnen worden 21 Fysisch-Geografische Secties, 67 Fysisch-Geografische Series en 128 Fysisch-Geografische Typen onderscheiden. Voor het laagste niveau, de FG-typen, is aangegeven welke vegetaties potentieel voor kunnen komen binnen dat type. Deze 'potentiële vegetaties' zijn aangegeven als plantengemeenschap op het niveau van associaties volgens de Vegetatie van Nederland (Schaminée et al., 1995a; Schaminée et al., 1995b; Schaminée et al., 1996; Schaminée et al., 1998; Stortelder et al., 1999). Deze beoordeling is gedaan op basis van het bodemtype (o.a. moedermateriaal en bodemvorming) en de ecohydrologische positie tijdens de bodemvorming (o.a. kwel of infiltratie). Afhankelijk van de actuele abiotische condities (vochttoestand, zuurgraad, voedselrijkdom, overstromingsfrequentie etc.) kan getoetst worden of een standplaats (deel van een perceel, kaartvlak) geschikt is voor een of meer van deze potentiële vegetaties. Hiervoor worden deze condities vergeleken met de abiotische randvoorwaarden uit Waternood (Runhaar en Hennekens, 2014). 


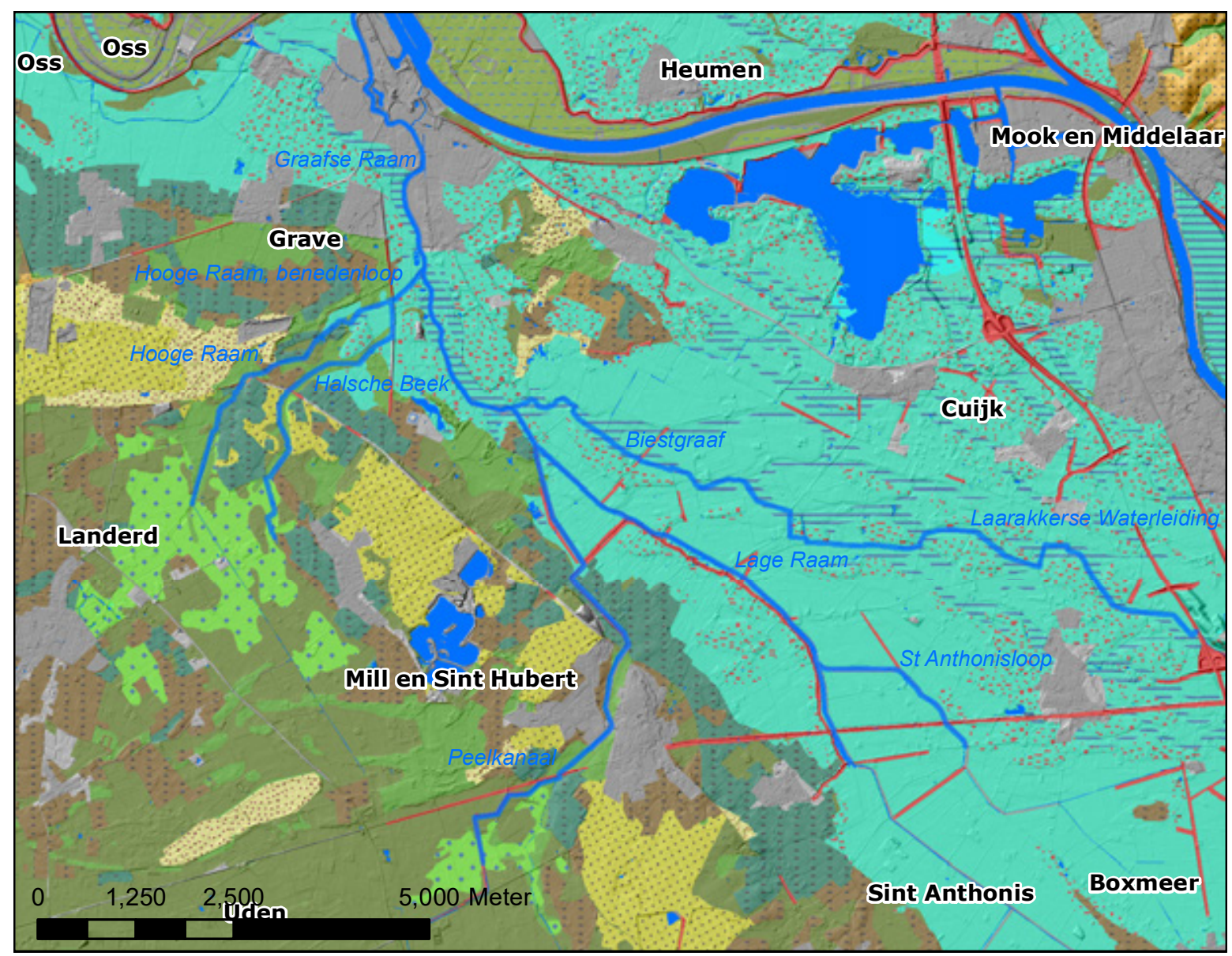

\section{Legenda}

Beeklopen selectie

Dijken

Fysisch-Geografische series Hogere zandgronden

HzG Glaciale gebieden

..... HzGP Puinwaaiers en leemarme stuwwallen

HzS Stuifzandgebieden

HzSD Landduinen

... HzSL Uitgestoven laagten

HzD Dekzandgebieden

$\therefore \mathrm{HzDA}$ Leemarme droge dekzandgebieden

HzDV Vochtige dekzandlaagten

HzB Beekdalen

$\therefore$ HzBB Brongebieden

HzBN Natte en verdroogde beekdalen, inclusief droogdalen

$\mathrm{HzO}$ Oude bouwlanden

: $\mathrm{HzOZ}$ Zwarte eerdgronden

E: HzOB Bruine eerdgronden

E.: HzOL Lage eerdgronden

\section{Fysisch-Geografische series Rivierengebied}

RiL Laaglandrivieren

RiLS Stroombedding Laaglandrivier

RiLW Waarden (binnendijks)

RiT Ingesneden rivieren met terrassen

:-: RiTS Stroombedding ingesneden rivier

RiTP Pleistocene rivierterrassen

— RiTPg Pleistocene rivierterrassen; Geulen

RiTPr Pleistocene rivierterrassen; Ruggen en koppen

Figuur 2-11 Landschappelijke bodemkaart op het niveau van Fysisch-Geografische series.

Door gebruik te maken van geomorfologische en bodemkaarten kan de landschapsecologische indeling van de Landschapsleutel ook ruimtelijk worden weergegeven in een 'Landschappelijke Bodemkaart'. In Figuur 2-11 is voor het studiegebied een dergelijke kaart gemaakt op het niveau van FG-series. Hierbij is gebruikgemaakt van de Geomorfologische Kaart Nederland (zie Figuur 2-1), de detailbodemkaarten voor de ruilverkaveling Land van Cuyk (Kleinsman et al., 1972; Leenders en Zegers, 1974) en Graspeel (Dekkers, 1997) en voor de ontbrekende delen de Bodemkaart van Nederland, schaal 
1 : 50.000 (Bodemkartering 1976). In Bijlage 1 zijn de gebruikte kaarten weergegeven. De op de Peelhorst, enkele pleistocene opduikingen in het Maasdal en de stuwwal bij Mook gelegen gronden worden tot de Hogere zandgronden gerekend, de rest bij het Rivierengebied. Voor de Raamvallei zijn op de Hogere zandgronden de FG-secties 'Dekzandgebieden' (HzD), 'Beekdalen' (HzB) en 'Oude bouwlanden' (HzO) het relevantst, binnen het rivierengebied valt de hele Raamvallei onder de FGsectie 'Ingesneden rivieren met terrassen' (RiT).

\section{Fysisch-Geografische Series}

Als bron voor de Hooge Raam, Halsche Beek en het Peelkanaal kan de FG-serie 'Brongebieden' (HzBB) in Graspeel aangeduid worden. Dit komt overeen met de beekeerdgronden (pZg..) die hier zijn ontstaan onder invloed van ijzerrijke kwel vanaf de hogere delen van de Peelhorst. Neerslagwater dat op de hogere delen (op de Peelhorst) infiltreert, wordt in de ondergrond 'verrijkt' met mineralen die oplossen uit de afzettingen waar het water doorheen stroomt. Het gaat daarbij onder andere om calcium en ijzer. Als dit water in de lagere delen (zoals de Graspeel) als kwelwater weer aan het oppervlak komt, slaan de mineralen, onder invloed van toetredend zuurstof, weer neer waarbij ijzer herkenbaar is aan de roestvlekken in de bodem. Bij een langdurige en sterke aanvoer van ijzerrijk kwelwater kunnen ook zogenaamde 'ijzerconcreties' ofwel 'ijzeroer' gevormd worden.

Beekeerdgronden worden gekenmerkt door een sterk roestige of ijzerrijke minerale eerdlaag (humushoudende bovengrond) en zijn daarmee een goede indicator voor kwel tijdens de bodemvorming. Of dergelijke kwel nog steeds voorkomt, hangt af van de actuele hydrologische situatie. Het voorkomen van beekeerdgronden in de Graspeel is dus een sterke aanwijzing voor de aanwezigheid van kwel in de historische situatie. Vanuit dit kwelgebied vloeide uittredend kwelwater via kleine stroompjes naar de bovenlopen van deze beken. Kwel wordt nog steeds waargenomen (Figuur 2-12), maar wordt nu via diepe sloten afgevoerd.

Vanuit de brongebieden zijn de beekdalen herkenbaar (FG-serie HzBN - Natte en verdroogde beekdalen, inclusief droogdalen). Lokaal stromen de beken door FG-serie 'Vochtige dekzandlaagten' (HzDV); waarschijnlijk betreft dit gegraven trajecten. Langs de flanken van de beekdalen zijn 'Lage eerdgronden' (HzOL) onderscheiden. Dat betreft voormalige beekdalgronden die vanaf de Middeleeuwen zijn opgehoogd om ze geschikt te maken voor akkerbouw. 


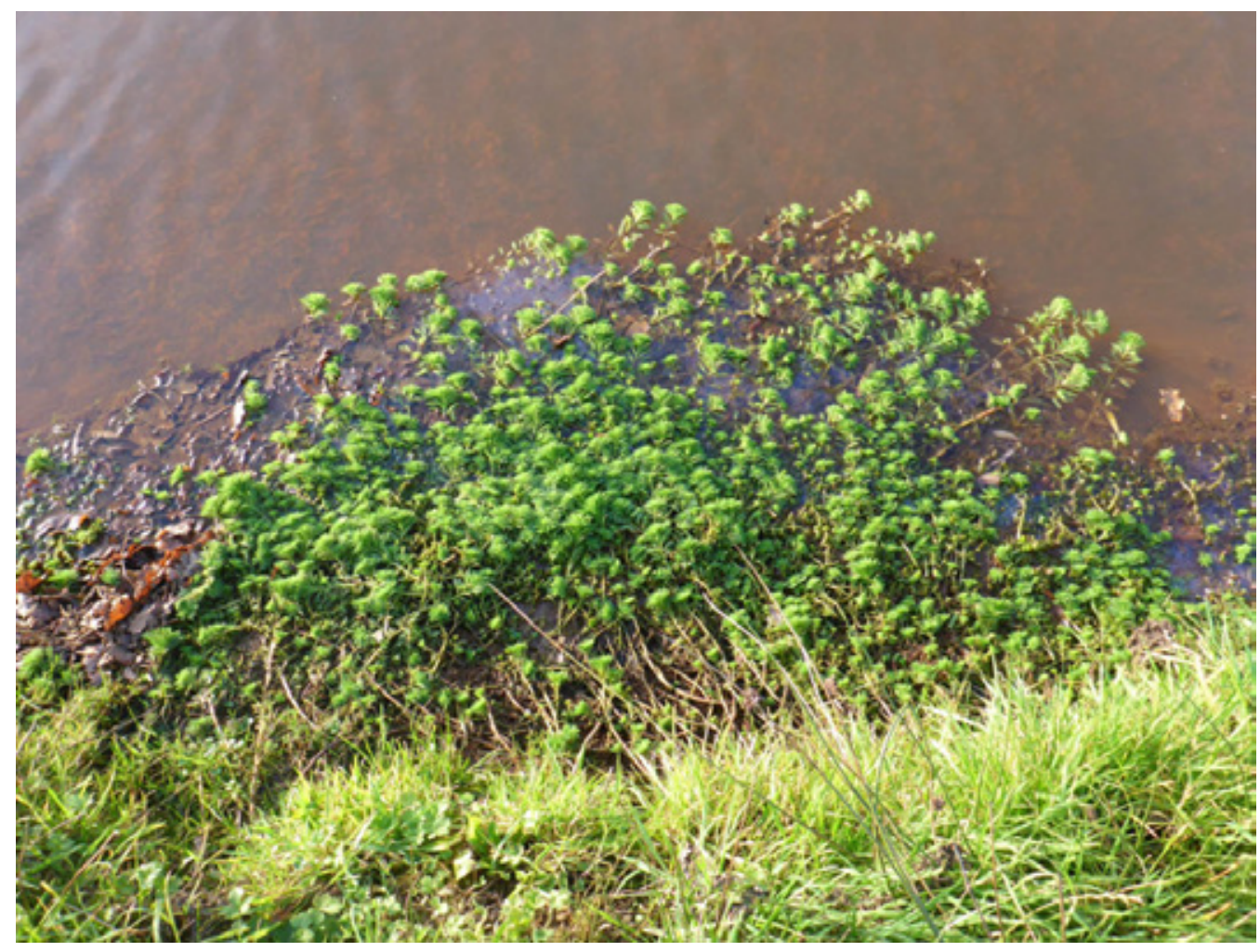

Figuur 2-12 IJzerneerslag op de bodem en kwelfilm tussen de vegetatie in de bovenloop van de Hooge Raam bij de Logtschedijk.

Het lager gelegen deel van de raamvallei dat op het Maasterras ligt, wordt volgens de oorspronkelijke indeling van de Landschapsleutel (Kemmers et al., 2011) gerekend tot de FG-serie 'Pleistocene rivierterrassen' (RiTP). Omdat deze indeling op dit niveau te weinig gedifferentieerd is om goed onderscheid te maken tussen de lagere delen waar de natuurlijke afwatering gebruik van maakt en de hogere delen, zijn binnen deze serie de geulen (RiTPg) en de ruggen en koppen (RiTPr) apart onderscheiden - voor zover dat mogelijk was - op basis van het gebruikte kaartmateriaal. De oorspronkelijke afwatering van het Maasterras zal plaatsgevonden hebben via de geulen. Een belangrijk deel van de huidige waterlopen is gegraven, waarbij ook ruggen en koppen zijn doorsneden.

\section{Fysisch-Geografische Typen}

Op het laagste niveau van de indeling van de Landschapsleutel zijn de beekdalgronden, die binnen het hydrologische beïnvloedingsgebied vanuit de beek gelegen zijn, ingedeeld bij Fysisch-Geografische typen. In de factsheets per beekloop zijn deze op kaart weergegeven in Figuur 3-1, Figuur 3-2, Figuur 3-5 en Figuur 3-6/ De voorkomende FG-typen zijn samengevat in Tabel 2-2. 
Tabel 2-2 Fysisch-Geografische typen in de beekdalgronden van de Raamvallei, gegroepeerd per FG-serie.

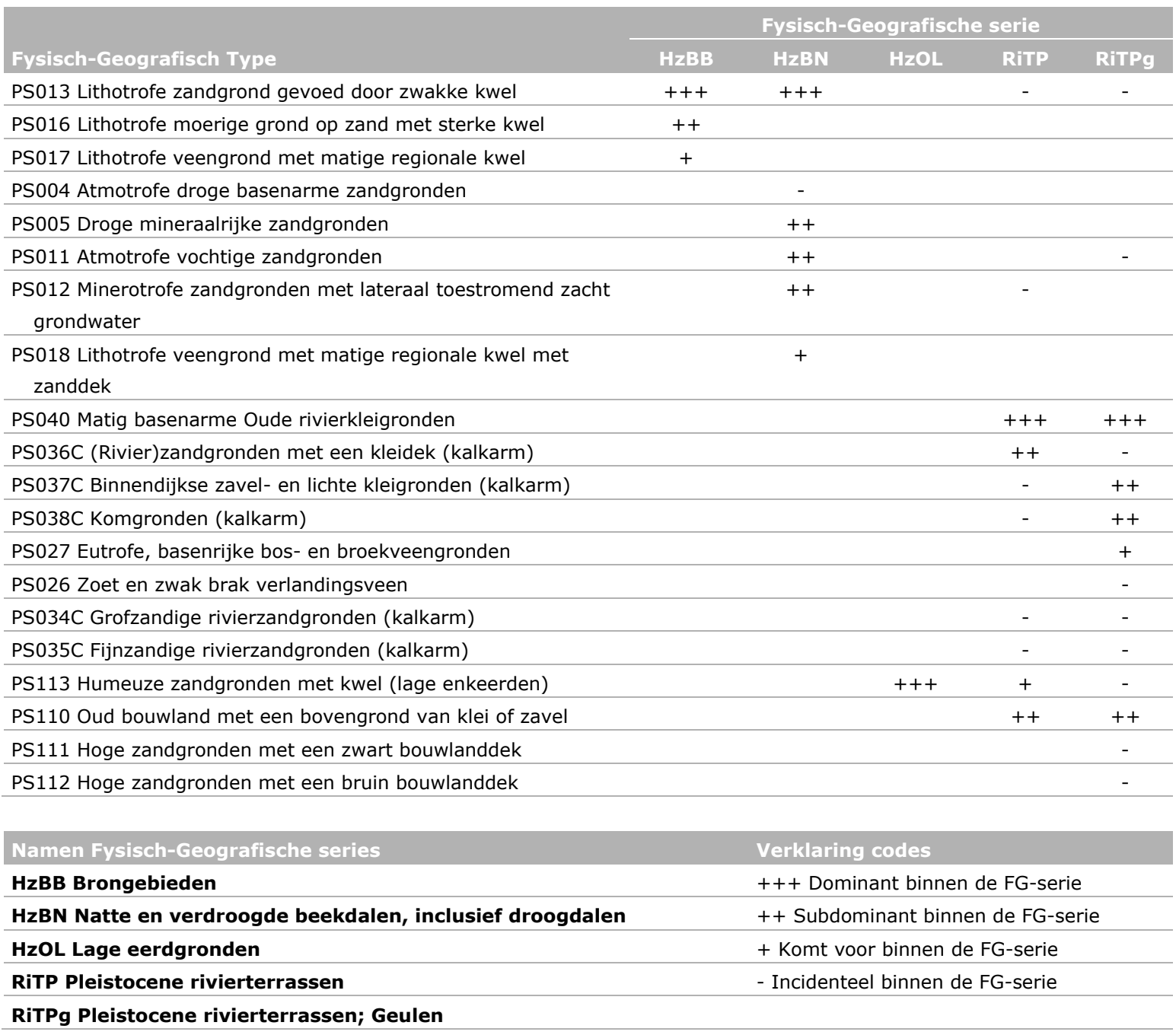

PS013 Lithotrofe zandgrond gevoed door zwakke kwel

Het Fysisch-Geografisch type PS013 'Lithotrofe zandgrond gevoed door zwakke kwel' komt overeen met de bodemeenheid beekeerdgronden (pZg..) en komt voor op locaties waar ijzerhoudende kwel voorkomt in zandig moedermateriaal, of voorkwam tijdens de bodemvorming. Door in het kwelwater opgeloste stoffen als calcium en bicarbonaat wordt de zuurgraad van de bodem gebufferd. Omdat het uittredende water oppervlakkig afstroomt, vindt hierbij geen veenvorming plaats. De vochtige, goed gebufferde bodem heeft een actief bodemleven, waardoor organisch materiaal snel wordt afgebroken en door regenwormen gehomogeniseerd wordt in de bovenste decimeters (Van Delft \& Kemmers, 2002; Van Delft et al., 2006). Hierdoor ontstaat een mesotrofe standplaats voor de natuurlijke vegetatie. 


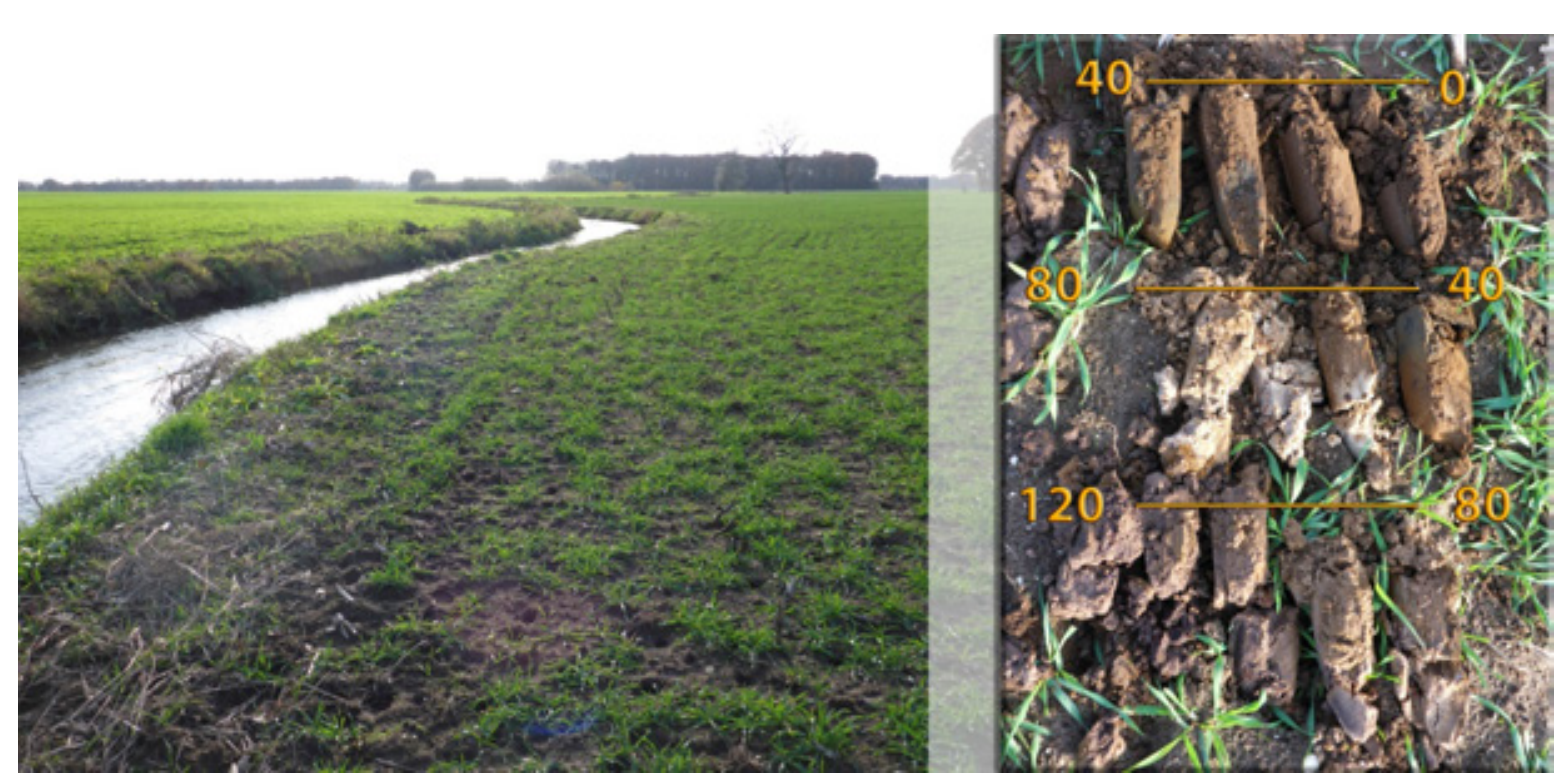

Figuur 2-13 Lithotrofe zandgrond gevoed door zwakke kwel (PS013) langs de Hooge Raam binnen FG-serie HzBN (Natte en verdroogde beekdalen). Rechts het bodemprofiel in boring 4 (locatie HR4 in Figuur ): de boorkernen zijn per $10 \mathrm{~cm}$ uitgelegd, van rechtsboven (0 cm -mv.) tot linksonder (120 cm $-m v$.).

'Lithotrofe zandgrond gevoed door zwakke kwel' (PS013) is het dominante FG-type binnen de FGseries HzBB 'Brongebieden' in de Graspeel en HzBN 'Natte en verdroogde beekdalen, inclusief droogdalen' in de dalen van de Hooge Raam en de Halsche Beek (zie Tabel 2-2 en Figuur 3-2). Als gevolg van diepe ontwatering komt in de meeste gronden met deze eenheid geen kwel meer voor in maaiveld en zijn de grondwaterstanden dieper dan tijdens de bodemvorming, waardoor minder aanvulling van de zuurbuffer plaatsvindt en deze gronden droger en zuurder zijn dan in de referentiesituatie.

PS016 Lithotrofe moerige grond op zand met sterke kwel PS017 Lithotrofe veengrond met matige regionale kwel

In kwelrijke situaties waar de aanvoer van kwelwater zeer groot is en/of het reliëf oppervlakkige afstroming beperkt, ontstaan permanent natte situaties waarin kwelwater op het maaiveld stagneert. Hierdoor wordt het bodemleven beperkt tot bacteriën die zonder zuurstof organisch materiaal kunnen afbreken (anaerobe afbraak). Hierdoor hoopt organisch materiaal zich op en vindt veenvorming plaats. Afhankelijk van de dikte van dit veenpakket worden op de bodemkaart moerige eerdgronden ( $\mathrm{vWz}$, $z W z ;<40 \mathrm{~cm})$ of veengronden $(a V z ;>40 \mathrm{~cm})$ onderscheiden. De moerige eerdgronden rekenen wij bij PS016, de veengronden bij PS017.

In de Raamvallei komen deze FG-typen voor in de bovenloop van het Peelkanaal. Als gevolg van ontwatering zijn deze gronden vaak verdroogd en vindt geen actieve veenvorming meer plaats. Verdroging kan ook leiden tot afbraak van het veen en mineralisatie van de daarin opgeslagen nutriënten (stikstof en fosfaat). 


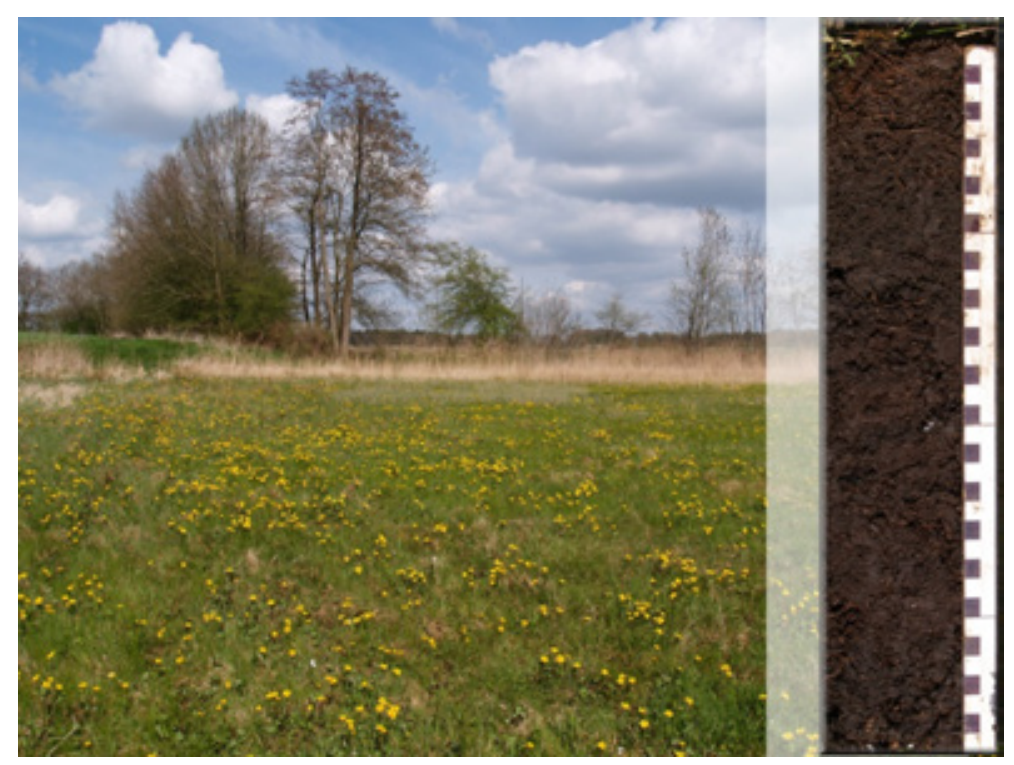

Figuur 2-14 Voorbeeld van een Dotterbloemhooiland op een 'Lithotrofe veengrond met matige regionale kwel' (PS017) in het Reestdal.

\section{PS011 Atmotrofe vochtige zandgronden}

Hoger in de gradiënt binnen de beekdalen, waar geen kwel optreedt, overheerst infiltratie van neerslagwater de bodemvorming. Samen met humuszuren, ijzer en aluminium spoelen hier basische kationen uit, waardoor de zuurbuffer laag is en onder natuurlijke omstandigheden een zure bodem ontstaat. Activiteit van het bodemleven is hier beperkt tot mesofauna (springstaarten, mijten) of tot schimmels (Van Delft et al., 2006). Afbraak van organisch materiaal verloopt traag en er vindt stapeling van organisch materiaal plaats in een strooisellaag of in wortelmatten waaruit nutriënten slechts langzaam beschikbaar komen voor de vegetatie. Het bodemtype komt overeen met de veldpodzolgronden (Hn..) op de bodemkaart. De natuurlijke vegetatie bestaat uit arm bos of heide.

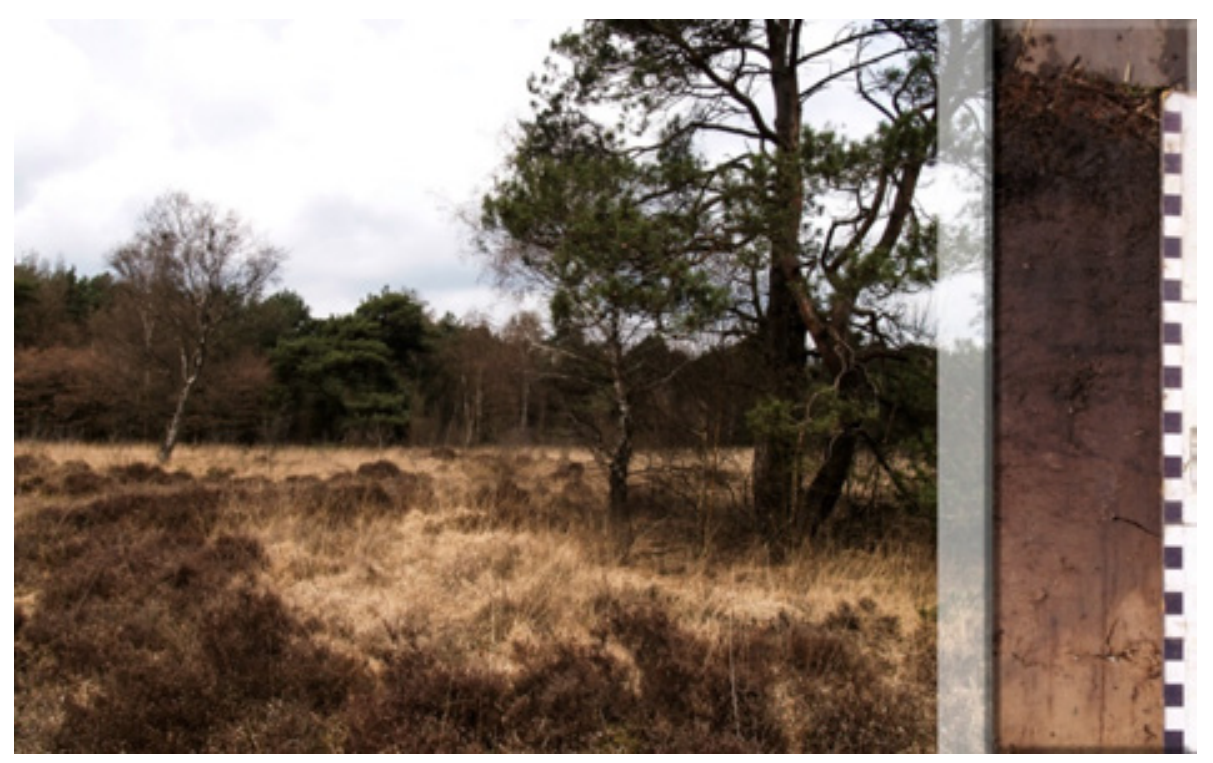

Figuur 2-15 Voorbeeld van een heidevegetatie op een 'Atmotrofe vochtige zandgrond' (PS011) in Groot Zandbrink (Gelderland).

In de Raamvallei wordt dit FG-type aangetroffen langs de flanken van de beekdalen (HzBN) van Hooge Raam en Halsche Beek. 
PS012 Minerotrofe zandgronden met lateraal toestromend zacht grondwater In het overgangsgebied tussen de infiltratiezone en de kwelgebieden in een beekdal vindt vooral horizontale (laterale) grondwaterstroming plaats. Omdat het water over vrij korte afstand verplaatst wordt en niet in aanraking komt met kalkhoudende afzettingen in de ondergrond, bevat het minder ijzer en calcium dan het kwelwater bij PS013, maar het is minder zuur dan het neerslagwater bij PS011. De bodems zijn vochtig en zwak gebufferd, waardoor een vrij actief bodemleven kan voorkomen, maar minder dan bij PS013. Het overeenkomende bodemtype is de gooreerdgrond (pZn..). In de Raamvallei wordt dit FG-type hier en daar aangetroffen in het beekdal van de Hooge Raam.

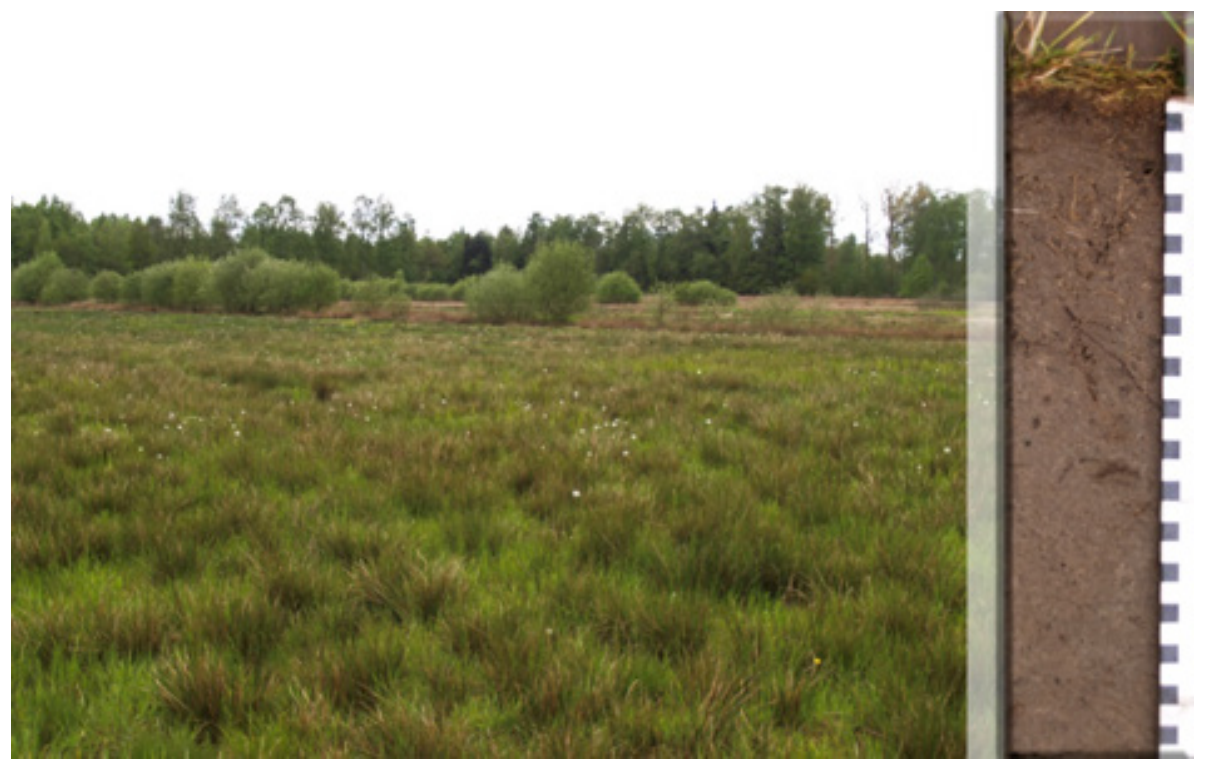

Figuur 2-16 Voorbeeld van een hooiland op een 'Minerotrofe zandgrond met lateraal toestromend zacht grondwater' (PS012) in het Rode Goor bij Oud Turnhout (B).

PS113 Humeuze zandgronden met kwel (lage enkeerden)

In veel beekdalen (vooral in Noord-Brabant) zijn in de Middeleeuwen natte delen van het beekdal opgehoogd om er akkerbouw op te kunnen bedrijven. Dat was nodig vanwege de snel groeiende steden in Noord-Brabant en Vlaanderen (Stiboka 1976; Jongmans et al., 2012). Hierdoor ontstonden de zgn. lage enkeerdgronden (EZg..) die in de systematiek van de Landschapsleutel worden aangeduid als 'Humeuze zandgronden met kwel (lage enkeerden)' (PS113). In de Raamvallei wordt dit FG-type aangetroffen in de beekdalen (HzBN) van de Hooge Raam en Halsche Beek, maar ook op de 'Pleistocene rivierterrassen' (RiTP) langs de Lage Raam, Biestgraaf en Laarakkerse Watergang. 


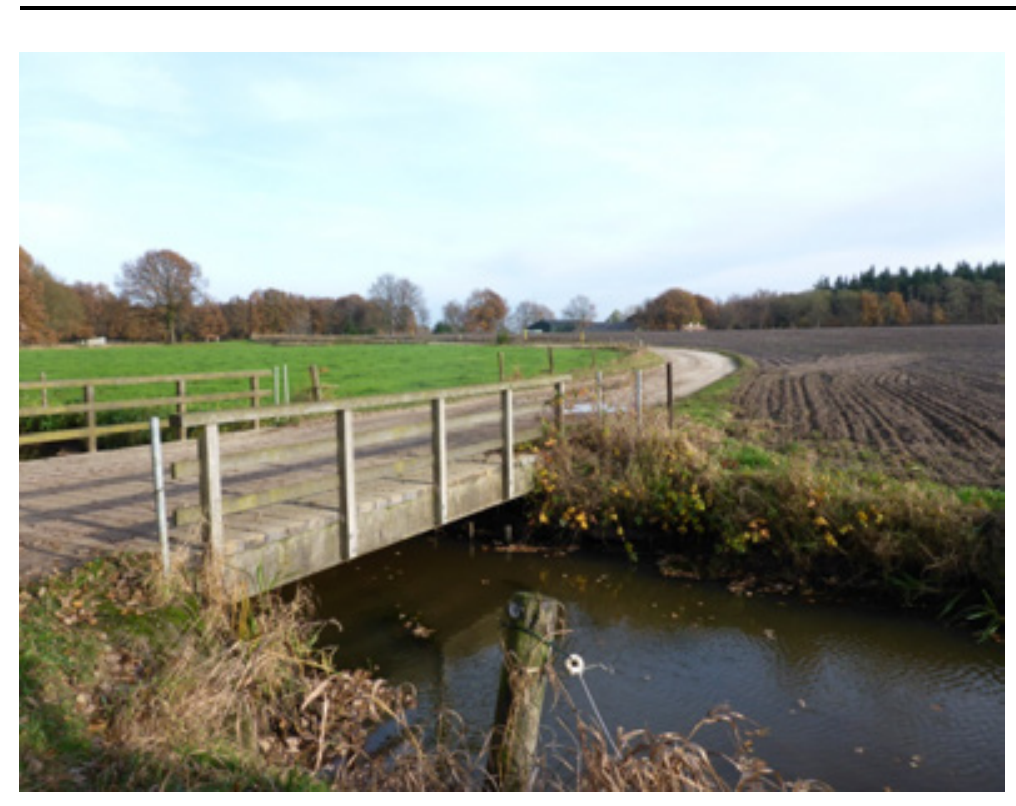

Figuur 2-17 'Humeuze zandgronden met kwel (lage enkeerden)' (PS113) langs de Hooge Raam bij de Zandvoortsestraat.

PS040 Matig basenarme Oude rivierkleigronden

Het belangrijkste FG-type in de pleistocene rivierterrassen (RiTP) zijn de 'Matig basenarme Oude rivierkleigronden' (PS040). Deze bestaan overwegend uit zavel en lichte klei. Omdat het oude kleiafzettingen zijn, zijn zij arm aan basen en hebben daardoor een geringere zuurbuffer dan jonge kleigronden. De Biestgraaf/Laarakkerse Watergang en in mindere mate de Lage Raam volgen van nature de geulen in het pleistocene rivierterras (RiTPg).

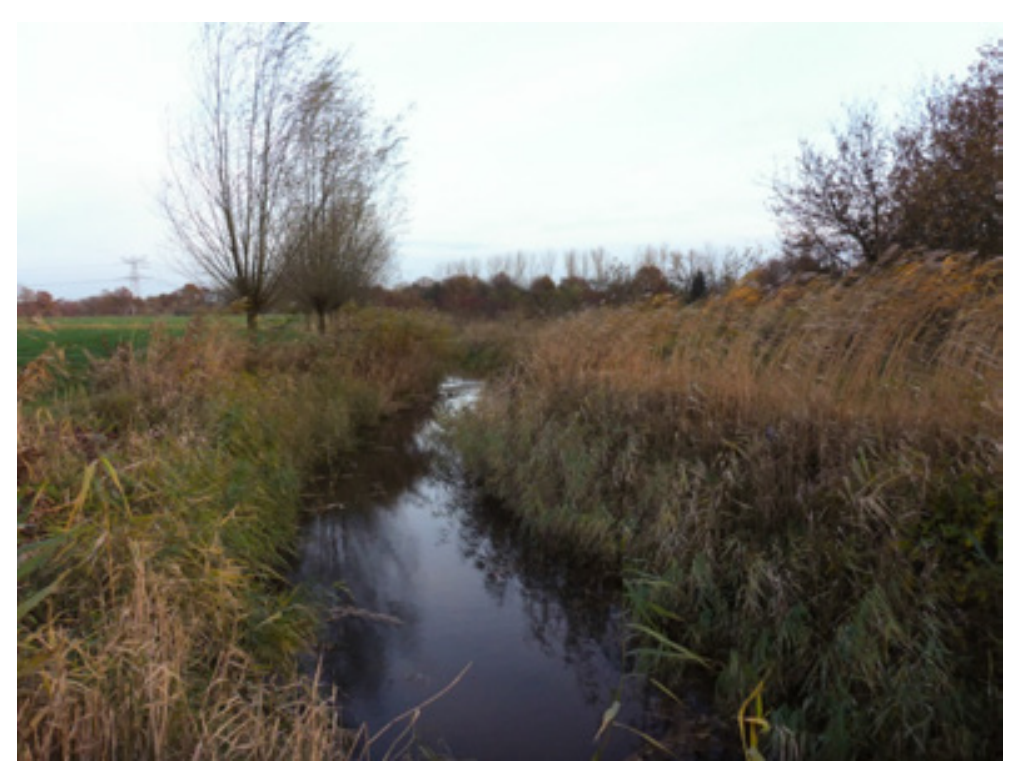

Figuur 2-18 De Biestgraaf/Laarakkerse Waterleiding stroomt grotendeels door 'Matig basenarme Oude rivierkleigronden' (PS040) in de geulen van 'Pleistocene rivierterrassen' (RiTPg).

PS036C (Rivier)zandgronden met een kleidek (kalkarm)

PS034C Grofzandige rivierzandgronden (kalkarm)

PS035C Fijnzandige rivierzandgronden (kalkarm)

Langs de zuidrand van het pleistocene rivierterras (RiTP) is het kleipakket op het onderliggende (grove) zand dunner dan meer naar het noorden of ontbreekt plaatselijk. Het betreft hier resten van een ouder terras dat door erosie deels is verdwenen (zie § 2.1). De grootste oppervlakte wordt 
ingenomen door '(Rivier)zandgronden met een kleidek (Kalkarm)' (PS036C). Waar dit kleidek ontbreekt, wordt - afhankelijk van de zandgrofheid - PS034C of PS035C onderscheiden. Omdat deze zone in de nabijheid van de hoger gelegen Peelhorst ligt en de ondergrond uit (deels grof) zand bestaat, komt hier relatief veel kwel voor. De Lage Raam ontwatert deze kwelzone.

In dit gebied komen ook vrij veel oude bouwlanden voor. Waar deze in een kleibovengrond ontwikkeld zijn, worden zij gerekend tot PS110 'Oud bouwland met een bovengrond van klei of zavel', waar de klei ontbreekt tot PS113 'Humeuze zandgronden met kwel (lage enkeerden)'.

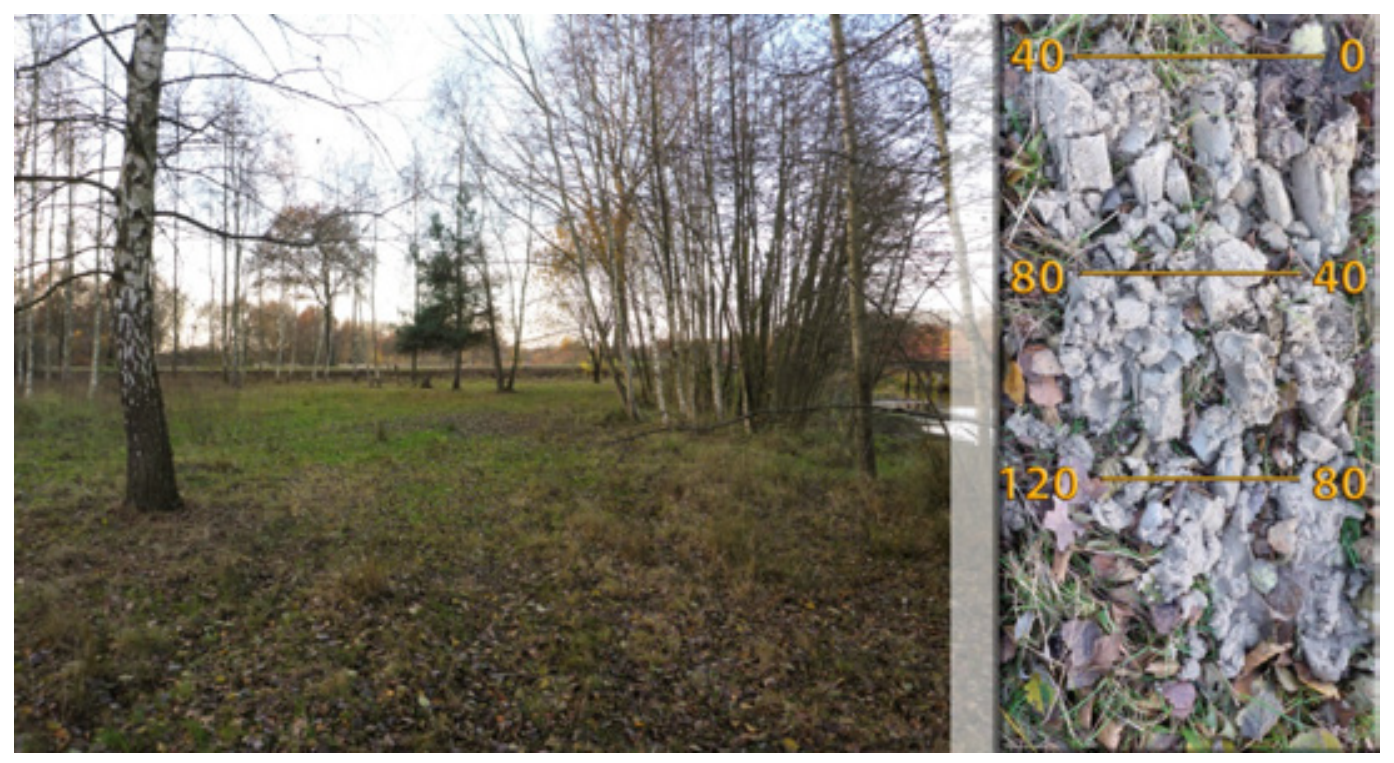

Figuur 2-19 Afgegraven oever van de Lage Raam bij de Vissteeg met 'Fijnzandige rivierzandgronden (kalkarm)' (PS035C). Dit FG-type is hier door afgraven van het kleidek ontstaan uit PS036C '(Rivier)zandgronden met een kleidek (Kalkarm)'. Rechts het bodemprofiel in boring 5 (locatie LR3 in Figuur ): de boorkernen zijn per $10 \mathrm{~cm}$ uitgelegd, van rechtsboven (0 cm -mv.) tot linksonder (120 $c m-m v$.).

PS027 Eutrofe, basenrijke bos- en broekveengronden

Een deel van de oude geulen in het pleistocene rivierterras (RiTPg) is na het verleggen van de rivier verland en dichtgegroeid met veen. In latere fasen van de terrasvorming is hier weer klei overheen afgezet, waardoor deze veengronden een kleidek hebben gekregen ( $k V z$ op de bodemkaart). De Graafse Raam stroomt voor een groot deel door een dergelijke geul. 


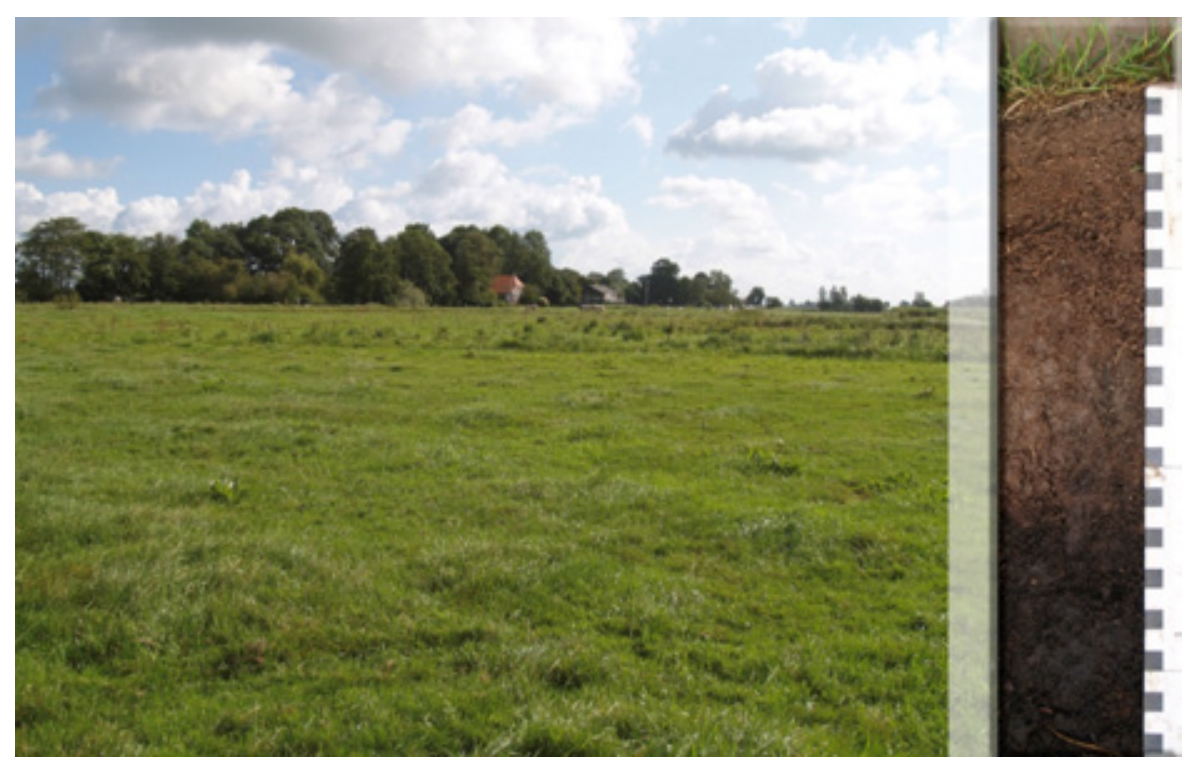

Figuur 2-20 Voorbeeld van een 'Eutrofe, basenrijke bos- en broekveengrond' (PS027) in een veenweidegebied bij Muggenbeet (Ov).

\subsubsection{Potentiële (semi)terrestrische vegetatie}

In de Landschapsleutel (Kemmers et al., 2011) wordt per Fysisch-Geografisch type (in de versie van 2011 'Primaire Standplaats' geheten) een aantal potentiële vegetaties genoemd die op een dergelijke standplaats voor zouden komen, afhankelijk van het beheer en de actuele standplaatscondities, zoals vochttoestand (GVG, GLG, Droogtestress), zuurgraad, voedselrijkdom, overstromingsregime en saliniteit. Hierbij worden vier structuurtypen (successiefasen) onderscheiden die samenhangen met de vegetatieontwikkeling onder invloed van beheer.

Op jonge bodems die recentelijk zijn afgezet of waar de successie is teruggezet door natuurontwikkeling (plaggen, afgraven) zullen zich eerst pioniersoorten vestigen. Dat wordt aangegeven met de vegetatietypen onder de 'pionierfase'. Hierbij kan het voorkomen dat door afgraven een FG-type overgaat in een ander, zoals PS036C '(Rivier)zandgronden met een kleidek (Kalkarm)', dat na afgraven van het kleidek overgaat in PS035C 'Fijnzandige rivierzandgronden (kalkarm)' (zie Figuur 2-19). Dat heeft uiteraard ook gevolgen voor de verdere vegetatieontwikkeling op zo'n locatie.

De ontwikkeling na de pionierfase is afhankelijk van het beheer. Bij een graslandbeheer door maaien en/of intensief begrazen, zal de graslandfase een voorlopige eindfase zijn, zolang het beheer gehandhaafd blijft. Daarvoor zijn de potentiële vegetaties aangeven bij 'graslandfase'. Ook heidevegetaties, die weliswaar geen graslandbeheer kennen, worden tot de graslandfase gerekend. Hier is immers ook altijd actief beheer noodzakelijk om struweel en bosvorming tegen te gaan.

Zonder graslandbeheer zullen de meeste vegetaties via een struweelfase overgaan in een bosfase, tenzij andere factoren als klimaat, zout, extreem hoog grondwater of overstroming de ontwikkeling van struweel of bos onmogelijk maken.

In Bijlage 4 is een overzicht opgenomen van de potentiële vegetaties die volgens de Landschapsleutel verwacht kunnen worden op de in het studiegebied onderscheiden Fysisch-Geografische typen.

Dit overzicht van potentiële vegetaties geeft een denkrichting aan voor de referentiebeelden van de ontwikkeling van de natuur langs de beken. Of deze vegetaties tot ontwikkeling komen en welke dat dan zijn op verschillende locaties, hangt onder andere af van de mate waarin de actuele abiotische condities overeenkomen met de abiotische randvoorwaarden waaraan voldaan moet worden om deze vegetaties tot ontwikkeling te laten komen. Dat is mogelijk door o.a. het grondwaterregime en de voedselrijkdom van de bodems te beoordelen (zie o.a. Van Delft et al., 2012; De Waal \& Van Delft, 
2014; Van Delft, 2014; Van Delft \& De Waal, 2015). Hierbij worden de actuele condities vergeleken met abiotische randvoorwaarden in Waternood (Runhaar \& Hennekens, 2014).

Een dergelijke analyse past niet in het huidige onderzoek, maar kan wel meer inzicht geven in de mogelijkheden en knelpunten voor de natuur langs de beken in de Raamvallei. Vaak vastgestelde knelpunten die ook in de Raamvallei zullen spelen, zijn:

- Te lage grondwaterstanden (GVG en/of GLG): door de drainerende werking van de beken of ontwatering in het algemeen. Dat kan ook tot uiting komen in de factor droogtestress die bepaald wordt door GLG in combinatie met bodemtype.

- Onjuiste overstromingsdynamiek: in benedenlopen van de beken kunnen potentiële vegetaties aangegeven worden die gebaat zijn bij een zekere mate van inundatie, zoals dotterbloemhooilanden (16AB04 - Associatie van Boterbloemen en Waterkruiskruid), terwijl andere vegetaties als Blauwgrasland (16Aa01) weinig inundatie verdraagt.

- Te weinig kwel in maaiveld: kenmerkend voor beekdalen is het voorkomen van kwel. Door allerlei hydrologische veranderingen kan de regionale kwel zijn afgenomen, maar ook waar nog kwel voorkomt, bereikt dat niet altijd het maaiveld, omdat de kwelstroom wordt afgebogen naar diepe sloten die het gebied ontwateren.

- Te hoge voedselrijkdom: als gevolg van (voormalig) landbouwkundig gebruik kunnen in de bodem grote hoeveelheden meststoffen geaccumuleerd zijn, waardoor de voedselrijkdom te groot is voor de potentiële vegetatietypen die vaak aan minder voedselrijke standplaatsen gebonden zijn. Vooral fosfaat kan een langdurig probleem opleveren, omdat dit sterk gebonden wordt in de bodem, waardoor het niet snel zal uitspoelen of anderszins uit de bodem verdwijnen.

\subsection{Beekpatronen, sedimenttransport en bankvorming in de Raamvallei}

In Tabel 2-5 zijn de morfologische karakteristieken van de beeklopen samengevat. De informatie in de kolom 'patroon' is een weergave van de positie in het stabiliteitsdiagram voor geulpatronen (Figuur 2-21). In de kolommen beddingmorfologie en bankvorming staan twee zichtbare kenmerken die samenhangen met transport van beddingmateriaal in de geul. Deze resultaten zijn afgeleid uit de stabiliteitsdiagrammen voor beddingvormen en banktypen (Figuur 2-22). Voor alle waterlopen geldt dat er onder geulvullende omstandigheden in de evenwichtssituatie voldoende stromingsenergie is voor transport van beddingmateriaal $(D 50=218 \mu \mathrm{m})$, zichtbaar in het voorkomen van stroomribbels (Figuur 2-23) op de beddingbodem (veld R in Figuur 2-9). De Hooge Raam-plot in deze diagram op de grens met veld $D$, betekent dat er ook voldoende energie is voor de vorming van lage duinen. Banken in de geul kunnen in de waterlopen in de Raamvallei alleen gevormd worden in de Hooge Raam en in de middenloop van de Halsche Beek (veld C). In de andere waterlopen wordt de bankvorming onderdrukt (veld D). In Figuur 2-24 enFiguur 2-25 wordt van beide bankvormen een voorbeeld gegeven.

Tabel 2-5 en 2-4 zijn de invoergegevens en de resultaten weergegeven van de bepaling van het geultype en de dimensies van de beek in een evenwichtssituatie (zie paragraaf methode 1.3). De uitkomsten van deze analyse moeten gezien worden als indicatief voor de morfologische ontwikkelingsrichting van de onderzochte beken in een geheel natuurlijke setting en gegeven de actuele afvoerdynamiek. Dit geldt met name ook voor berekende dimensies (breedte en diepte) van de geul. Een meer natuurlijke inrichting en beheer van het stroomgebied van de beek beekdalbreed heeft invloed op de afvoerdynamiek van de beek. Het 'flashy' karakter van de afvoer zal worden gedempt, waardoor zich ook een nieuw morfologisch evenwicht zal instellen met andere (kleinere) geuldimensies.

\subsubsection{Geultype}

Het dalverhang, de dominante afvoer en de mediane korrelgrootte van het beddingmateriaal zijn de factoren die het geultype in evenwicht bepalen. Het dalverhang per waterloop is afgeleid van de 
maaiveld-lengteprofielen uit Engel \& Herpen (2016, § 4). Voor de bepaling van de dominante of geulvullende afvoer zijn de debietgegevens in Tabel 8 uit dezelfde rapportage gebruikt. De geulvullende afvoer is gelijkgesteld aan een afvoer bij T1, de gemiddeld jaarlijkse piekafvoer. Deze afvoer wordt gezien als een goede benadering van de geulvullende afvoer die statistisch een herhalingstijd heeft van 1,58 jaar. Voor de mediane korrelgrootteverdeling van het beddingmateriaal (D50) is gebruikgemaakt van de analysegegevens van een beddingmonster uit Hoge Raam (door Eekhout (2014)). De D50 van dit monster is bepaald op $218 \mu \mathrm{m}$. De bodemkaart classificeert de bodem op de locatie van het monster als matig fijn zand (150-210). Door uitspoeling van fijn materiaal door stromend water is de textuur van het beddingsediment vaak iets grover dan die van het omliggende bodemmateriaal. De breedte van de referentiegeul(W) in de formule van het specifieke stromingsvermogen, is gedefinieerd als $W_{r}=4.7 \sqrt{ } Q$, voor geulen met zandig beddingmateriaal.

In de Halsche Beek en de Hooge Raam wordt lokaal grof zand en grindrijkmateriaal aangetroffen. Om te verkennen wat het effect hiervan op het geultype is voor de Hooge Raam en de Halsche Beek, is het specifieke stroomvermogen ook weergegeven bij een textuur van $420 \mu \mathrm{m}$ (bovengrens van de textuurklasse matig grof zand; $210-420 \mu \mathrm{m}$ ).

Tabel 2-3 Morfologische kengetallen van de waterlopen in de Raamvallei.

\begin{tabular}{|c|c|c|c|c|c|c|}
\hline \multirow[t]{2}{*}{ Waterloop } & Traject & $\begin{array}{c}\text { Dal- } \\
\text { verhang }\end{array}$ & $\begin{array}{l}\text { Bedding- } \\
\text { verhang }\end{array}$ & $Q_{b f}(T 1)$ & $\omega p v$ & D50 \\
\hline & & $(\mathrm{m} / \mathrm{m})$ & $(\mathrm{m} / \mathrm{km})$ & (m³/sec.) & $\mathrm{W} / \mathrm{m}^{2}$ & $(\mathrm{~m})$ \\
\hline \multicolumn{2}{|l|}{ Graafsche Raam } & 0,00020 & 0,065 & 11,151 & 1,391197 & 0,000218 \\
\hline Lage raam & Benedenloop & 0,00028 & 0,43 & $4,500^{1}$ & 1,237274 & 0,000218 \\
\hline Lage raam & Middenloop & 0,00028 & 0,45 & 2,308 & 0,886090 & 0,000218 \\
\hline \multicolumn{2}{|l|}{ Biestgraaf } & 0,00032 & 0,35 & 1,143 & 0,712648 & 0,000218 \\
\hline \multicolumn{2}{|l|}{ Hooge Raam² } & 0,00175 & 1,8 & 1,801 & 4,892114 & 0,000218 \\
\hline Hooge Raam & Middenloop & 0,00175 & 1,8 & 1,604 & 4,616809 & 0,000218 \\
\hline Halsche Beek & Middenloop & 0,00390 & 1,7 & 0,197 & 3,605782 & 0,000218 \\
\hline Halsche Beek & Benedenloop & 0,00110 & 1,7 & 0,197 & 1,017015 & 0,000218 \\
\hline St. Anthonis-loop & Benedenloop & 0,00035 & 0,3 & 4,905 & 1,614690 & 0,000218 \\
\hline \multicolumn{7}{|c|}{1 Mondelinge mededeling P. van Santen. } \\
\hline \multicolumn{7}{|c|}{ De Hooge Raam heeft over het grootste deel van de lengte een dalverhang van $1,75 \mathrm{~m} / \mathrm{km}$. De bovenloop van de Hooge Raam (Graspeelloop) } \\
\hline \multicolumn{7}{|c|}{ heeft een verhang van ca. 0,7 m/km en ook de benedenloop, daar waar de Hooge Raam uitmondt in de Graafsche Raam, is veel vlakker. } \\
\hline
\end{tabular}

Van de waterlopen in de Raamvallei vallen de Hooge Raam en het deel van de Halsche Beek met een dalverhang van 3,9 $\mathrm{m} / \mathrm{km}$ in het stabiliteitsdiagram (Figuur 2-21) in het bereik van de meanderende geulen met banken (scrolls). Door het proces van aanwas in de binnenbocht van de geul en erosie van de buitenbocht te verplaatsen, 'meanderen' de bochten door het landschap. De Graafsche Raam, de Lage Raam, de Biestgraaf en de St. Anthonisloop vallen in het stabiliteitsdiagram binnen het bereik van de lateraal stabiele geulen, geulen met weinig stromingsenergie die in de loop van de tijd weinig morfologische veranderingen ondergaan.

Voor de Hooge Raam en de Halsche Beek is in figuur 2-210ok weergegeven wat het effect is van grofzandig beddingmateriaal op de geulmorfologie. De stromingsenergie van de Hooge Raam is voldoende om ook in de situatie van grof zandig beddingmateriaal binnen het bereik van meanderende geulen met banken te vallen. De Halsche Beek beweegt zich naar de grens met het lateraal stabiele bereik in de figuur. Dat betekent dat naarmate het beddingmateriaal de Halsche Beek grover wordt, dit zal leiden tot een stabieler geultype. 


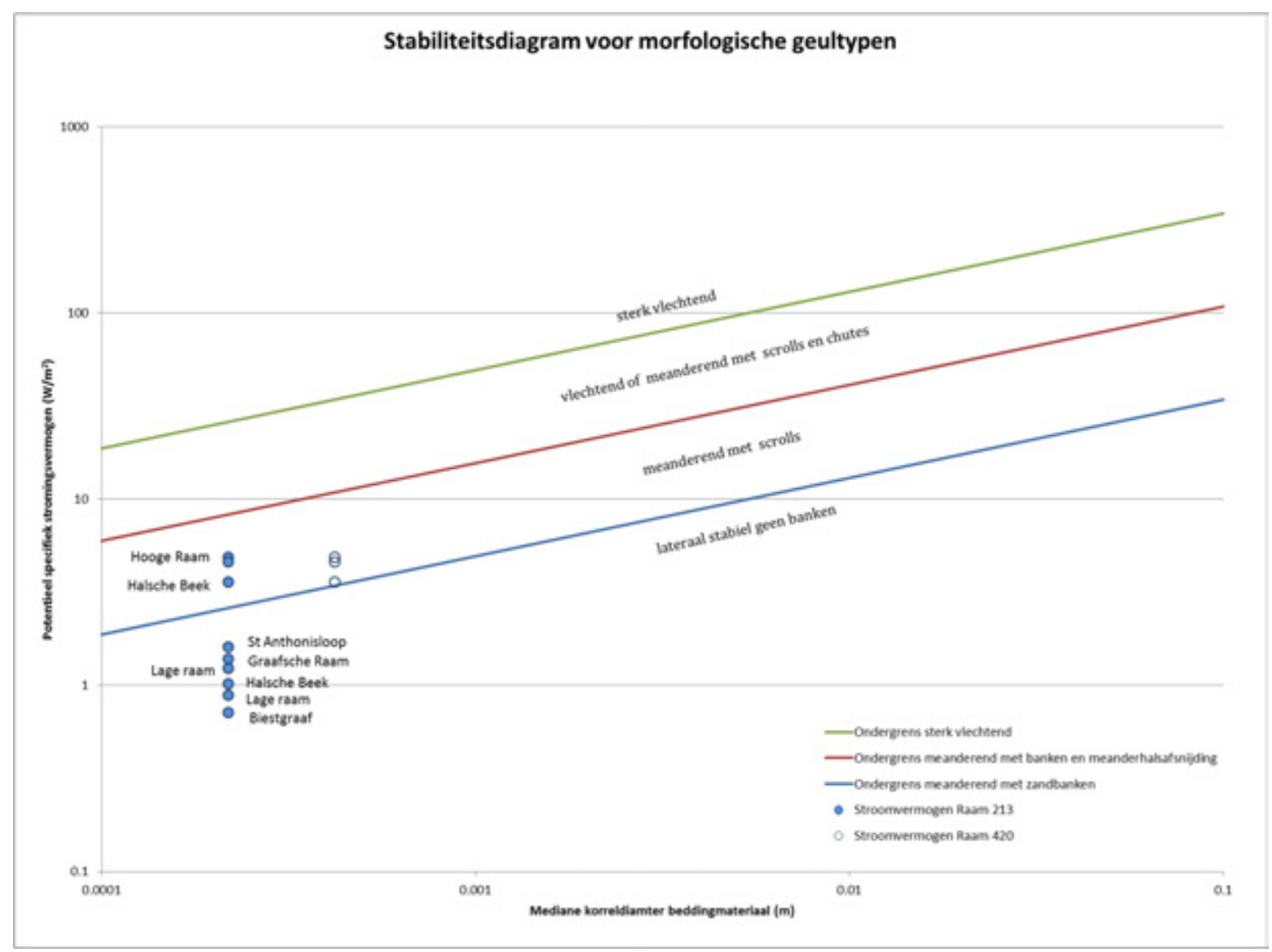

Figuur 2-21 Voorspelling geulpatroon waterlopen Raamvallei bij een mediane korrelgrootte van het beddingsediment van $218 \mu \mathrm{m}$. Voor de Hooge Raam en de Lage Raam zijn de posities bepaald voor twee afvoeren, en voor de Halsche Beek voor twee dalverhanglijnen. Voor de Hooge Raam en de Halsche Beek zijn ook de posities weergegeven bij een mediane korrelgrootte van het beddingsediment van $420 \mu \mathrm{m}$.

\subsubsection{Geulbreedte en geuldiepte in een evenwichtssituatie}

In Tabel 2-4 is een inschatting gegeven van de geulbreedte en -diepte in een morfologische evenwichtssituatie, berekend op basis van de dominante afvoer ( $\S 1.3$ ). De geulbreedte is gedefinieerd als de breedte van de geul bij een geulvullende afvoer, en is daarmee gelijk aan de bovenbreedte van de geul. In de berekening van de geulbreedte is rekening gehouden met de stabiliteit van het oevermateriaal. Voor de geulen in zandig materiaal is een andere waarde voor coëfficiënt a gehanteerd dan in de geulen met veen en/of klei in de oever. Voor de beken met een zandige bedding en weinig cohesieve oevers (Hooge Raam, Halsche Beek en St. Anthonisloop) is de waarde van coëfficiënt a gesteld op 5 en voor de Graafsche Raam, Lage Raam en Biestgraaf, beken met een zandbedding met veen of kleiig sediment in de oevers op 4 ( $\S 1.3$ ). De geuldiepte is berekend met de formule van Brownli ( $\S 1.3$ ) en geldt voor de berekende evenwichtsbreedte. De laatste twee kolommen van Tabel 2-4 geven de breedte-diepteverhouding (W/D) en de Shields-parameter $(\theta)$ weer. De Shields-parameter beschrijft de verhouding tussen de hydraulische kracht van het water en de weerstand van het sediment. Als een kritische waarde, afhankelijk van de korreldiameter van het beddingsediment, wordt overschreden, komt het beddingsediment in beweging (Makaske en Maas, 2015, pag.73). 
Tabel 2-4 Geulbreedte en geuldiepte in een evenwichtssituatie.

\begin{tabular}{|c|c|c|c|c|c|c|c|}
\hline Beekloop & Traject & $\begin{array}{c}\text { Qbf (T1) } \\
\left(\mathrm{m}^{3} / \mathrm{sec} .\right)\end{array}$ & a & $\begin{array}{c}\text { Breedte (W) } \\
(\mathrm{m})\end{array}$ & $\begin{array}{c}\text { Diepte (D) } \\
\text { (m) }\end{array}$ & $\begin{array}{l}\text { W/D } \\
()\end{array}$ & $\theta$ \\
\hline Graafsche Raam & & 11,151 & 4 & 13,4 & 1,34 & 10,0 & 0,7 \\
\hline Lage raam & Middenloop & 2,308 & 4 & 6,1 & 0,73 & 8,3 & 0,6 \\
\hline Biestgraaf & & 1,143 & 4 & 4,3 & 0,56 & 7,6 & 0,5 \\
\hline Hooge Raam & Middenloop & 1,604 & 5 & 6,3 & 0,40 & 15,9 & 1,9 \\
\hline Halsche Beek & Middenloop & 0,197 & 5 & 2,2 & 0,15 & 14,7 & 1,6 \\
\hline Halsche Beek & Benedenloop & 0,197 & 5 & 2,2 & 0,20 & 11,1 & 0,6 \\
\hline St. Anthonisloop & Benedenloop & 4,905 & 5 & 11,1 & 0,77 & 14,4 & 0,7 \\
\hline
\end{tabular}

\subsubsection{Beddingmorfologie en bankvorming}

In Tabel 2-5 zijn de morfologische karakteristieken van de beeklopen samengevat. De informatie in de kolom 'patroon' is een weergave van de positie in het stabiliteitsdiagram voor geulpatronen (Figuur 2-21). In de kolommen beddingmorfologie en bankvorming staan twee zichtbare kenmerken die samenhangen met transport van beddingmateriaal in de geul. Deze resultaten zijn afgeleid uit de stabiliteitsdiagrammen voor beddingvormen en banktypen (Figuur 2-22). Voor alle waterlopen geldt dat er onder geulvullende omstandigheden in de evenwichtssituatie voldoende stromingsenergie is voor transport van beddingmateriaal ( $550=218 \mu \mathrm{m})$, zichtbaar in het voorkomen van stroomribbels (Figuur 2-23) op de beddingbodem (veld R in Figuur 2-9). De Hooge Raam-plot in deze diagram op de grens met veld $D$, betekent dat er ook voldoende energie is voor de vorming van lage duinen. Banken in de geul kunnen in de waterlopen in de Raamvallei alleen gevormd worden in de Hooge Raam en in de middenloop van de Halsche Beek (veld C). In de andere waterlopen wordt de bankvorming onderdrukt (veld D). In Figuur 2-24 enFiguur 2-25 wordt van beide bankvormen een voorbeeld gegeven.

Tabel 2-5 Morfologische karakteristieken waterlopen Raamvallei.

\begin{tabular}{lllll}
$\begin{array}{l}\text { Beekloop } \\
\text { Graafsche Raam }\end{array}$ & Traject & Patroon & beddingmorfologie & bankvorming \\
\hline Lage raam & Benedenloop & lateraal stabiel & stroomribbels & bankvorming onderdrukt \\
\hline Lage raam & Middenloop & lateraal stabiel & stroomribbels & bankvorming onderdrukt \\
\hline Biestgraaf & & lateraal stabiel & stroomribbels & bankvorming onderdrukt \\
\hline Hooge Raam & Middenloop & meanderend met scrolls & stroomribbels/duinen & plaatsvaste kronkelwaardbanken \\
\hline Hooge Raam & Middenloop & meanderend met scrolls & stroomribbels/duinen & plaatsvaste kronkelwaardbanken \\
\hline Halsche Beek & Middenloop & meanderend met scrolls & stroomribbels & plaatsvaste kronkelwaardbanken \\
\hline Halsche Beek & Benedenloop & meanderend met scrolls & stroomribbels & bankvorming onderdrukt \\
\hline St. Anthonis-loop & Benedenloop & lateraal stabiel & stroomribbels & bankvorming onderdrukt \\
\hline
\end{tabular}



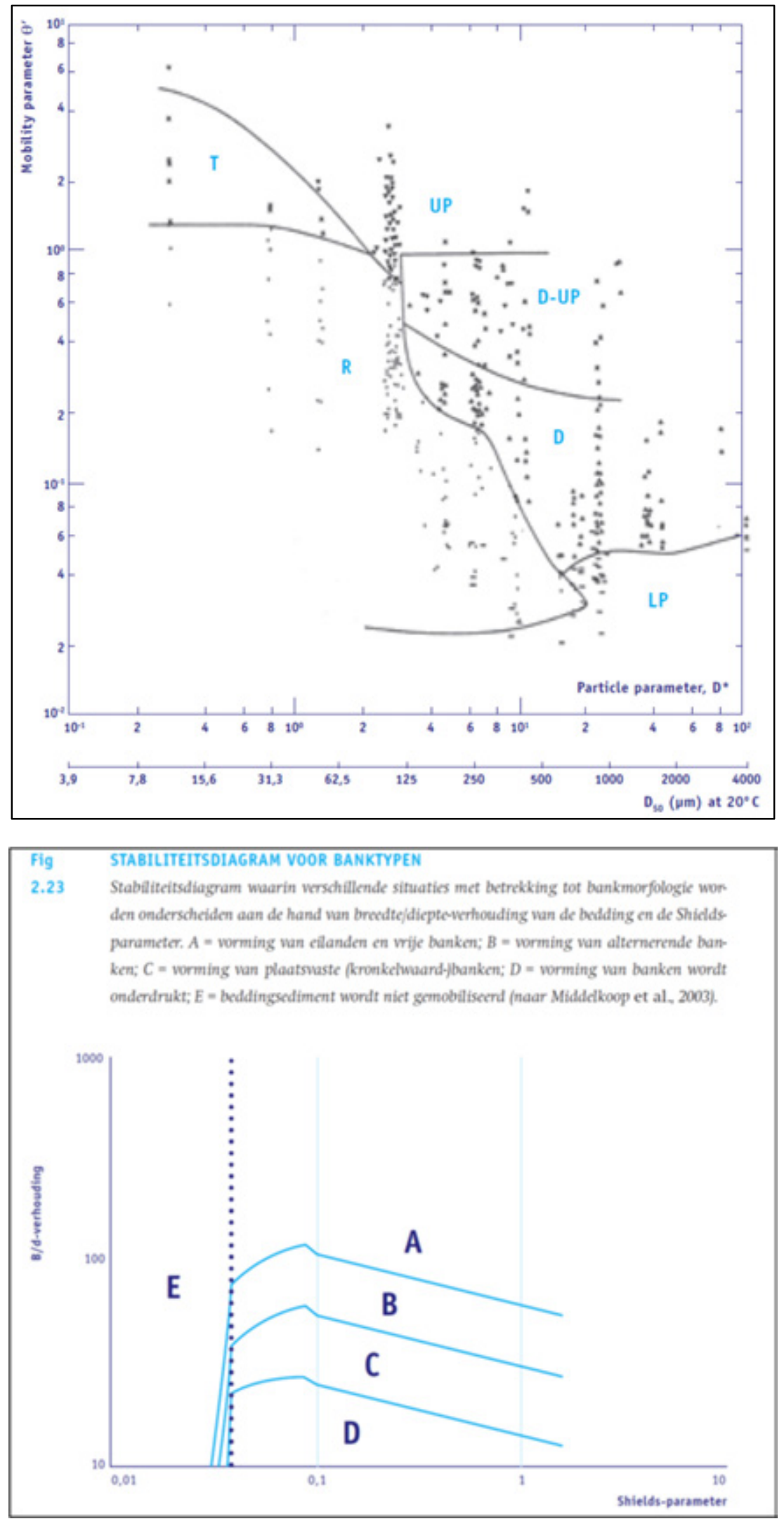

Figuur 2-22 Stabiliteitsdiagram voor beddingvormen (boven) en banktypen (onder). Uit: Handboek geomorfologisch beekherstel, pag. 77-80 (Makaske en Maas, 2014). 


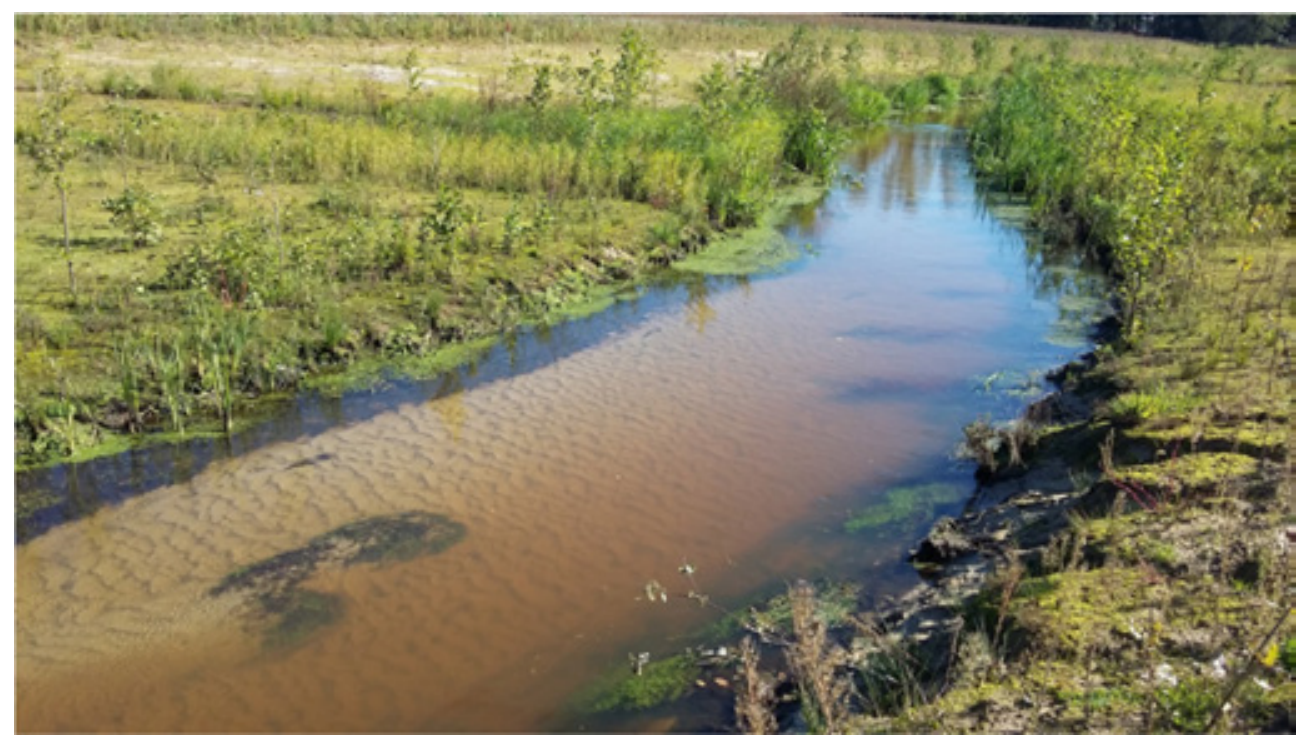

Figuur 2-23 Stroomribbels op een vlakke zandbedding (Lunterse Beek).

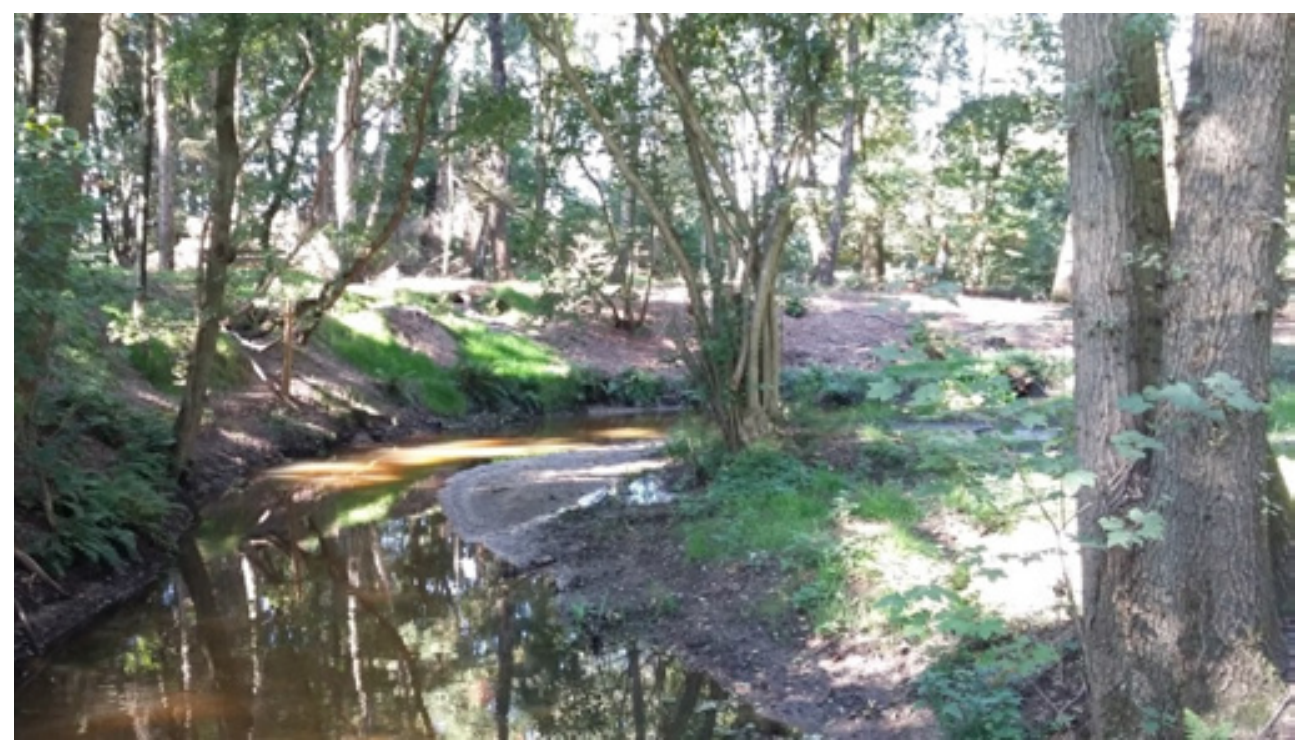

Figuur 2-24 Onderdrukte bankvorming (type D) in de binnenbocht van een beek (Lunterse Beek).

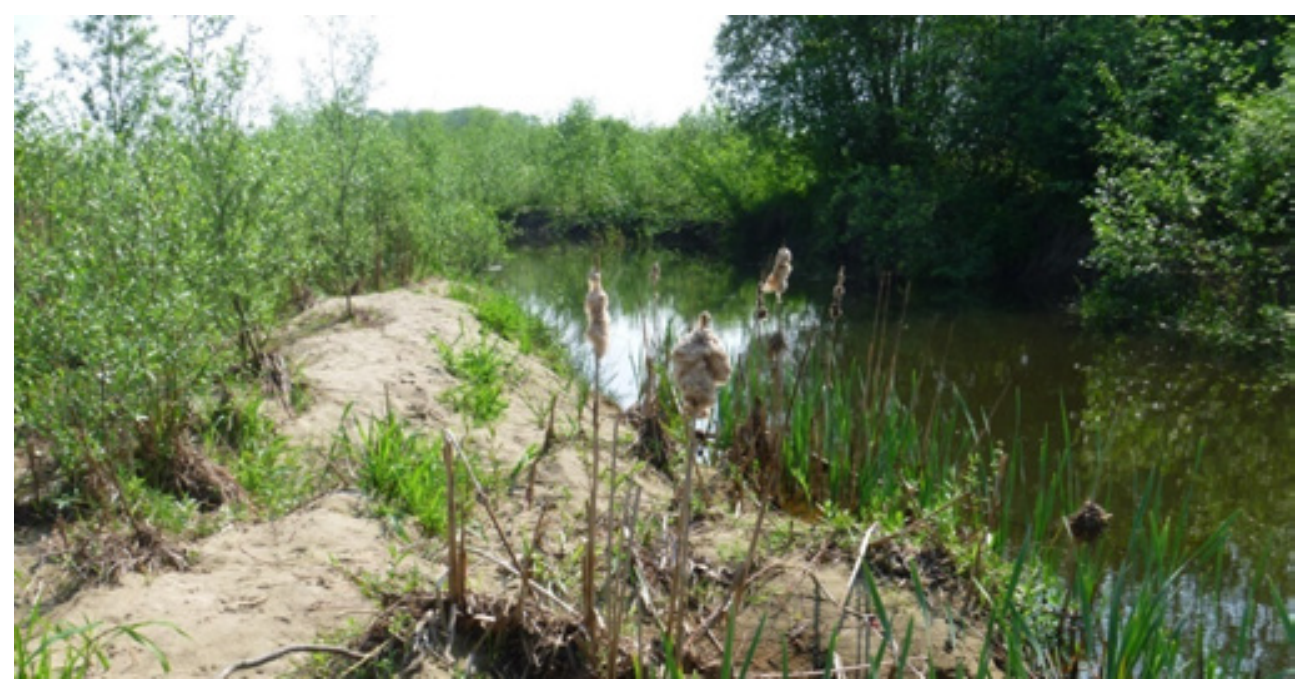

Figuur 2-25 Plaatsvaste/alternerende banken (resp. type C en B) langs de Groenlose Slinge. 


\section{Factsheets voor de beeklopen in de Raamvallei}

In dit hoofdstuk wordt voor elk van de vijf beeklopen die we hebben geanalyseerd in de Raamvallei op beknopte wijze de belangrijkste informatie gegeven. Per beekloop wordt ten eerste een kaart gepresenteerd met de relevante Fysische-Geografische typen voor het betreffende beeksysteem, vervolgens wordt een tabel met een overzicht van de belangrijkste systeemkenmerken gegeven en ten slotte een tabel met onze waarnemingen in het veld. Het geheel wordt geïllustreerd met figuren en foto's. De Fysische-Geografische typen zijn beschreven in § 2.1.5.

Tabel geeft een korte omschrijving van de locaties die in het veld zijn bezocht. De locaties van de veldlocaties zijn weergegeven op de kaartjes van de Fysisch-Geografische typen per beekloop.

Tabel 3-1 Korte omschrijving veldwaarnemingen. De locaties zijn aangegeven in Figuur 3-1 t/m Figuur 3-6.

\begin{tabular}{|c|c|}
\hline Code & Omschrijving \\
\hline GR1 & Ingerichte oever Graafse Raam \\
\hline GR2 & Boring 2 \\
\hline GR4 & Monster m1 \\
\hline GR4b & Boring 1 bij GR4 boven talud 3m van oever \\
\hline HR1 & Ingerichte bovenloop Hooge Raam \\
\hline HR2 & Ingerichte bovenloop Hooge Raam \\
\hline HR3 & Drainagesloot in brongebied Graspeel \\
\hline HR4 & Boring 4 Oever Hooge Raam, opgestuwd \\
\hline HB2 & Benedenloop Halsche beek \\
\hline LR1 & Lage Raam bij Kwekerijweg \\
\hline LR2 & Lage Raam bij instroom St. Anthonisloop \\
\hline LR3 & Boring 5 Afgegraven zone tussen Lage Raam en Achterdijk \\
\hline BG1 & Boring 6 Oever Biestgraaf \\
\hline BG2 & Biestgraaf \\
\hline
\end{tabular}




\subsection{Graafsche Raam}

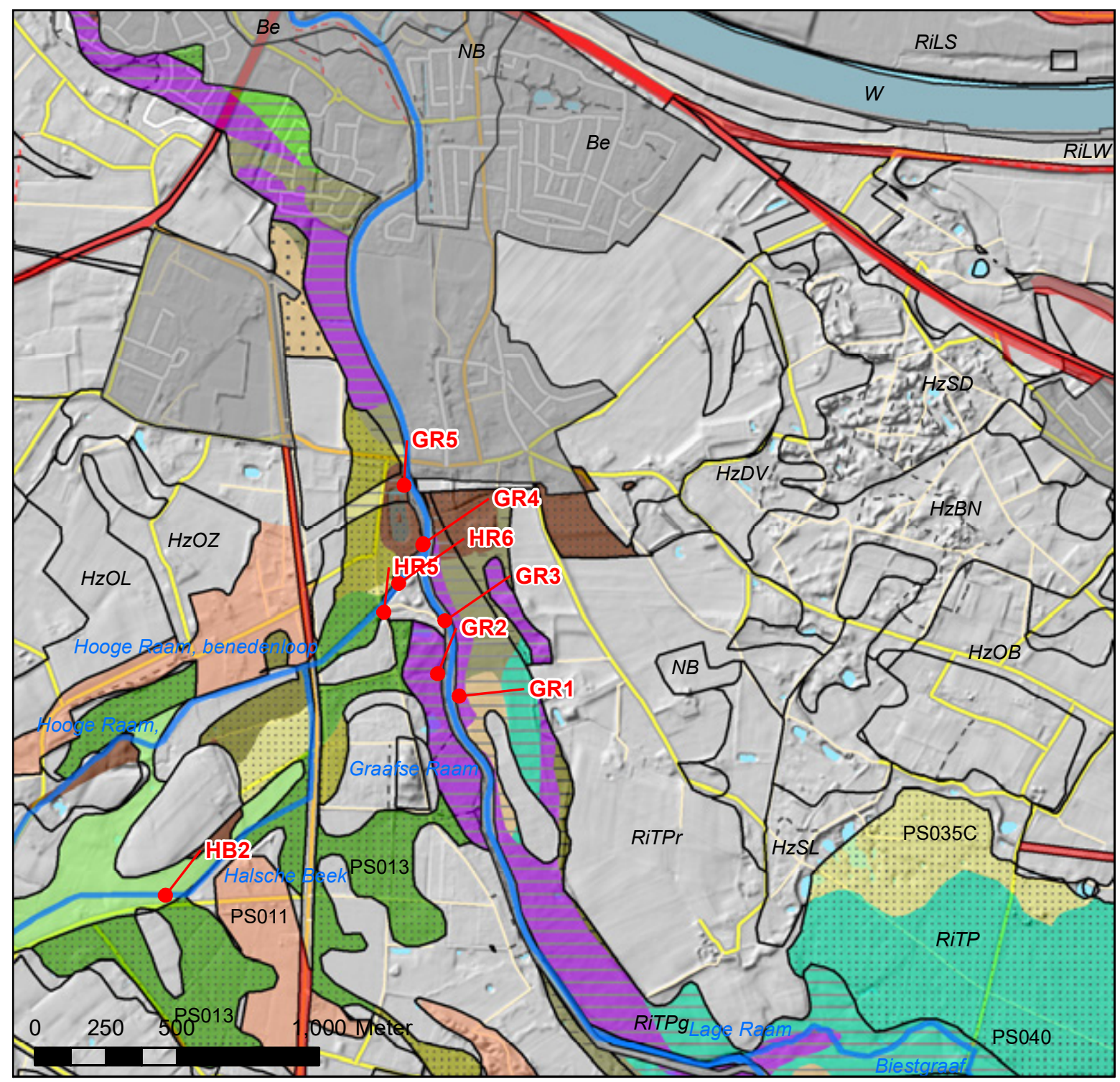

\section{Legenda}

- Veldwaarnemingen

Fysisch Geografische Series

\section{HzBN Natte en verdroogde beekdalen}

PS011 Atmotrofe vochtige zandgronden

PS013 Lithotrofe zandgrond gevoed door zwakke kwel

\section{HzOL Lage eerdgronden binnen de beekdalen}

PS113 Humeuze zandgronden met kwel (lage enkeerden)

\section{RiTP Pleistocene rivierterrassen}

.... PS012 Minerotrofe zandgronden met lateraal

:.:. toestromend zacht grondwater

:.:. PS013 Lithotrofe zandgrond gevoed door zwakke kwel

:. . PS034C Grofzandige rivierzandgronden (kalkarm)

:.:.: PS035C Fijnzandige rivierzandgronden (kalkarm)

_ - PS036C (Rivier)zandgronden met een kleidek (Kalkarm)

.... PS040 Matig basenarme Oude rivierkleigronden

..... PS110 Oud bouwland met een bovengrond van klei of zavel
PS113 Humeuze zandgronden met kwel (lage enkeerden)

\section{RiTPg Pleistocene rivierterrassen; Geulen}

_ PS013 Lithotrofe zandgrond gevoed door zwakke kwel PS027 Eutrofe, basenrijke bos- en broekveengronden;

RiTPg, PS027 Eutrofe, basenrijke bos- en broekveengronden

- PS034C Grofzandige rivierzandgronden (kalkarm)

- PS035C Fijnzandige rivierzandgronden (kalkarm)

PS036C (Rivier)zandgronden met een kleidek (Kalkarm)

PS040 Matig basenarme Oude rivierkleigronden

PS110 Oud bouwland met een bovengrond van klei of zavel

PS111 Hoge zandgronden met een zwart bouwlanddek

PS113 Humeuze zandgronden met kwel (lage enkeerden)

\section{Overig}

Water

Figuur 3-1 Fysisch-Geografische typen langs de Graafsche Raam. Cursief zijn de FG-series aangegeven. 


\subsubsection{Systeemkenmerken Graafsche Raam}

\begin{tabular}{|c|c|}
\hline Kenmerk & Informatie/opmerking \\
\hline Geomorfologie & $\begin{array}{l}\text { Gegraven/vergraven waterloop in een opgevulde restgeul van een vlechtend } \\
\text { riviersysteem in een pleistoceen rivierterras (Niersdalrijn \& Maas). Helling van het } \\
\text { rivierterras (oriëntatie: zzo-nnw) ca. } 0,30 \mathrm{~m} / \mathrm{km} \text {. }\end{array}$ \\
\hline Landschapsecologische positie & Eutrofe, basenrijke bos- en broekveengronden (PS027) \\
\hline Hydrologie/brongebied & $\begin{array}{l}\text { Waterloop voert neerslagoverschot van het rivierterras en kwelwater vanuit de } \\
\text { Peelhorst af. } \\
\text { Tot } 1942 \text { inundatie door de Maas als onderdeel van de Beersche overlaat. }\end{array}$ \\
\hline Bodemkundige setting & $\begin{array}{l}\text { Restgeul in zandig rivierterras (Form. Kreftenheye) gevuld met veen (Form. van } \\
\text { Nieuwkoop) en bedekt met holocene rivierklei van de Maas (Form. van Echteld) }\end{array}$ \\
\hline Dalverhang & $\begin{array}{l}\text { Gering, } 0,20 \mathrm{~m} / \mathrm{km} \text {. Het dalverhang is kleiner dan de helling van het terras doordat de } \\
\text { geul is opgevuld met veen. }\end{array}$ \\
\hline Geulpatroon & Lateraal stabiel; geen processen die samenhangen met actief meanderen. \\
\hline Gem. geulbreedte in evenwicht & $13,4 \mathrm{~m}$ \\
\hline Gem. geuldiepte in evenwicht & $1,3 \mathrm{~m}$ \\
\hline Sediment en banken & Stroomribbels, bankvorming onderdrukt \\
\hline
\end{tabular}
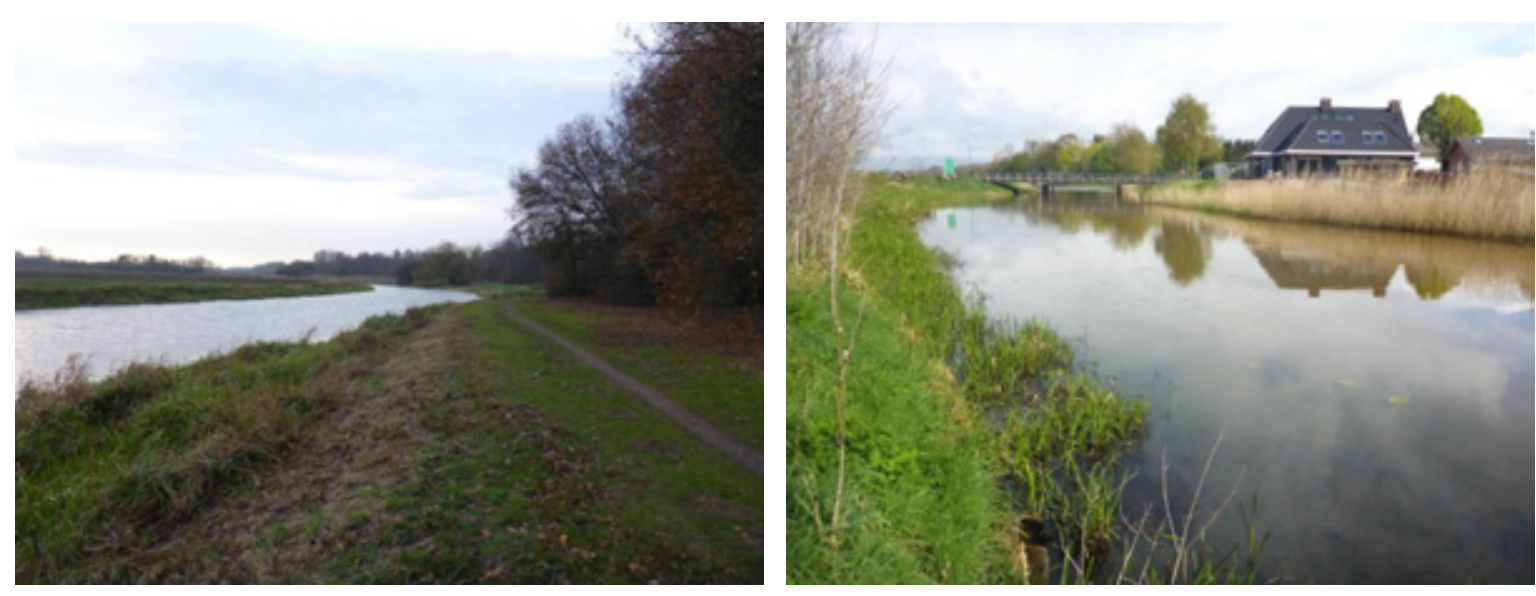

\subsubsection{Veldwaarnemingen}

\begin{tabular}{ll} 
Kenmerk & Informatie/opmerking \\
Substraat in oever en bedding & $\begin{array}{l}\text { Op de locatie van boring GR4 bestaat de bedding van de geul uit ca. } 50 \mathrm{~cm} \text { humeus } \\
\text { zand op kleiig veen; de zuidwestoever van de Graafsche Raam snijdt ter hoogte van de } \\
\text { instroom van de Hooge Raam (tussen GR4 en GR5) zandige terrasafzettingen aan. }\end{array}$ \\
\hline Beekpatronen en dimensies & $\begin{array}{l}\text { Graafsche Raam volgt het patroon van een natuurlijke restgeul in het terras; de } \\
\text { geschatte (AHN) bovenbreedte van de is geul 33-35m, bodembreedte geul ca. } 25 \text { m; } \\
\text { geuldiepte }>1,8 \mathrm{~m} .\end{array}$ \\
\hline Morfologische processen & $\begin{array}{l}\text { Geen banken in de bedding of oeverzone die samenhangen met transport van } \\
\text { sediment; over grote lengte ontwikkeling van verlandingsvegetaties (liesgras en riet) } \\
\text { in de oeverzone met een maximumbreedte van ca. 10m. }\end{array}$ \\
\hline Landschapsecologische setting & Kwelverschijnselen in de verlandingszone \\
(drainage/kwel) &
\end{tabular}




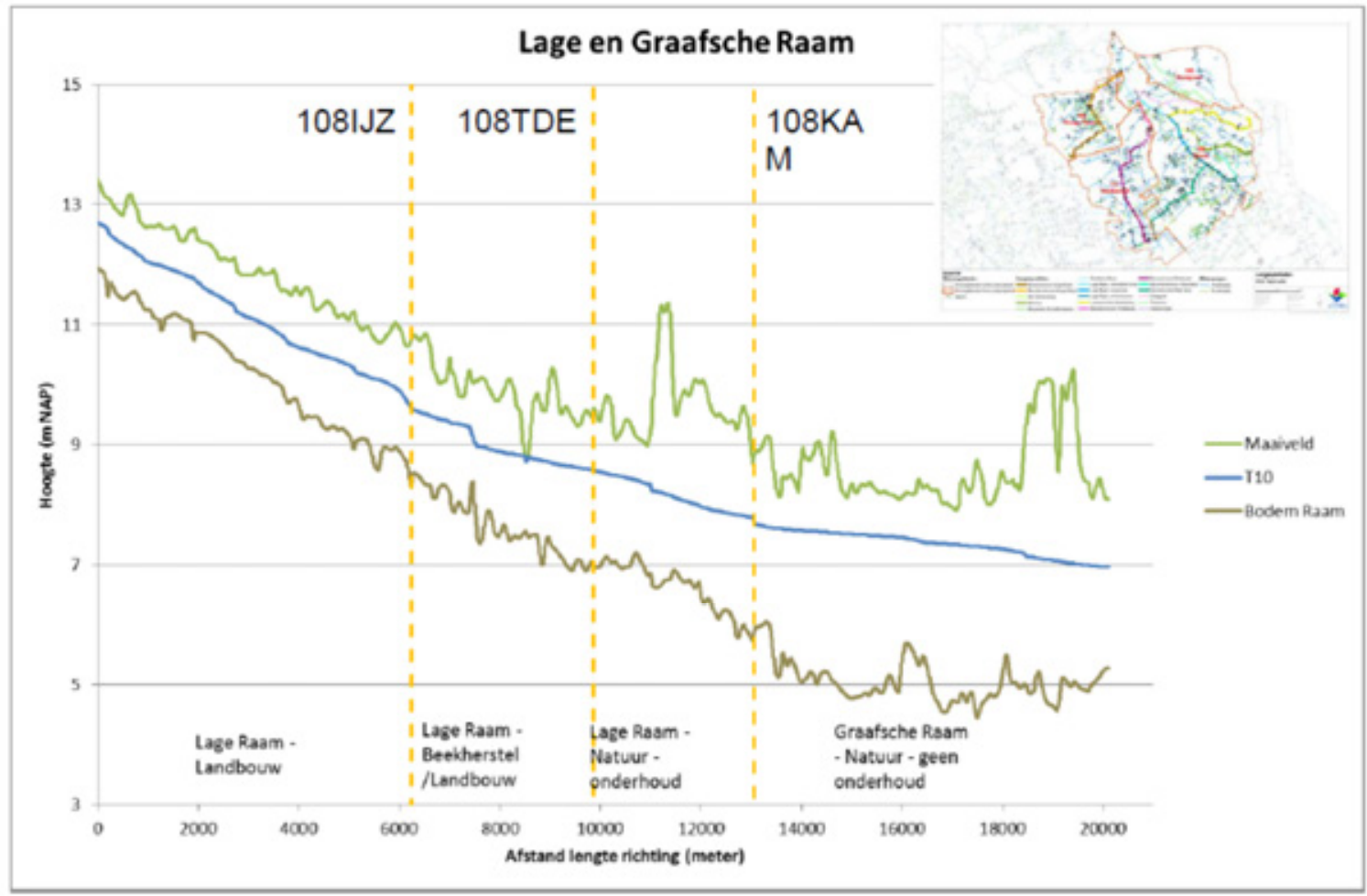




\subsection{Hooge Raam}

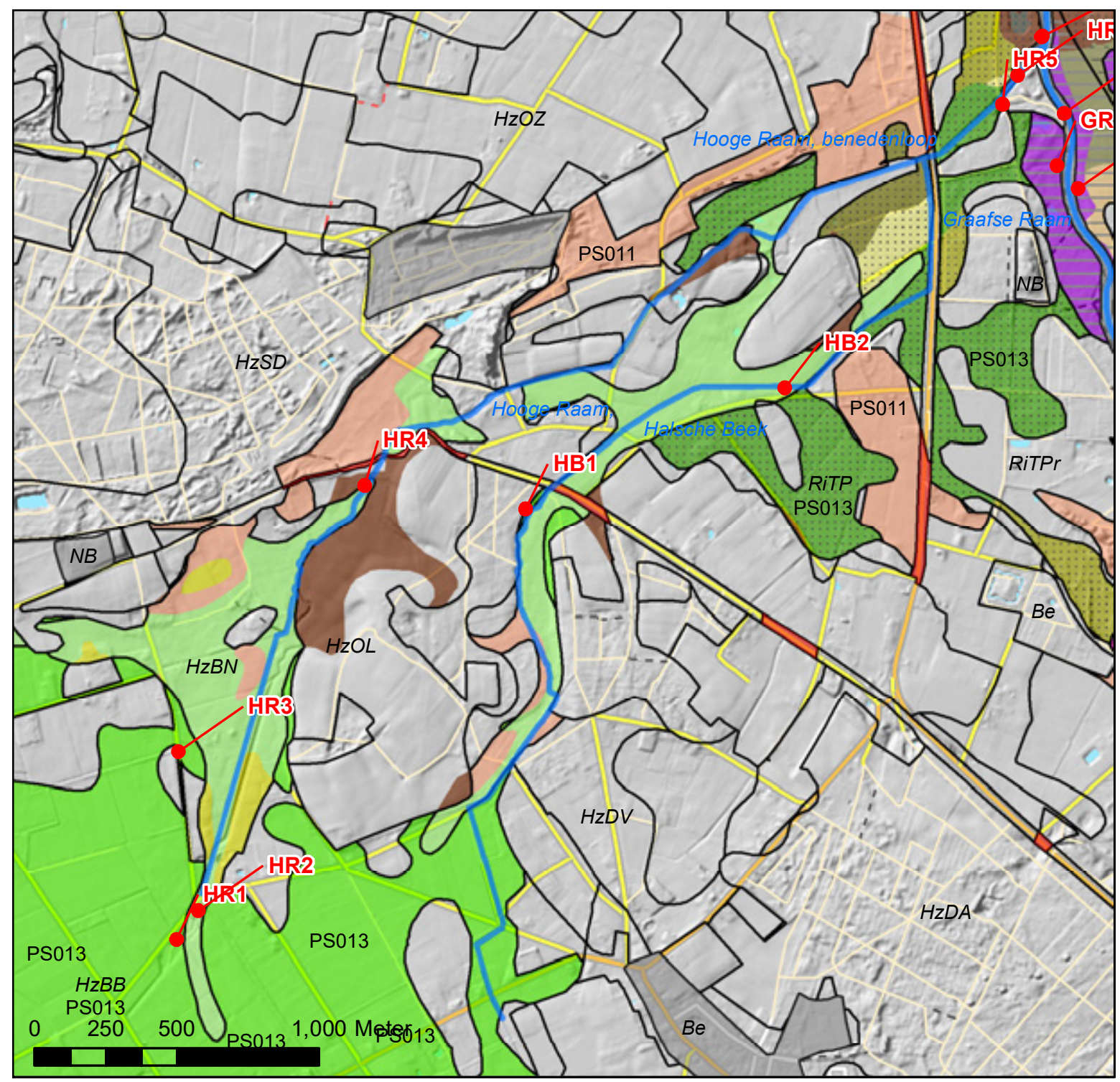

\section{Legenda}

- Veldwaarnemingen

$\square$ Fysisch Geografische Series

HzBB Brongebieden binnen Beekdalen

PS013 Lithotrofe zandgrond gevoed door zwakke kwel

\section{HzBN Natte en verdroogde beekdalen}

PS011 Atmotrofe vochtige zandgronden

PS012 Minerotrofe zandgronden met lateraal toestromend zacht grondwater

PS013 Lithotrofe zandgrond gevoed door zwakke kwel

\section{HzOL Lage eerdgronden binnen de beekdalen}

PS113 Humeuze zandgronden met kwel (lage enkeerden)

\section{RiTP Pleistocene rivierterrassen}

.... PS012 Minerotrofe zandgronden met lateraal

$\therefore$ toestromend zacht grondwater

..:. PS013 Lithotrofe zandgrond gevoed door zwakke kwe -. PS034C Grofzandige rivierzandgronden (kalkarm)
...: PS035C Fijnzandige rivierzandgronden (kalkarm)

- - PS036C (Rivier)zandgronden met een kleidek (Kalkarm)

..... PS110 Oud bouwland met een bovengrond van klei of zavel

PS113 Humeuze zandgronden met kwel (lage enkeerden)

\section{RiTPg Pleistocene rivierterrassen; Geulen}

PS026 Zoet en zwak brak verlandingsveen PS027 Eutrofe, basenrijke bos- en broekveengronden;

RiTPg, PS027 Eutrofe, basenrijke bos- en broekveengronden

_ PS034C Grofzandige rivierzandgronden (kalkarm)

— PS035C Fijnzandige rivierzandgronden (kalkarm)

PS036C (Rivier)zandgronden met een kleidek (Kalkarm) PS113 Humeuze zandgronden met kwel (lage enkeerden)

\section{Overig}

Water

Figuur 3-2 Fysisch-Geografische typen langs de Hooge Raam en Halsche beek. Cursief zijn de FGseries aangegeven. 


\subsubsection{Systeemkenmerken Hooge Raam}

\begin{tabular}{|c|c|}
\hline Kenmerk & Informatie/opmerking \\
\hline Geomorfologie & $\begin{array}{l}\text { Gegraven/vergraven waterloop in een zuidwest-noordoost georiënteerd Pleistoceen } \\
\text { erosiedal op de oostflank van de Peelhorst. }\end{array}$ \\
\hline Hydrologie/brongebied & $\begin{array}{l}\text { Waterloop draineert de Graspeel, een kwelgebied op een tussenterras van Peelhorst. } \\
\text { Door tektoniek langs breuken in de ondergrond ligt de top van de Formatie van Breda } \\
\text { (kleipakket) ter plaatse van de Hooge Raam relatief hoog in het geologisch profiel. }\end{array}$ \\
\hline Bodemkundige setting & $\begin{array}{l}\text { Het erosiedal is ingesneden in grofzandig en grindrijk terrasmateriaal (Form. van } \\
\text { Beegden) en opgevuld met matig fijnzandig zand uit de Form. Boxtel en/of holocene } \\
\text { beekafzettingen. Op de hoge ruggen aan weerszijden van het dal ligt het grove zand } \\
\text { aan maaiveld (HR4; Figuur ). Op de plekken waar de Hooge Raam in de daklflank dit } \\
\text { grove materiaal aansnijdt, komt in de bedding grof zand en grind voor. }\end{array}$ \\
\hline Geulvullende afvoer & $1,801-1,604 \mathrm{~m}^{3} / \mathrm{sec} .(\mathrm{T} 1)$ \\
\hline Geulpatroon & Meanderend met plaatsvaste kronkelwaardbanken (scrolls). \\
\hline Gem. geulbreedte in evenwicht & $6,7 \mathrm{~m}$ \\
\hline Gem. geuldiepte in evenwicht & $0,4 \mathrm{~m}$ \\
\hline Sediment en banken & Stroomribbels en lage duinen, plaatsvaste banken in de binnenbocht. \\
\hline
\end{tabular}

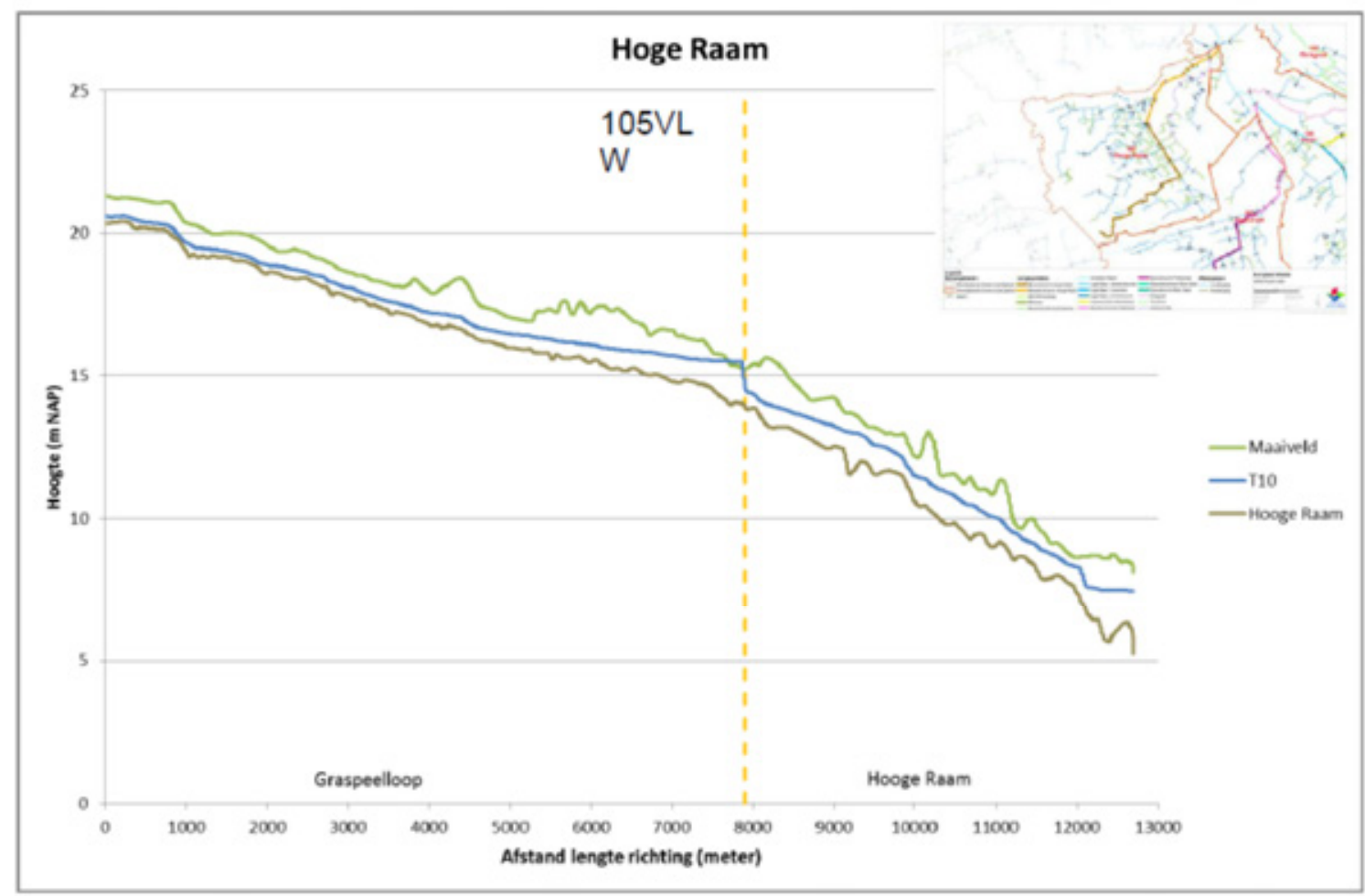




\subsubsection{Veldwaarnemingen}

\begin{tabular}{ll} 
Kenmerk & Informatie/opmerking \\
Substraat in oever en bedding & $\begin{array}{l}\text { Matig fijn zand in oever en bedding, lutum en ijzerhoudende houdende bovengrond } \\
\text { verhogen lokaal de oeverstabiliteit (locatie boring HR4). }\end{array}$ \\
\hline Beekpatronen en dimensies & $\begin{array}{l}\text { Rechte tot licht slingerende loop met steile oevers; bovenbreedte (gemeten) 6,70 m; } \\
\text { bodembreedte } 6,70 \mathrm{~m} ; \text { geuldiepte ca. } 1,25 \mathrm{~m} .\end{array}$ \\
\hline Morfologische processen & $\begin{array}{l}\text { Lokaal geringe oevererosie (in rechte delen van de loop), geen bankvorming in de } \\
\text { bedding of sedimentatie in de oeverzone wargenomen; stuwen dempen morfologische } \\
\text { processen. }\end{array}$ \\
\hline $\begin{array}{l}\text { Landschapsecologische setting } \\
\text { (drainage/kwel) }\end{array}$ & Geen kwelverschijnselen in de beek of aan maaiveld beekdal.
\end{tabular}

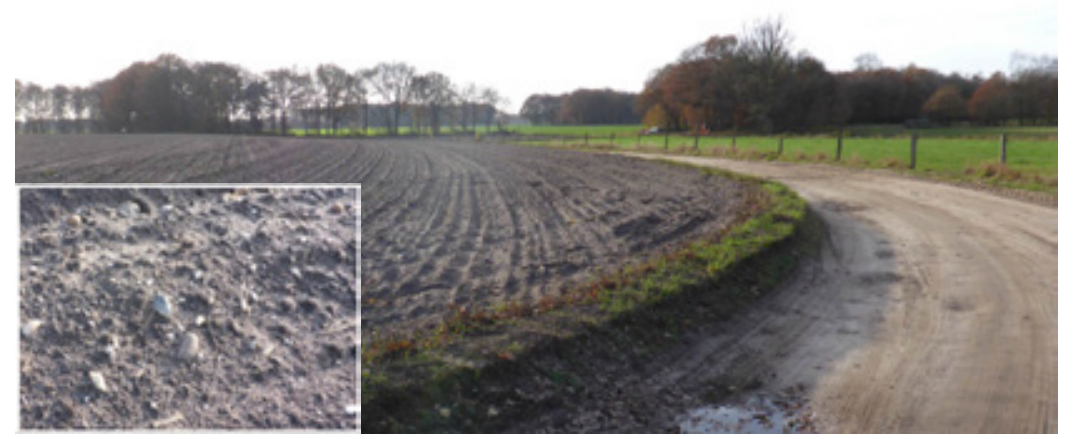

Figuur 3-3 Hoge rug met bouwland langs de het dal van de Hooge Raam. De bouwvoor van de akker bestaat uit grof zand en grind (zie inzet). 


\subsection{Halsche Beek}

\subsubsection{Systeemkenmerken Halsche Beek}

Zie voor de kaart van de Fysisch-Geografische typen van de Biestgraaf § 3.4 Lage Raam.

\begin{tabular}{|c|c|}
\hline Kenmerk & Informatie/opmerking \\
\hline Geomorfologie & $\begin{array}{l}\text { Gegraven/vergraven waterloop in een zuidwest-noordoost georiënteerd Pleistoceen } \\
\text { erosiedal op de oostflank van de Peelhorst. }\end{array}$ \\
\hline $\begin{array}{l}\text { Primaire Landschapsecologische } \\
\text { positie }\end{array}$ & $\begin{array}{l}\text { Lithotrofe zandgrond gevoed door zwakke kwel (PSO13) binnen natte en verdroogde } \\
\text { beekdalen (HzBN). }\end{array}$ \\
\hline Hydrologie/brongebied & $\begin{array}{l}\text { Waterloop draineert de oostzijde van de Graspeel, een kwelgebied op een tussenterras } \\
\text { van Peelhorst. Door tektoniek langs breuken in de ondergrond ligt de top van de } \\
\text { Formatie van Breda (kleipakket) ter plaatse van de Halsche Beek relatief hoog in het } \\
\text { geologisch profiel. }\end{array}$ \\
\hline Bodemkundige setting & $\begin{array}{l}\text { Het erosiedal is bovenstrooms ingesneden in grofzandig en grindrijk terrasmateriaal } \\
\text { (Form. van Beegden). Grof zand en grind komen voor in de dalflanken en in de } \\
\text { dalbodem. Benedenstrooms is het dal opgevuld met matig fijn zand (Form. Boxtel } \\
\text { en/of holocene beekafzettingen). }\end{array}$ \\
\hline Dalverhang & $\begin{array}{l}\text { In het steilste traject is het dalverhang } 3,9 \mathrm{~m} / \mathrm{km} \text {, stroomafwaarts neemt dit af naar } \\
1,1 \mathrm{~m} / \mathrm{km} \text {. }\end{array}$ \\
\hline Oeverstabiliteit & $\begin{array}{l}\text { In de trajecten met matig fijn zand is de oeverstabiliteit laag; de grindrijke trajecten } \\
\text { hebben een hogere stabiliteit i.v.m. de afname van transportcapaciteit. }\end{array}$ \\
\hline Geulvullende afvoer & $0,197 \mathrm{~m}^{3} / \mathrm{sec} .(\mathrm{T} 1)$ \\
\hline Geulpatroon & Meanderend met plaatsvaste kronkelwaardbanken (scrolls). \\
\hline Gem. geulbreedte in evenwicht & $2,2 \mathrm{~m}$ \\
\hline Gem. geuldiepte in evenwicht & $0,2 \mathrm{~m}$ \\
\hline Sediment en banken & $\begin{array}{l}\text { Stroomribbels en lage duinen, plaatsvaste banken in de binnenbocht bij een D50 van } \\
218 \mu \mathrm{m} \text {. }\end{array}$ \\
\hline
\end{tabular}

\subsubsection{Veldwaarnemingen}

Kenmerk
Substraat in oever en bedding

Beekpatronen en dimensies

Morfologische processen

Landschapsecologische setting

(drainage/kwel)

\section{Informatie/opmerking}

Boven- en benedenstroomse deeltrajecten met matig fijn zand (resp. HR2, HB2); daartussen een traject met grof zand en grind in oever en bedding (HB1); in dit traject is in het aangrenzende bosperceel op $60 \mathrm{~cm}$ diepte een $50 \mathrm{~cm}$ dikke laag zware klei aangetroffen.

Voornamelijk rechte loop met lokaal lichte neiging tot meanderen binnen de bedding; in het grofzandige traject licht slingerend patroon, samenvallend met de grens van het bos. Loop ligt niet in het laagste deel van het erosiedal. Bovenbreedte (gemeten) 3,404,70 m; bodembreedte 1,10-2,20 m; geuldiepte 1,50-1,60 m.

In de beek geen actieve meanderprocessen (erosie -sedimentatie) waargenomen. Droogval in het bovenstroomse grofzandige traject; kwelverschijnselen in de drooggevallen beekbodem (Figuur). 


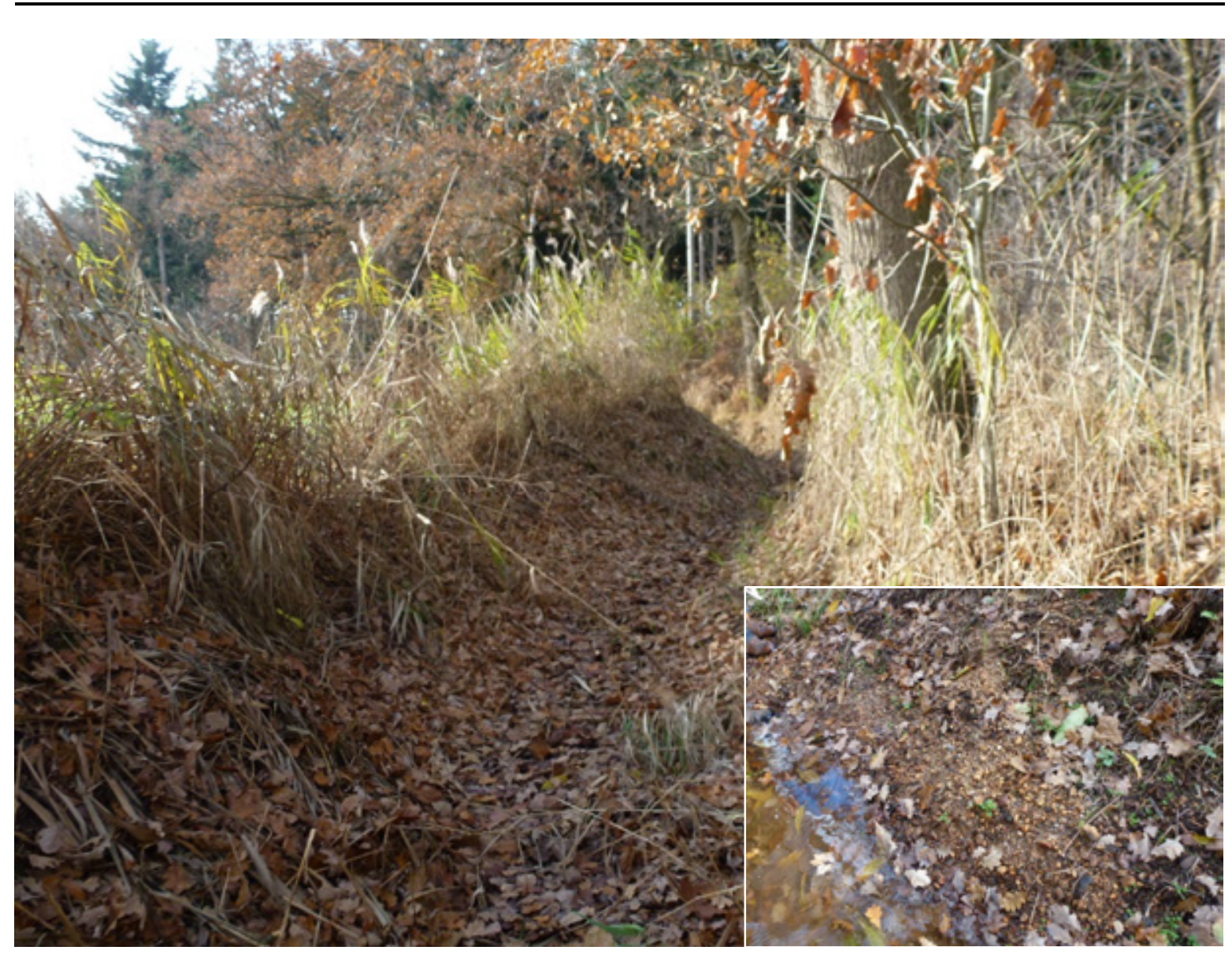

Figuur 3-4 Drooggevallen bedding in de middenloop van de Halsche Beek. Het beddingmateriaal bestaat uit grof zand en grind (zie inzet).

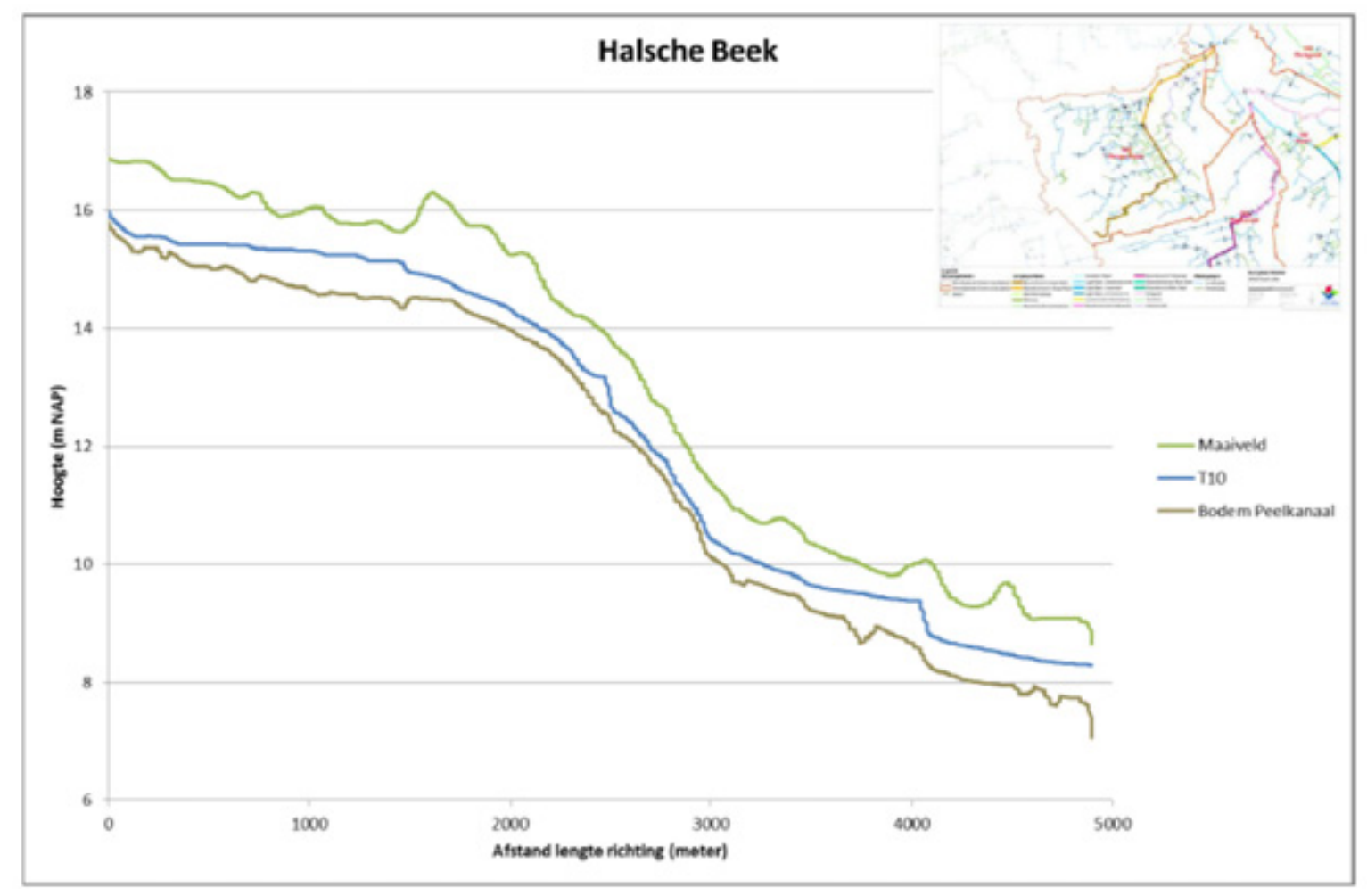




\subsection{Lage Raam}

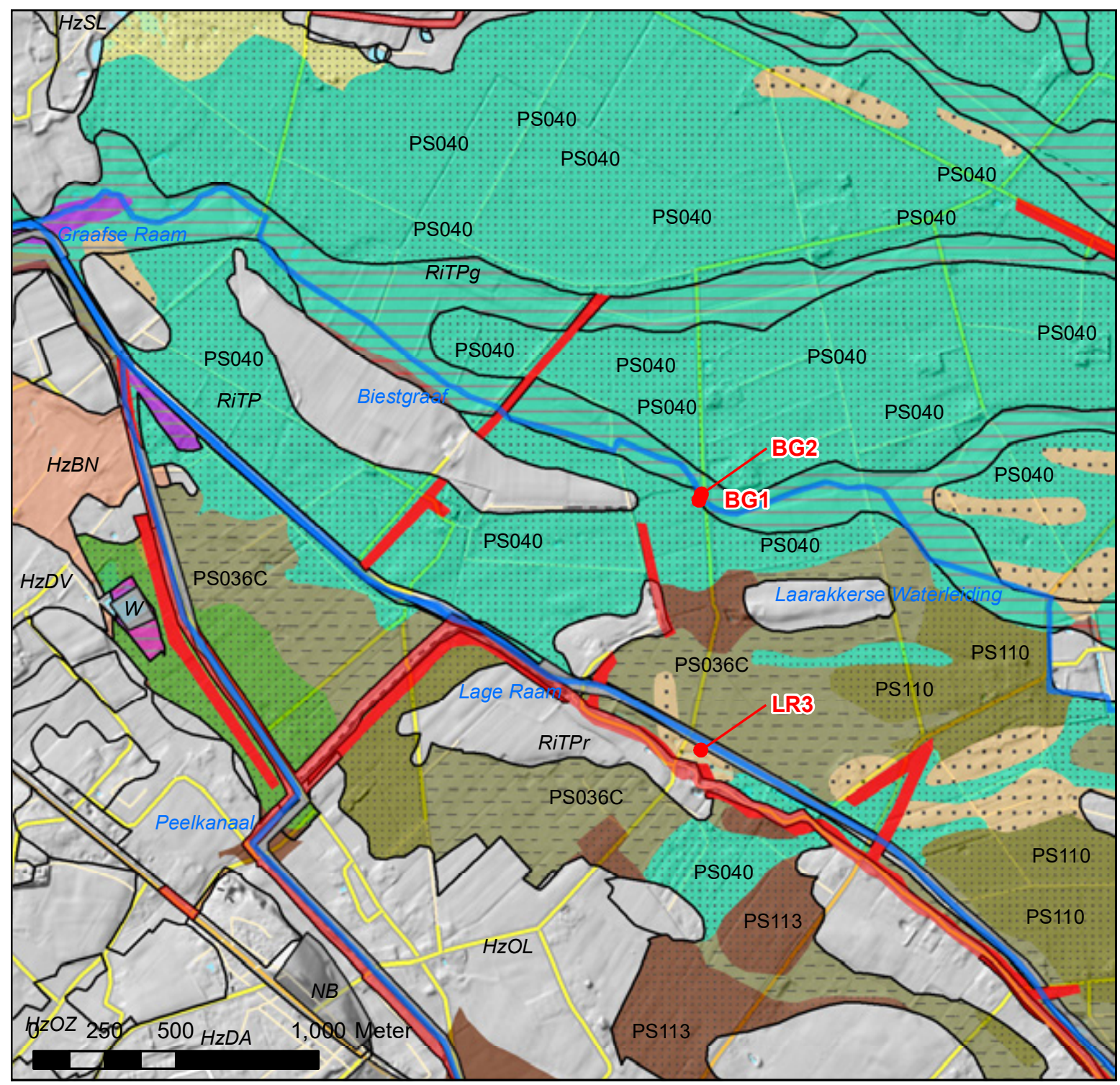

\section{Legenda}

- Veldwaarnemingen

Fysisch Geografische Series

HzBN Natte en verdroogde beekdalen

PS011 Atmotrofe vochtige zandgronden

HzOL Lage eerdgronden binnen de beekdalen

PS113 Humeuze zandgronden met kwel (lage enkeerden)

\section{RiTP Pleistocene rivierterrassen}

.... PS012 Minerotrofe zandgronden met lateraal .... toestromend zacht grondwater

2... PS013 Lithotrofe zandgrond gevoed door zwakke kwel

:... PS034C Grofzandige rivierzandgronden (kalkarm)

..:. PS035C Fijnzandige rivierzandgronden (kalkarm)

- - PS036C (Rivier)zandgronden met een kleidek (Kalkarm)

2... PS040 Matig basenarme Oude rivierkleigronden

..... PS110 Oud bouwland met een bovengrond van klei of zavel
PS113 Humeuze zandgronden met kwel (lage enkeerden)

\section{RiTPg Pleistocene rivierterrassen; Geulen}

PS026 Zoet en zwak brak verlandingsveen

PS027 Eutrofe, basenrijke bos- en broekveengronden;

RiTPg, PS027 Eutrofe, basenrijke bos- en broekveengronden

- PS034C Grofzandige rivierzandgronden (kalkarm)

PS036C (Rivier)zandgronden met een kleidek (Kalkarm)

_ PS040 Matig basenarme Oude rivierkleigronden

PS111 Hoge zandgronden met een zwart bouwlanddek

PS112 Hoge zandgronden met een bruin bouwlanddek

PS113 Humeuze zandgronden met kwel (lage enkeerden)

\section{Overig}

Water

Dijk

Figuur 3-5 Fysisch-Geografische typen langs de Westelijk deel van de Lage Raam en Biestgraaf/Laarakkerse Waterleiding. Cursief zijn de FG-series aangegeven. 


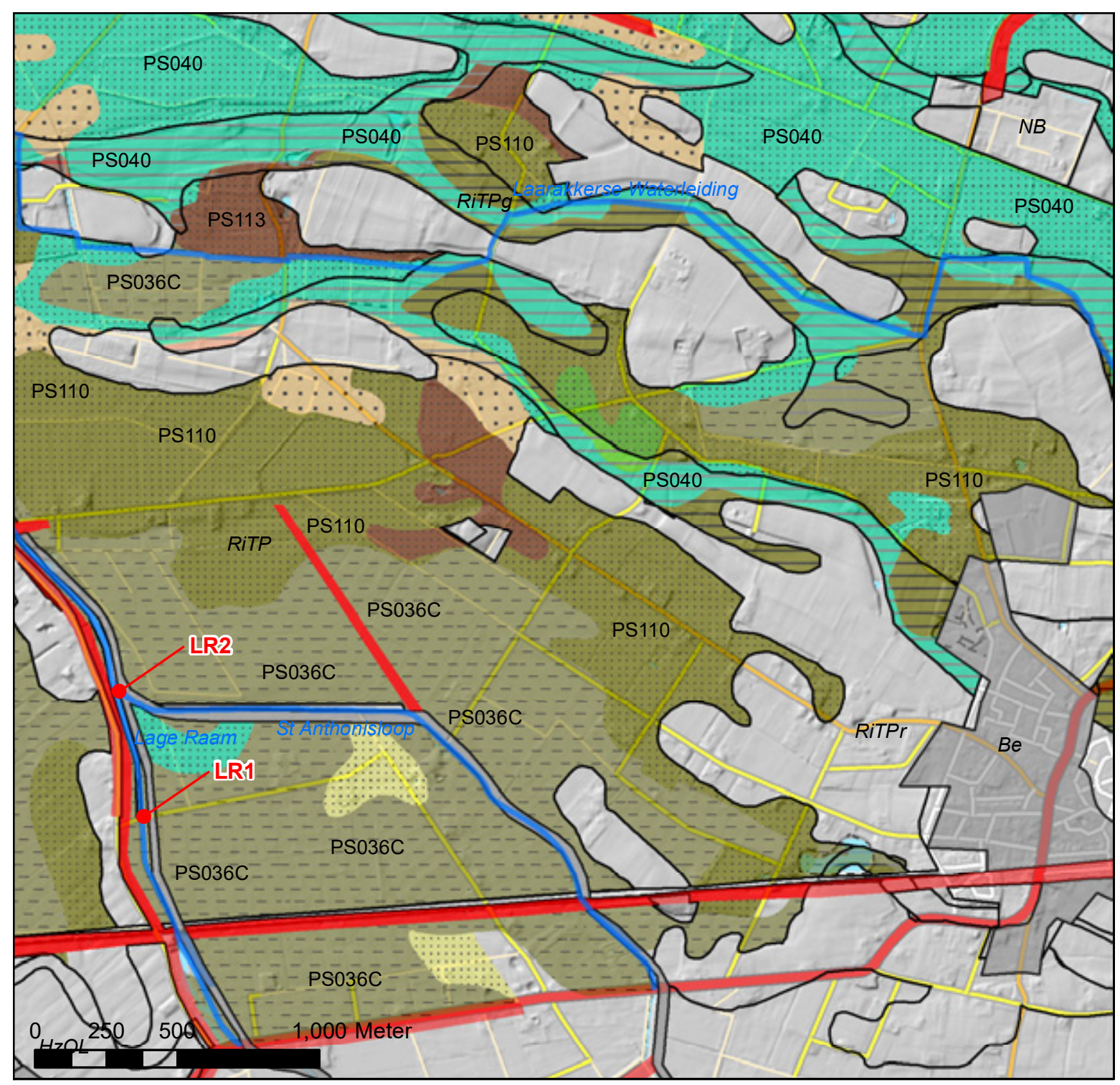

\section{Legenda}

- Veldwaarnemingen

Fysisch Geografische Series

\section{RiTP Pleistocene rivierterrassen}

2.: PS013 Lithotrofe zandgrond gevoed door zwakke kwel ...PS034C Grofzandige rivierzandgronden (kalkarm)

:..: PS035C Fijnzandige rivierzandgronden (kalkarm)

___ PS036C (Rivier)zandgronden met een kleidek (Kalkarm)

:.:.: PS040 Matig basenarme Oude rivierkleigronden

PS110 Oud bouwland met een bovengrond van klei of zavel

PS113 Humeuze zandgronden met kwel (lage enkeerden)

\section{RiTPg Pleistocene rivierterrassen; Geulen}

- RiTPg, PS011 Atmotrofe vochtige zandgronden

_ PS013 Lithotrofe zandgrond gevoed door zwakke kwel

— PS034C Grofzandige rivierzandgronden (kalkarm)

PS036C (Rivier)zandgronden met een kleidek (Kalkarm)

- PS040 Matig basenarme Oude rivierkleigronden

PS110 Oud bouwland met een bovengrond van klei of zavel

PS112 Hoge zandgronden met een bruin bouwlanddek

PS113 Humeuze zandgronden met kwel (lage enkeerden)

\section{Overig}

Water

Dijk

Figuur 3-6 Fysisch-Geografische typen langs de Oostelijk deel van de Lage Raam en Biestgraaf/Laarakkerse Waterleiding. Cursief zijn de FG-series aangegeven. 


\subsubsection{Systeemkenmerken Lage Raam}

\begin{tabular}{|c|c|}
\hline Kenmerk & Informatie/opmerking \\
\hline Geomorfologie & $\begin{array}{l}\text { Gegraven/vergraven waterloop in pleistoceen rivierterras (Niersdalrijn \& Maas). Helling } \\
\text { van het rivierterras (oriëntatie: zzo-nnw) ca. 0,30 m/km. In tegenstelling tot de } \\
\text { Biestgraaf ligt de Lage Raam niet in een stelsel van terrasrestgeulen, maar in de } \\
\text { terrasvlakte. De natuurlijke laagten ontbreken in dit deel van het tegen de flank van de } \\
\text { Peelhorst gelegen rivierterras. }\end{array}$ \\
\hline Hydrologie/brongebied & $\begin{array}{l}\text { Waterloop ontspringt in het Wanroijse Broek en voert met name neerslagoverschot van } \\
\text { het rivierterras en kwelwater vanuit de Peelhorst af. Tot } 1942 \text { inundeerde de Maas de } \\
\text { benedenloop van de Lage Raam als onderdeel van de Beersche overlaat. In de } \\
\text { benedenloop mondt het Peelkanaal uit in de Lage Raam. }\end{array}$ \\
\hline Dalverhang & Gering, 0,28 m/km; vrijwel gelijk aan de helling van het terras. \\
\hline Oeverstabiliteit & Laag-matig, matig grof tot matig fijn zand. Kleidek heeft een stabiliserende werking. \\
\hline Geulvullende afvoer & Benedenloop: 4,5 m³/sec. (T1); middenloop: 2,308 m3/sec. (T1) \\
\hline Geulpatroon & Lateraal stabiel; geen processen die samenhangen met actief meanderen. \\
\hline Gem. geulbreedte in evenwicht & Benedenloop: $8,5 \mathrm{~m}$; middenloop: $6,1 \mathrm{~m}$ \\
\hline Gem. geuldiepte in evenwicht & Benedenloop: 0,91 m; middenloop: 0,73 m \\
\hline
\end{tabular}

\subsubsection{Veldwaarnemingen}

\begin{tabular}{ll}
$\begin{array}{l}\text { Kenmerk } \\
\text { Substraat in oever en bedding }\end{array}$ & $\begin{array}{l}\text { Informatie/opmerking } \\
\text { fijn zand. }\end{array}$ \\
\hline Beekpatronen en dimensies & $\begin{array}{l}\text { Lage Raam heeft een rechte loop en ligt ingegraven in terrasvlakte. Bovenbreedte geul } \\
\text { ca.16,6 m; geuldiepte }>1,2 \mathrm{~m} .\end{array}$ \\
\hline Morfologische processen & $\begin{array}{l}\text { Geen banken in de bedding of oeverzone die samenhangen met transport van } \\
\text { sediment; over grote lengte ontwikkeling van verlandingsvegetaties (liesgras en riet) } \\
\text { in de oeverzone. Oevertalud lokaal verlaagd t.b.v. natuurontwikkeling. }\end{array}$ \\
\hline $\begin{array}{l}\text { Landschapsecologische setting } \\
\text { (drainage/kwel) }\end{array}$ & Kwelverschijnselen in de verlandingszone van ingerichte oever. \\
\hline
\end{tabular}




\subsection{Biestgraaf}

\subsubsection{Systeemkenmerken Biestgraaf}

Zie voor de kaart van de Fysisch-Geografische typen van de Biestgraaf § 3.4 Lage Raam.

\begin{tabular}{ll} 
Kenmerk & Informatie/opmerking \\
Geomorfologie & $\begin{array}{l}\text { Gegraven/vergraven waterloop in opgevulde restgeulen van een vlechtend } \\
\text { riviersysteem in pleistoceen rivierterras (Niersdalrijn \& Maas). Helling van het } \\
\text { rivierterras (oriëntatie: zzo-nnw) ca. 0,30 m/km. Waterloop verbindt min of meer } \\
\text { geïsoleerde restgeulen door doorgravingen van hogere terrasruggen. Morfologisch } \\
\text { patroon benedenloop mogelijk ontstaan onder invloed van de afvoer van Maaswater } \\
\text { via de Beersche Overlaat. }\end{array}$ \\
\hline Primaire Landschapsecologische & Matig basenarme Oude rivierkleigronden \\
\hline positie & Waterloop voert met name neerslagoverschot van het rivierterras en kwelwater vanuit \\
\hline Hydrologie/brongebied & $\begin{array}{l}\text { de Peelhorst af. } \\
\text { Tot } 1942 \text { inundatie door de Maas als onderdeel van de Beersche overlaat. }\end{array}$ \\
\hline Bodemkundige setting & $\begin{array}{l}\text { In met holocene rivierklei van de Maas (Form. van Echteld) opgevulde restgeulen in } \\
\text { zandig rivierterras (Form. Kreftenheye). Op locaties waar de Biestgraaf door } \\
\text { terrasruggen is gegraven, bestaat de ondergrond uit matig fijn rivierzand (Form. } \\
\text { Kreftenheye). }\end{array}$ \\
\hline Dalverhang & Gering, 0,32 $\mathrm{m} / \mathrm{km}$ \\
\hline Oeverstabiliteit & Hoog, door klei in de oevers en in de bedding. \\
\hline Geulvullende afvoer & $11,15 \mathrm{~m}^{3} / \mathrm{sec}$ (T1) \\
\hline Geulpatroon & Lateraal stabiel; geen processen die samenhangen met actief meanderen. \\
\hline Gem. geulbreedte in evenwicht & $4,3 \mathrm{~m}$ \\
\hline Gem. geuldiepte in evenwicht & $0,56 \mathrm{~m}$ \\
\hline Sediment en banken & Stroomribbels, bankvorming onderdrukt. \\
\hline
\end{tabular}

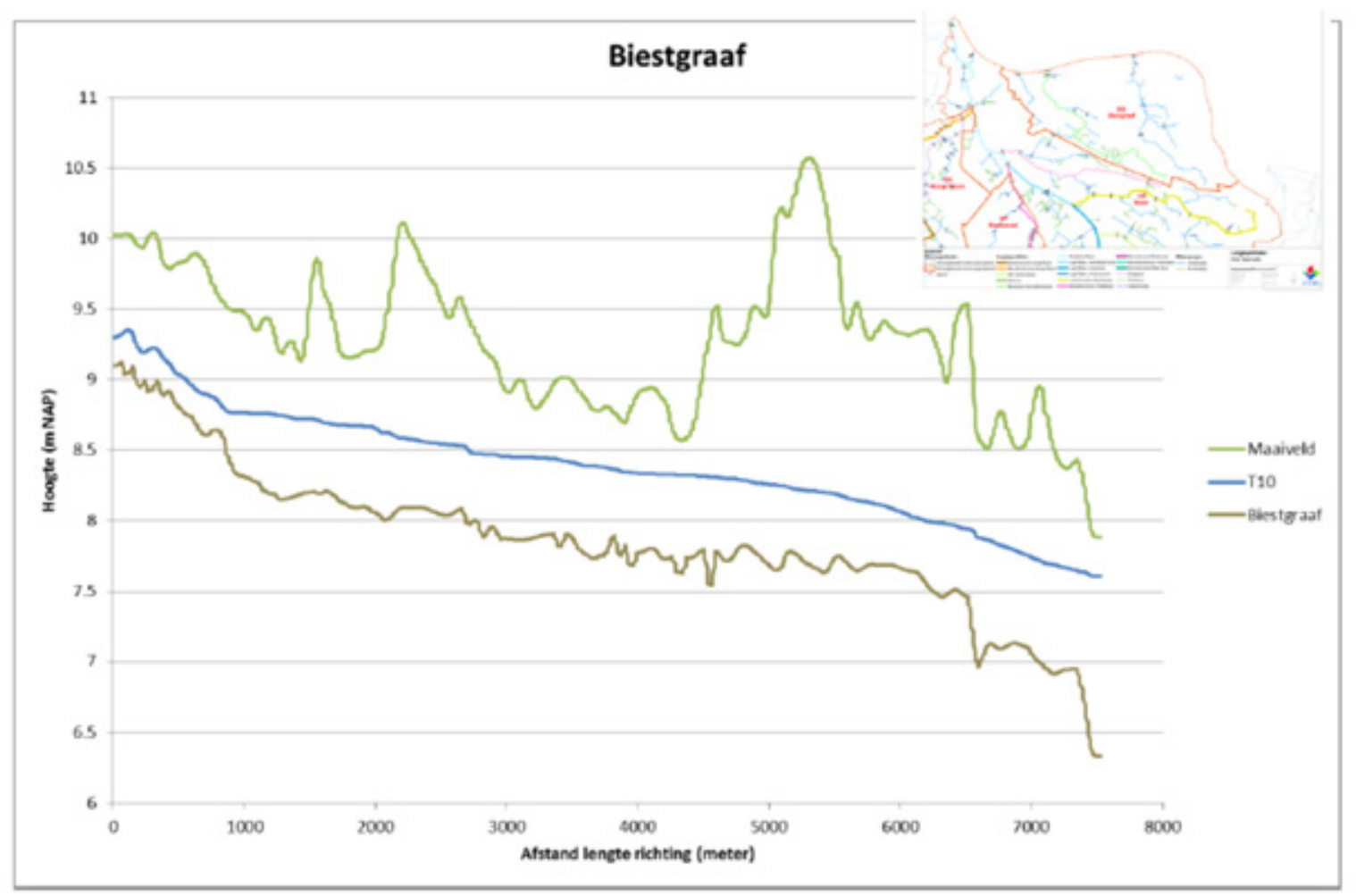




\subsubsection{Veldwaarnemingen}

\begin{tabular}{ll} 
Kenmerk & Informatie/opmerking \\
Substraat in oever en bedding & Op de locatie van de boring (BG1) bestaat het beddingmateriaal van de geul uit matig \\
& $\begin{array}{l}\text { grof zand. Het bodemprofiel op de oever (BG2) bestaat uit matig fijn zand met een } \\
\text { kleidek. }\end{array}$ \\
\hline Beekpatronen en dimensies & Loop van de Biestgraaf volgt globaal het reliëf van het landschap, maar doorsnijdt ook \\
& terrasruggen. Biestgraaf ligt niet altijd in het laagste deel van de restgeul. \\
& Bovenbreedte geul 6,70 m; bodembreedte 3,30 m; geuldiepte 1,2 m. \\
\hline Morfologische processen & Geen banken in de bedding of oeverzone die samenhangen met transport van \\
& sediment. \\
\hline $\begin{array}{l}\text { Landschapsecologische setting } \\
\text { (drainage/kwel) }\end{array}$ & Geen zichtbare kwelverschijnselen. \\
\hline
\end{tabular}




\section{Referentiebeeld en maatregelen voor beekherstel in de Raamvallei}

In dit hoofdstuk wordt een aantal BwN-maatregelen op een rij gezet die bijdragen aan de ontwikkeling van een beeksysteem dat past bij de geomorfologische én landschapsecologische karakteristieken van het gebied. De volgende twee vragen aan de orde:

- Welke referentiebeelden passen bij de karakteristieken van de Raamvallei?

- Welke maatregelen kunnen genomen worden om de waterlopen in de Raamvallei in de huidige situatie te bewegen in de richting van de referentiebeelden?

\subsection{Landschapsecologische referentiebeelden voor de Raamvallei}

De resultaten van de landschapsecologische (§ 2.1) en de geomorfologische (§ 2.2) analyse zijn samengevat in vier referentiebeelden voor de Raamvallei:

- Bovenstroomse kwelmoerassen en bronbeken

- Snelstromende terrasbeek met een zandbedding

- Kwelmoeras hellingvoet

- Moerasbeek in verlande restgeul

In Figuur 4-1 zijn de gebieden waarvoor de referentiebeelden van toepassing zijn, weergegeven. De referentiebeelden zijn niet een-op-een gekoppeld aan de in hoofdstuk 3 beschreven beektrajecten, maar aan de landschapsecologische positie van delen van het stroomgebied van de Raam.

De referentiebeelden schetsen een beekdalbreed natuurbeeld van de Raamvallei en vormen één samenhangend systeem. Om op termijn het referentiebeeld van een goed functionerende snelstromende terrasbeek te kunnen benaderen, is het noodzakelijk dat ook het brongebied van de beek op het terras daarop is ingericht. Beekdalbreed betekent in dit kader dat we naar de waterloop in de context van het omringende landschap hebben gekeken i.c.m. de natuurlijk vegetatietypen die zich in potentie in het dal kunnen ontwikkelen. Dus beekloop in samenhang met de omgeving.

Van elk referentiebeeld geven we ter inspiratie een fotobeeld van een min of meer vergelijkbare situatie elders in Nederland met vergelijkbare condities. Daarna beschrijven we in tabelvorm, aan de hand van literatuur en de resultaten uit de landschapsecologische en geomorfologische analyse, een aantal karakteristieken van het referentiesysteem.

Bij het opstellen van deze referentieprofielen zijn de volgende bronnen gebruikt:

- Doorstroommoerassen en moerasbeken; typebeschrijvingen en ontwikkeling maatlatten voor de biologische kwaliteitselementen (Verdonschot et al., 2016);

- Ecologische streefbeelden. Ecologische verbindingszones, beekherstel, natuurvriendelijke oevers en overige wateren (Reeze et al., 2016);

- Handboek geomorfologisch beekherstel (Makaske en Maas, 2015);

- Waternood (Runhaar \& Hennekens 2014).

Ten slotte leggen we een verband tussen het bereik van het waterpeil in de beek in de referentiesituatie en de potenties voor grondwaterafhankelijke vegetaties in het beekdal. Daarvoor zijn eerst op basis van de landschapsecologische positie de relevante vegetatietypen geselecteerd. Vervolgens zijn de abiotische randvoorwaarden van deze potentiële vegetatietypen vergeleken met voorjaars- en najaarspeilen van bijpassende KRW-beektypen/moerasbeken. 


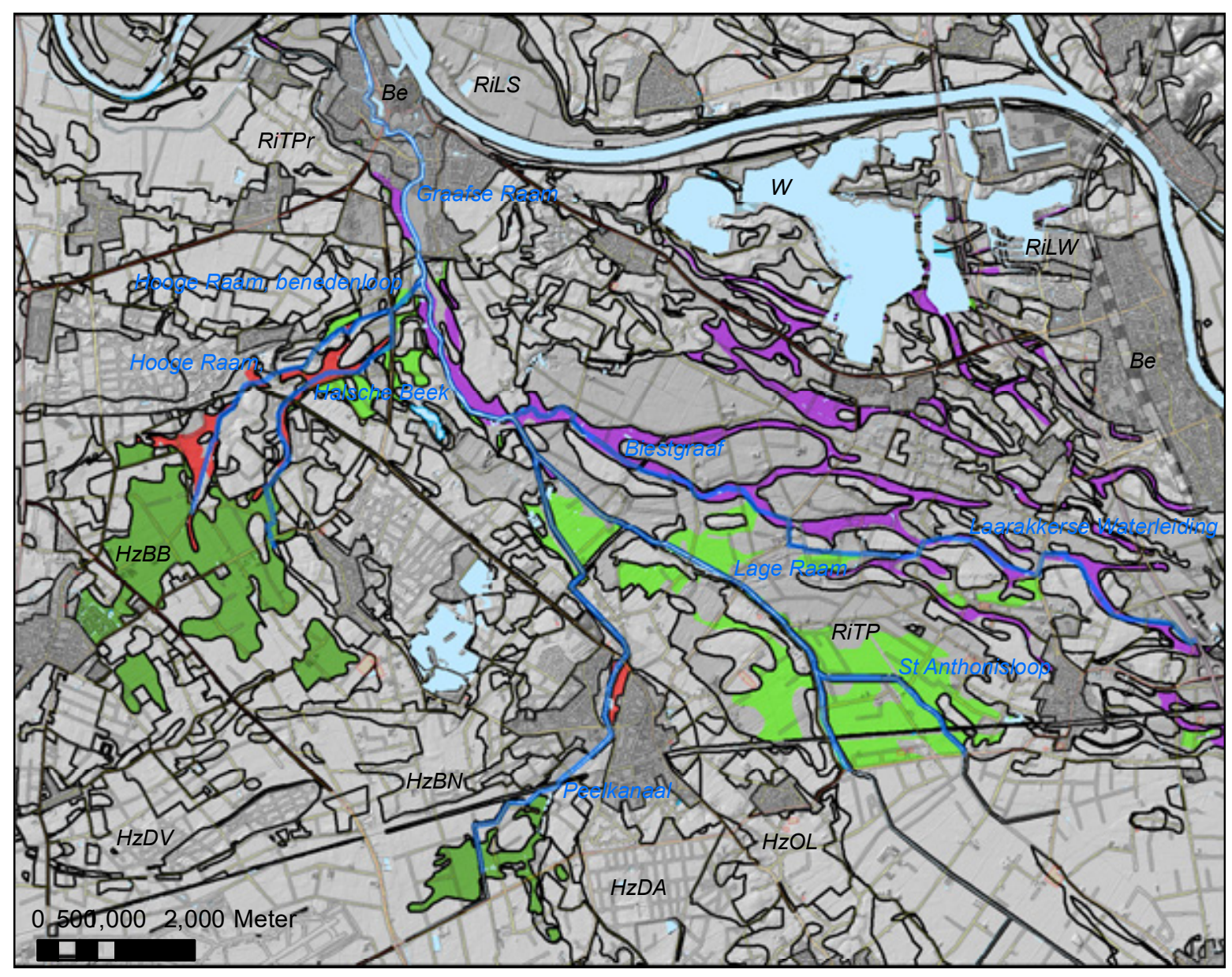

Voorkomen referenties

Bovenstroomse kwelmoerassen en bronbeken
Snel stromende terrasbeken met zandbedding
Kwelmoeras hellingvoet terrasrand

Moerasbeek in verlande restgeul in het rivierenlandschap

Figuur 4-1 Ligging van de referenties in de Raamvallei.

De referenties voor de Raamvallei en de ligging van de gebieden waar deze referenties op van toepassing zijn, zijn grotendeels gebaseerd op de kaart Fysisch-Geografische typen (Figuur 3-1, 3-2, 3-5 en 3-6). Uit deze kaart zijn alleen die eenheden geselecteerd die landschapsecologisch gezien (nog) de kenmerken dragen van een beeksysteem. De donkergroene gebieden op de kaart zijn de bovenstroomse kwel- en brongebieden op de Peelhorst. In rood zijn de natuurlijke beekdalen van de Hooge Raam, de Halsche Beek en het Peelkanaal weergegeven; in paars de restgeulen in het rivierterras. Ten slotte is in lichtgroen het kwelmoeraszone aan de voet van de terrasrand weergegeven. Zoals de kaart laat zien, is het kwelmoeras geen aaneengesloten gebied, maar een zone waar lokaal de potenties voor deze referentie aanwezig zijn. Van de Hooge Raam, de Halsche Beek, de Graafsche Raam en de Biestgraaf kan gezegd worden dat het waterlopen zijn die landschapecologisch gezien in een natuurlijke beekdalpositie liggen. Wat betreft de Lage Raam geldt een wat andere situatie. Het oorspronkelijke kwelmoeras aan de voet van de terrasrand (broek) strekte zich voor 1850 uit tot Haps en Wanrooij/Rijkevoort. Naar alle waarschijnlijk zal dit kwelgebied de kenmerken hebben gehad van het door Verdonschot (et al. (2016)) beschreven 'doorstroommoeras': een moeraszone met weinig verhang dat uitwaaiert over een brede zone met een of meerder kwel-gevoede loopjes die overtollig water afvoeren. Er is geen stagnatie van water, maar een continue stroomafwaarts gerichte waterstroming waardoor geringe veenvorming kan plaatsvinden. Dit uitgestrekte broek is geheel verdwenen en daarmee is ook de landschapsecologische positie van de Lage Raam gewijzigd. De Lage Raam is geworden tot een landbouwwatergang die door het potentiële kwelmoeras op de hellingvoet van de terrasrand loopt. Omdat vanuit het oogpunt van natuurwaarde deze kwelmoerassen prioriteit hebben, is ervoor gekozen deze als referentie te nemen voor het gebied van de Lage Raam. 


\subsubsection{Bovenstroomse kwelmoerassen en bronbeken}

Bovenstroomse kwelmoerassen en brongebieden liggen op plaatsen waar op natuurlijke wijze over een klein of groot oppervlak grondwater uittreedt. Deze kwelgebieden zijn gekoppeld aan glooiende, heuvelachtige gebieden met steile hellingen (terrasrand) waar in de ondergrond een afwisseling is van goed en slecht doorlatende lagen. De hoeveelheid en de kwaliteit van het uitstromende water worden bepaald door grondwaterstroming en grondwaterstand in het inzijg- en kwelgebied. Op basis van het type begroeiing kan onderscheid gemaakt worden tussen weidebronnen en bosbronnen.

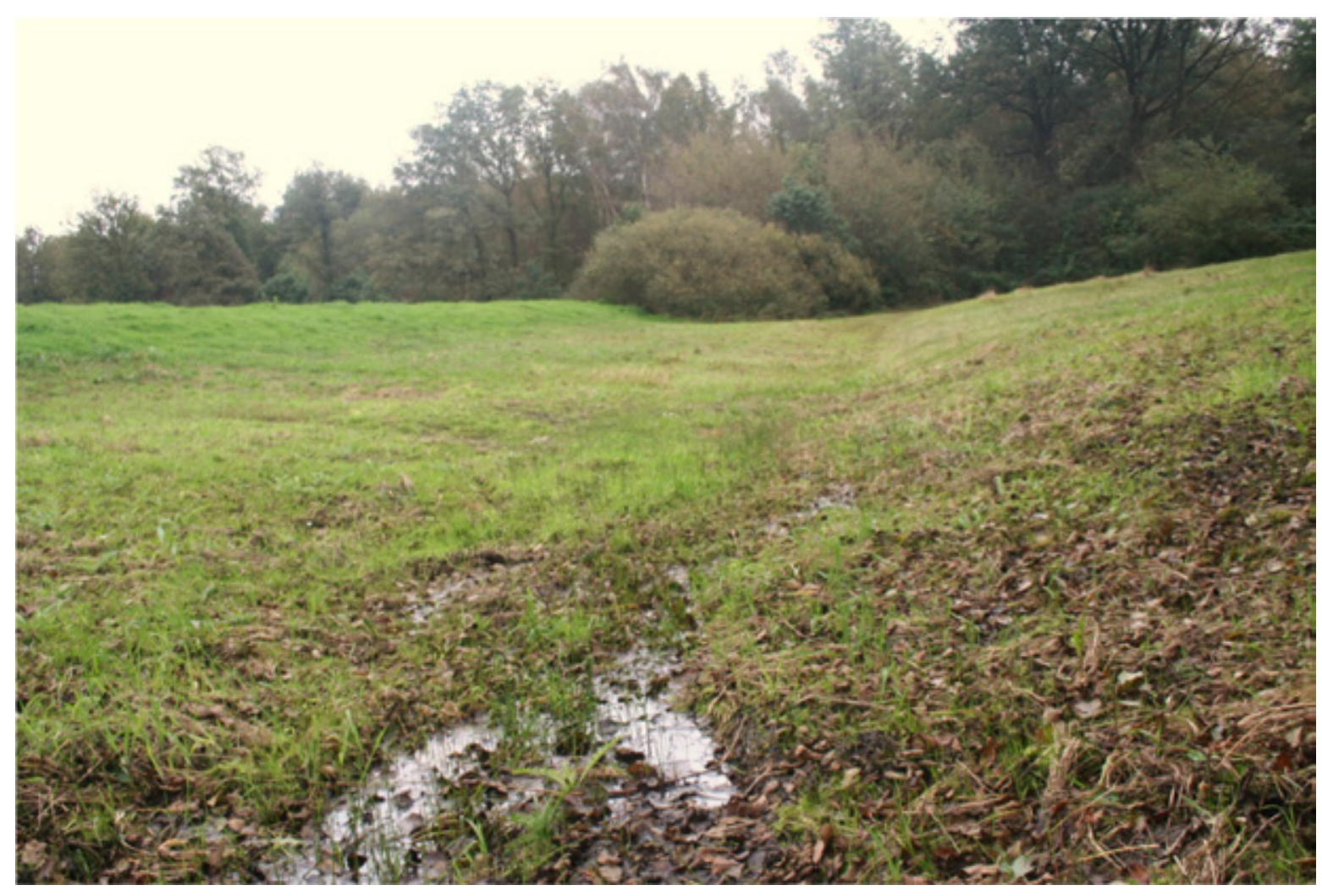

Figuur 4-2 Weidebron in de bovenloop van een beekdal in Twente. 
Tabel 4-1 Kenmerken natuurlijke referentie bovenstroomse kwelmoerassen en bronbeken.

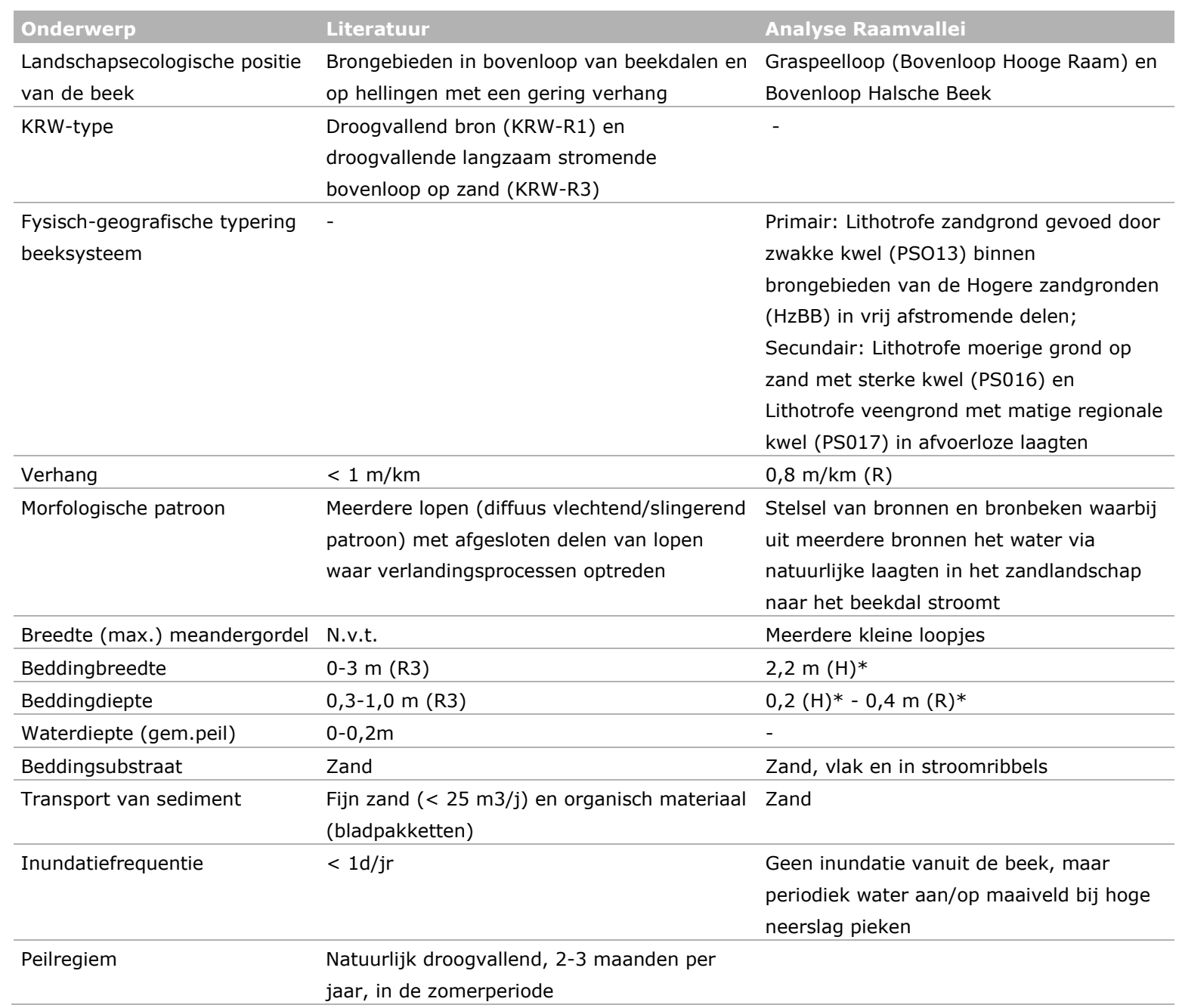

$*(H)=$ Halsche Beek; $(\mathrm{R})=$ Hooge Raam

\section{Realisatiekansen potentiële vegetaties}

De realisatiekansen voor de potentiële vegetaties voor deze referentie zijn gebaseerd op de landschapsecologische positie en de kenmerken van de KRW-typen 'droogvallend bron' (R1) en 'droogvallende langzaam stromende bovenloop op zand' (KRW-R3).

Tabel 4-2 is een selectie van de potentiële vegetaties bij de FG-typen van de bovenstroomse kwelmoerassen. De groengekleurde plantengemeenschappen passen goed bij het peilverloop van de droogvallende bronnen (KRW-type R1), de blauwgekleurde gemeenschappen sluiten meer aan bij het peilverloop van droogvallende langzaam stromende bovenloop op zand (KRW-type R3, zie Figuur 4-3 en Figuur 4-4). 
Tabel 4-2 Selectie potentiële vegetaties bij de FG-typen van de bovenstroomse kwelmoerassen (Brongebieden van de Hogere zandgronden).

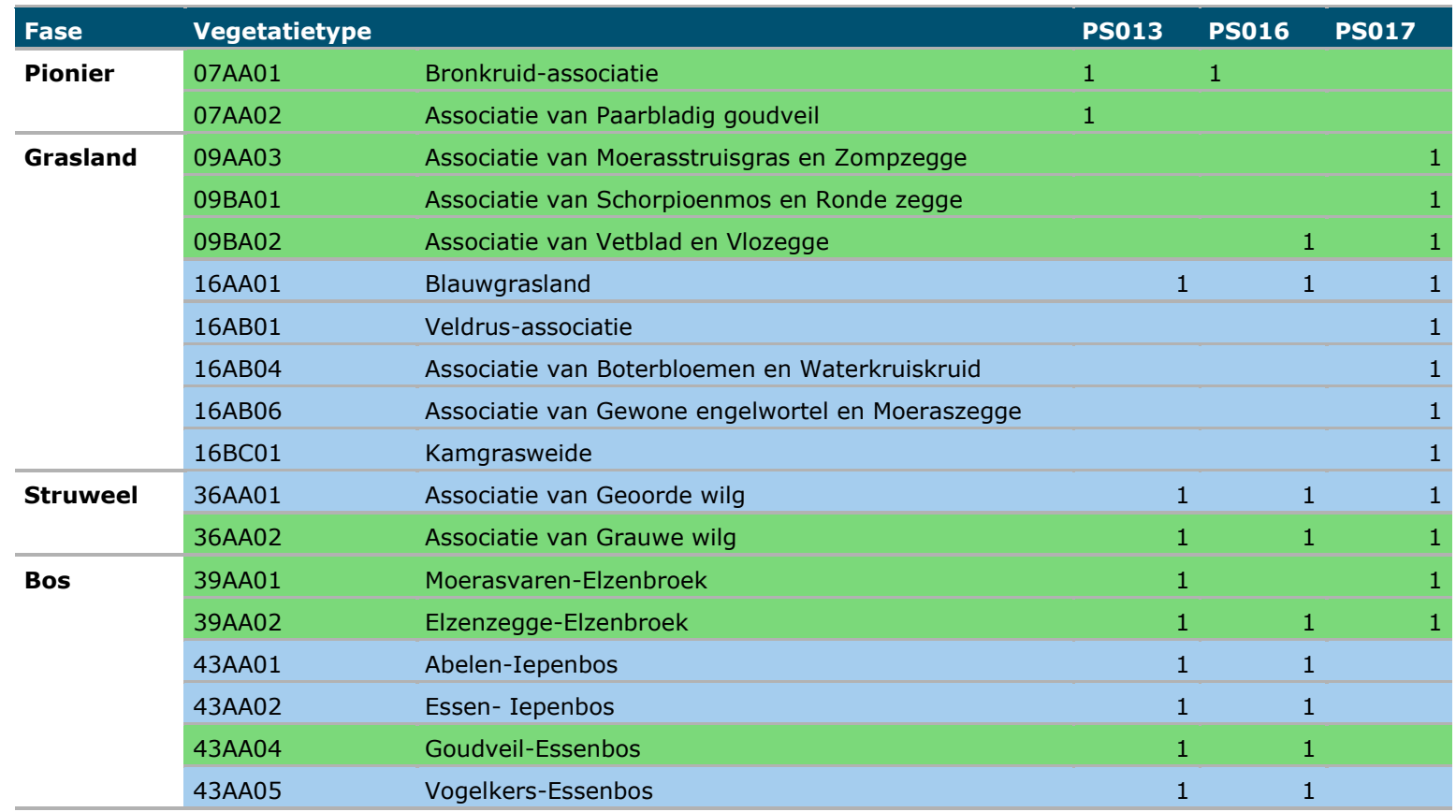

In Figuur 4-3 en 4-4 zijn de abiotische randvoorwaarden voor GVG en GLG voor de potentiële vegetaties binnen bovenstroomse kwelmoerassen - voor de successiefasen grasland, struweel en bos - vergeleken met respectievelijk de voorjaars- en de najaarspeilen (t.o.v. maaiveld) voor het referentiebeeld voor droogvallende bronnen en voor droogvallende langzaam stromende bovenloop op zand, KRW-typen R1 en R3. De abiotische randvoorwaarden zijn geselecteerd uit Waternood (Runhaar \& Hennekens, 2014) en de KRW-peilen uit Reeze et al. (2016).

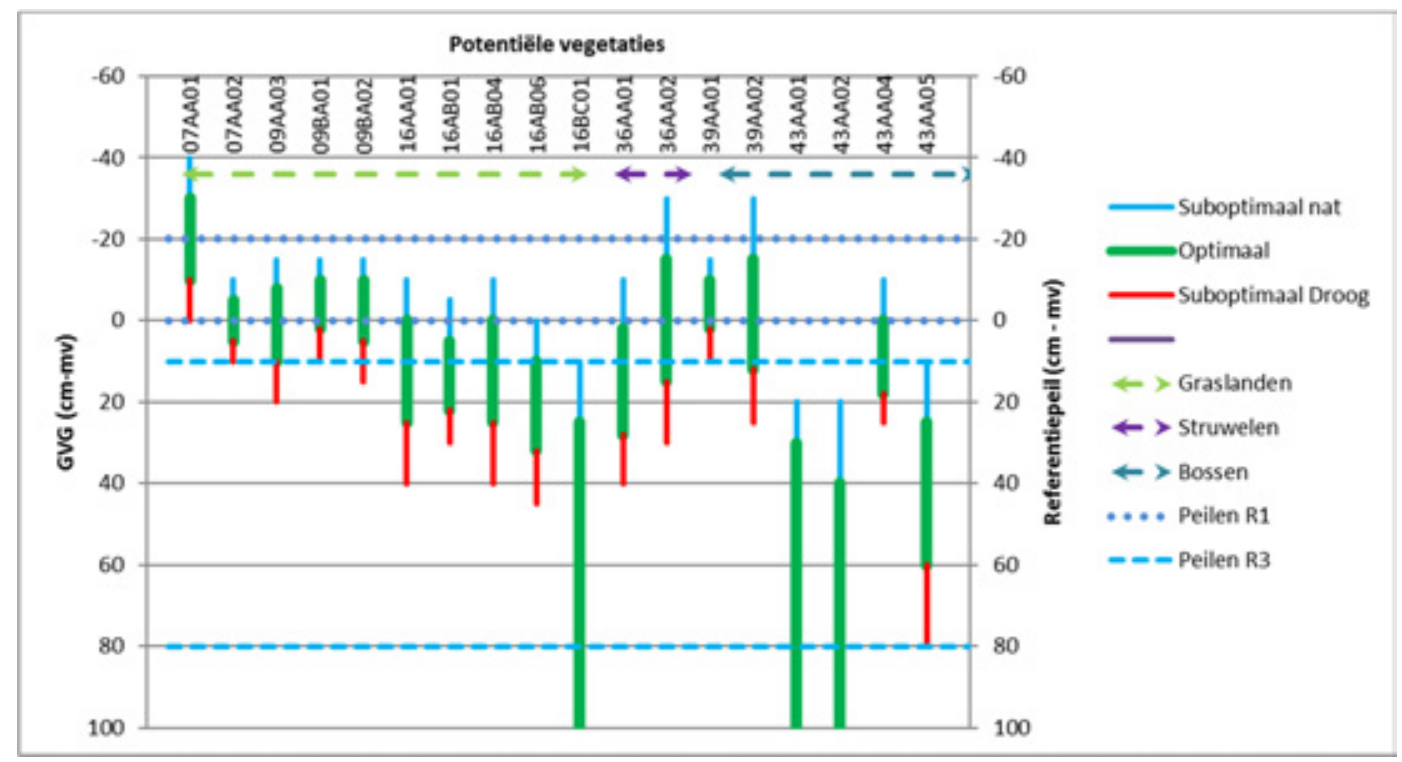

Figuur 4-3 Abiotische randvoorwaarden voor GVG voor de potentiële vegetaties binnen bovenstroomse kwelmoerassen, voor de successiefasen grasland, struweel en bos; vergeleken met de voorjaarspeilen (t.o.v. maaiveld) voor het referentiebeeld voor droogvallende bronnen en voor droogvallende langzaam stromende bovenloop op zand KRW-typen R1 en R3 (zie tekst voor verantwoording). 


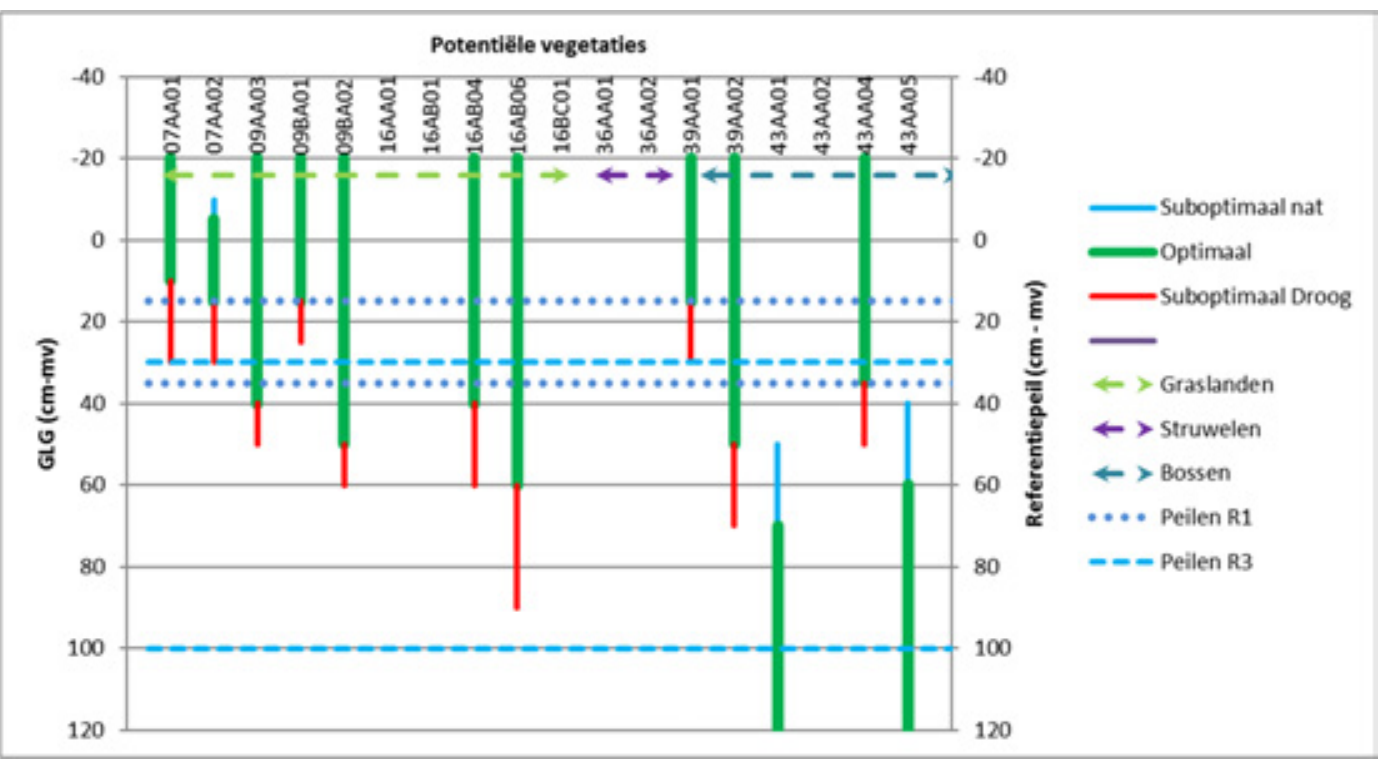

Figuur 4-4 Abiotische randvoorwaarden voor GLG voor de potentiële vegetaties binnen bovenstroomse kwelmoerassen, vergeleken met de najaarspeilen (t.o.v. maaiveld) voor het referentiebeeld voor KRW-typen R1 en R3 (zie 4-3 voor verantwoording).

Voor delen van de bovenstroomse kwelmoerassen waar het peilverloop overeenkomt met dat van KRW-type R1 (droogvallende bron), kan op de natste, venige plekken een aantal moerasvegetaties verwacht worden van Klasse der kleine zeggen (09), die bij afwezigheid van een vegetatiebeheer (maaien, begrazen) zullen overgaan in wilgstruwelen met grauwe wilg (36AA02) of elzenbroekbos (39AA). Bronvegetaties (07AA) komen eventueel in de allernatste delen voor. In de minst natte delen kan bosontwikkeling hier leiden naar goudveil-essenbos (43AA04).

In de nabijheid van bovenloopjes die het kwelmoeras ontwateren (KRW-type R3, 'droogvallende langzaam stromende bovenloop op zand'), zullen de korte vegetaties bij beweiding vooral het karakter hebben van kamgrasweide (16BC01) of drogere graslanden. Alleen in de natste delen is hier een ontwikkeling naar blauwgrasland (16AA01) of dotterbloemhooiland (16AB) mogelijk. In deze natte delen zal bij uitblijven van beheer een ontwikkeling naar struweel van geoorde wilg (36AA01) en drogere varianten van Elzenzegge-elzenbroek (39AA02) mogelijk zijn. In de drogere delen moet gedacht worden aan diverse bostypen uit het verbond van Els en Vogelkers (43Aa).

\subsubsection{Snelstromende terrasbeek met zandbedding}

Terrasbeken komen voor in matig tot diep ingesneden dalen met aan weerszijden steilranden, op de overgang van een rivierterras naar een lager gelegen terras of dalvlakte. Het beekdal heeft het reliëf van een actief meanderende beek, maar langs de beek ontbreken oeverwallen vanwege de beperkte ruimte. De beek heeft een ondiepe meanderende loop, die sterk varieert in breedte en diepte. De bedding bestaat uit (grof) zand. Bij een diepe insnijding in het terras wordt het patroon van meanderen onderdrukt en manifesteert de morfodynamiek zich in bankvorming in een rechte tot slingerende beekloop (Makaske en Maas, 2015). De voeding van de beek bestaat uit grondwater uit het bovengelegen kwelmoeras en uit neerslag. 


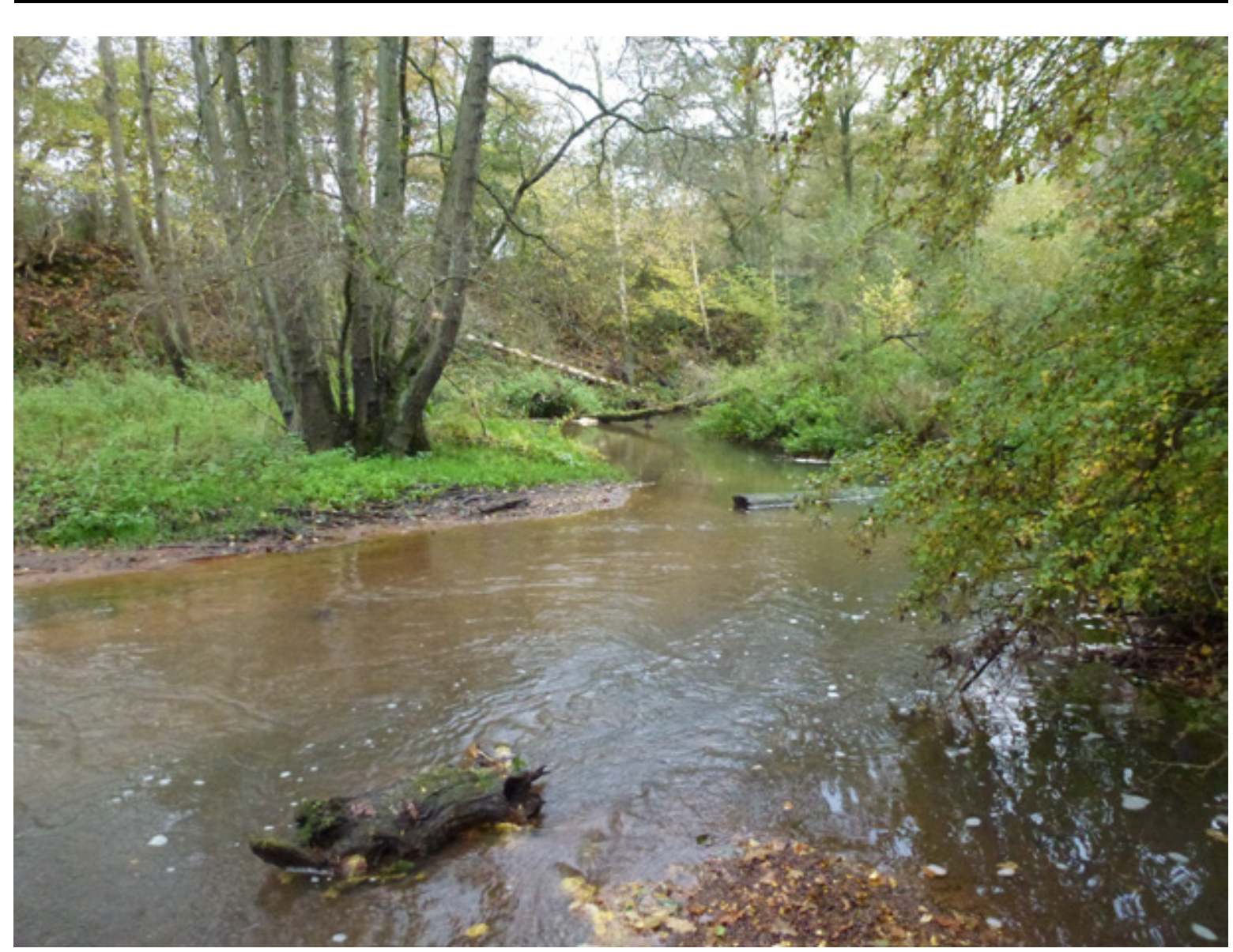

Figuur 4-5 Geldersch-Nierskanaal, referentie voor snelstromende terrasbeken met zandbedding.

Tabel 4-3 Kenmerken natuurlijke referentie snelstromende terrasbeek met een zandbedding.

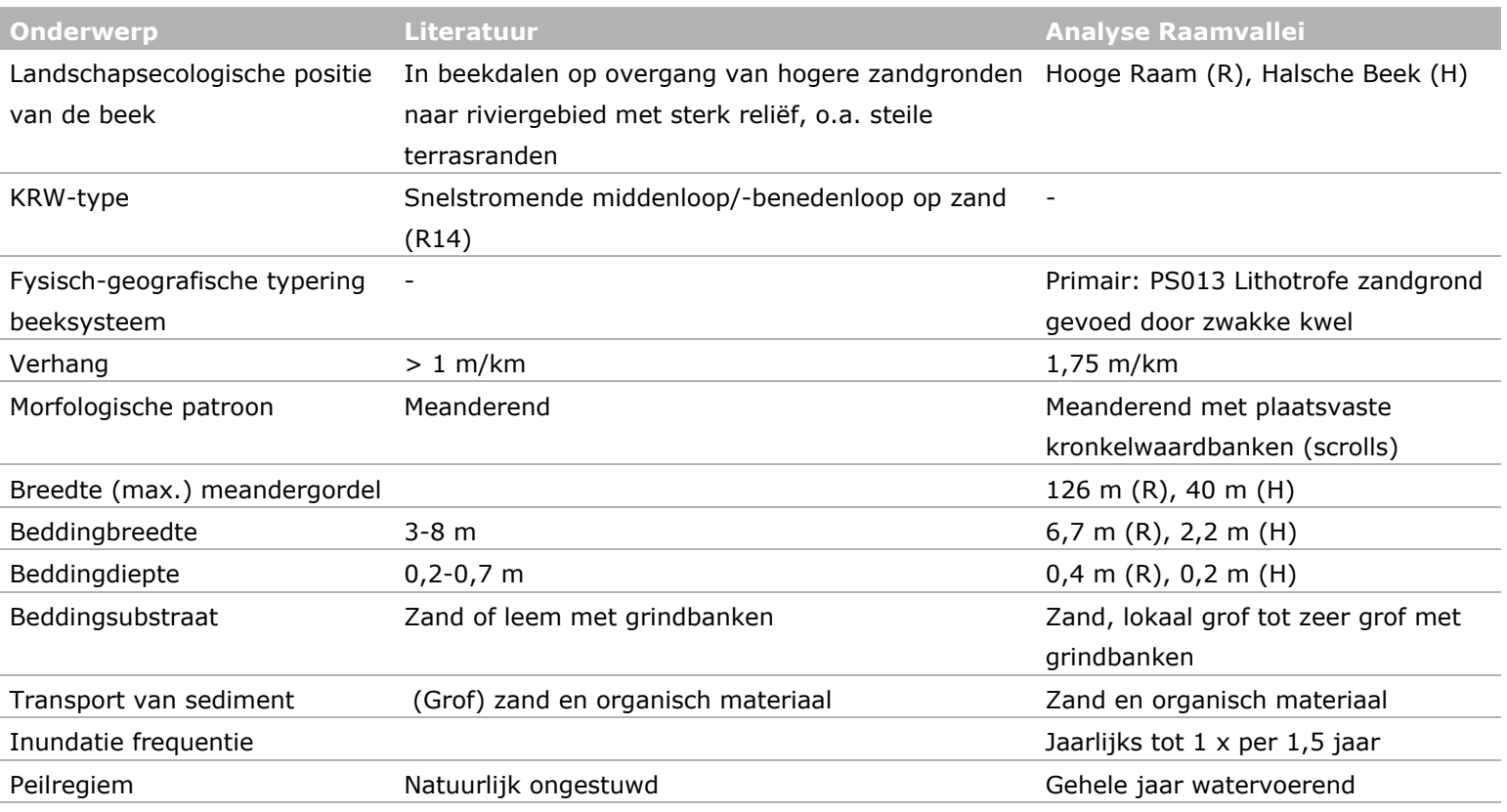

\section{Realisatiekansen potentiële vegetaties}

De realisatiekansen voor de potentiële vegetaties voor deze referentie zijn gebaseerd op de landschapsecologische positie en de kenmerken van het KRW-type snelstromende middenloop/benedenloop op zand (R14). 
Tabel 4-4 is een selectie potentiële vegetaties bij de FG-typen van de snelstromende terrasbeek met een zandbedding. De groengekleurde plantengemeenschappen passen goed bij het peilverloop van de snelstromende middenloop/-benedenloop op zand (KRW type R14), voor de oranje gekleurde gemeenschappen zijn de grondwaterstanden langs de beek te ondiep (zie Figuur 4-6 en 4-7).

Tabel 4-4 Selectie potentiële vegetaties bij de FG-typen van de snelstromende zandbeken van terras naar rivierenlandschap.

\begin{tabular}{rllr} 
Fase & Vegetatietype & PS013 \\
\hline Grasland & 16AA01 & Blauwgrasland & 1 \\
\hline Struweel & 36AA01 & Associatie van Geoorde wilg & 1 \\
& 36AA02 & Associatie van Grauwe wilg & 1 \\
Bos & 39AA01 & Moerasvaren-Elzenbroek & 1 \\
& 39AA02 & Elzenzegge-Elzenbroek & 1 \\
& $43 \mathrm{AA01}$ & Abelen-Iepenbos & 1 \\
& $43 \mathrm{AA02}$ & Essen- Iepenbos & 1 \\
& 43AA04 & Goudveil-Essenbos & 1 \\
& 43AA05 & Vogelkers-Essenbos & 1 \\
\hline
\end{tabular}

De abiotische randvoorwaarden voor GVG en GLG voor de potentiële vegetaties langs snelstromende terrasbeken met een zandbedding, vergeleken met respectievelijk de voorjaars- en najaarspeilen (t.o.v. maaiveld) voor KRW-type R14, zijn weergegeven in Figuur 4-6 en 4-7.

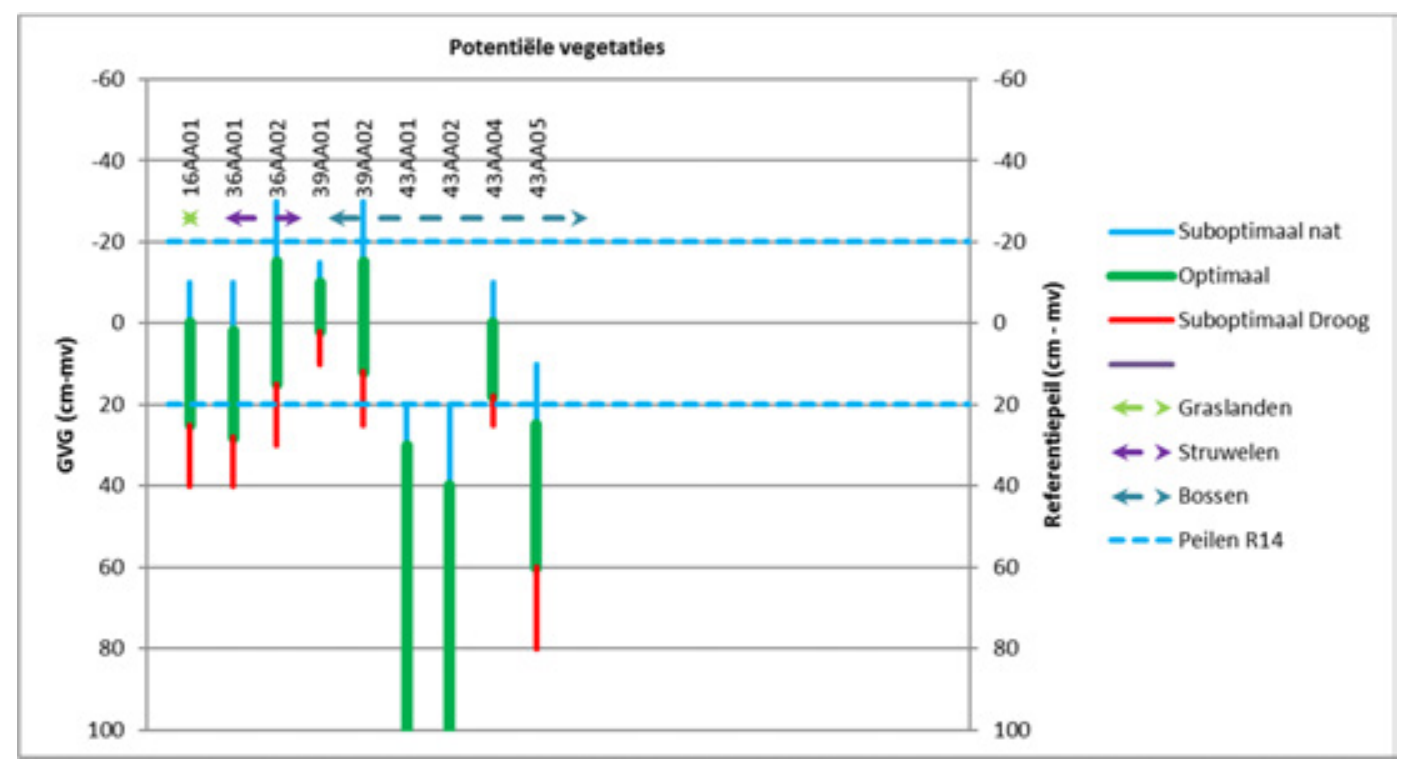

Figuur 4-6 Abiotische randvoorwaarden voor GVG voor de potentiële vegetaties langs snelstromende zandbeken van terras naar rivierenlandschap, vergeleken met de voorjaarspeilen (t.o.v. maaiveld) voor het referentiebeeld voor KRW-type R14. 


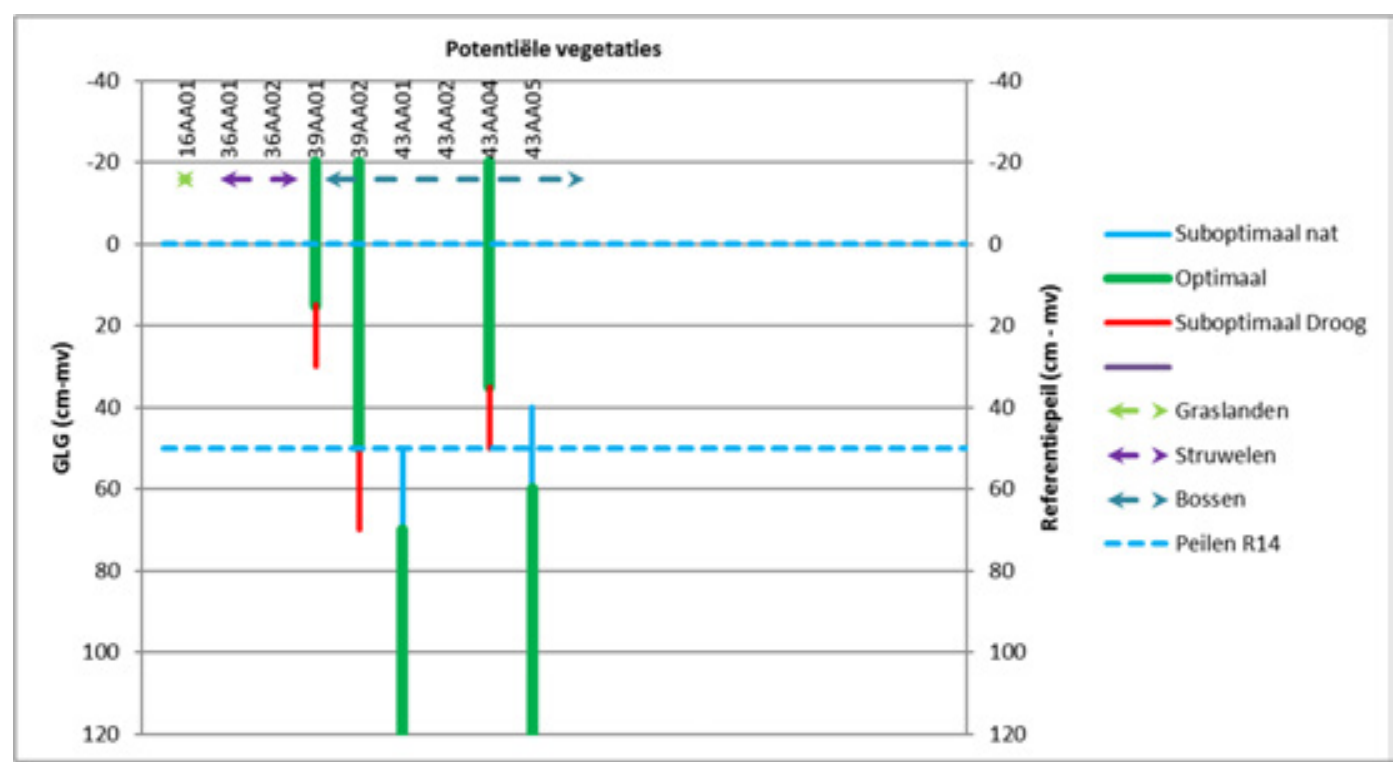

Figuur 4-7 Abiotische randvoorwaarden voor GLG voor de potentiële vegetaties langs snelstromende zandbeken van terras naar rivierenlandschap, vergeleken met de najaarspeilen (t.o.v. maaiveld) voor het referentiebeeld voor KRW-type $R 14$.

Binnen deze referentie passen de dimensies van snelstromende middenloop/-benedenloop op zand (KRW-type R14). Voor de terrestrische natuur langs de beek geldt bij de referentiepeilen dat hier bij een graslandbeheer vooral blauwgrasland verwacht (16AA01) kan worden. Bij afwezigheid van beheer is via wilgenstruwelen (36AA) een ontwikkeling richting elzenbroekbos (39AA) te verwachten en op iets drogere delen Goudveil-essenbos (43AA04). Voor de andere bostypen die bij FG-type PS013 passen, zijn de groeiplaatsen langs de beek te nat. Verder van de beek, iets hoger op de gradiënt, kunnen deze wel voorkomen.

\subsubsection{Kwelmoeras hellingvoet terrasrand}

Het kwelmoeras aan de hellingvoet bestaat uit plaatsen waar onophoudelijk grondwater opwelt (KRWR2). Het terrein heeft een licht hellend, zwak reliëf. De bron heeft vaak het karakter van een bospoel die de oorsprong vormt van een beek. Vanwege het geringe verhang en de landschapsecologische setting, heeft de beek het karakter van kleine middenloop/benedenloop op zand (KRW-R5) of klei (KRW-R6). De beek heeft een recht tot slingerend verloop met steile, lage oevers. Een (broek)boslandschap is kenmerkend voor dit beektype. 


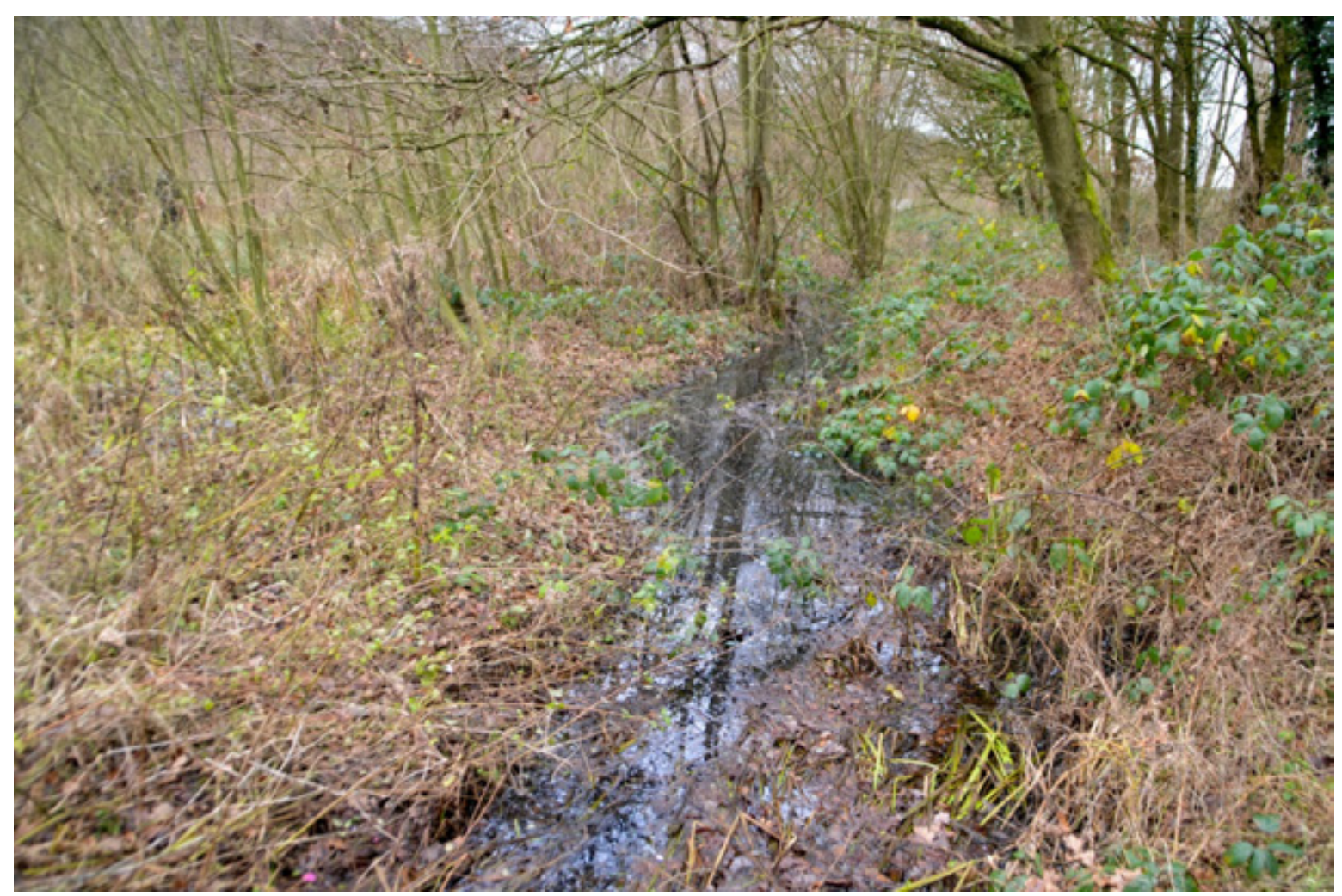

Figuur 4-8 Bronnetjesbos bij Ubbergen, referentie voor een kwelmoeras aan de hellingvoet. Het water uit de bronnen wordt via een beekje afgevoerd naar 'Het Meer'.

Tabel 4-5 Kenmerken natuurlijke referentie kwelmoeras hellingvoet terrasrand.

\begin{tabular}{|c|c|c|}
\hline Onderwerp & Literatuur & Analyse Raamvallei \\
\hline $\begin{array}{l}\text { Landschapsecologische positie } \\
\text { van de beek }\end{array}$ & $\begin{array}{l}\text { Grondwater gevoede doorstroommoerassen op } \\
\text { rivierterras }\end{array}$ & Lage Raam/Biestgraaf \\
\hline KRW-type & $\begin{array}{l}\text { Permanente bron (R2), overgaand in } \\
\text { Langzaam stromende midden- en benedenloop op } \\
\text { zand (R5) of op klei (R6) }\end{array}$ & \\
\hline $\begin{array}{l}\text { Fysisch-geografische typering } \\
\text { beekdal }\end{array}$ & & $\begin{array}{l}\text { PS040 Matig basenarme Oude } \\
\text { rivierkleigronden } \\
\text { PS036C (Rivier)zandgronden met } \\
\text { een kleidek (Kalkarm) } \\
\text { PS013 Lithotrofe zandgrond gevoed } \\
\text { door zwakke kwel }\end{array}$ \\
\hline Verhang & $<1 \mathrm{~m} / \mathrm{km}$ & $0,28 \mathrm{~m} / \mathrm{km}(\mathrm{R})$ \\
\hline Morfologische patroon & & $\begin{array}{l}\text { Geen meandering, in het bereik van } \\
\text { de rechte/ zwak slingerende } \\
\text { waterlopen }\end{array}$ \\
\hline Breedte (max.) meandergordel & & N.v.t. \\
\hline Beddingbreedte & 3-8 m (R5) en 8-25 m (R6) & $6,1-11,5 \mathrm{~m}(\mathrm{LR})$ \\
\hline Beddingdiepte & $0,6-1,0 \mathrm{~m}$ & $0,7-1,1 \mathrm{~m}(\mathrm{LR})$ \\
\hline Beddingsubstraat & Zand en/of klei & Fijn en matig grof zand \\
\hline Transport van sediment & Fijn zand en klei & Fijn zand en klei \\
\hline Inundatie freq. & $>10$ dagen/jaar & \\
\hline Peilregiem & Natuurlijk, ongestuwd & \\
\hline
\end{tabular}

\section{Realisatiekansen potentiële vegetaties}

Tabel 4-6 is een selectie potentiële vegetaties bij de FG-typen van de kwelmoerassen aan de terrasvoet. De groengekleurde plantengemeenschappen passen goed bij het peilverloop van de permanente bronnen (KRW-type R2), de blauwgekleurde gemeenschappen sluiten meer aan bij het 
peilverloop van 'Langzaam stromende midden- en benedenloop op zand of op klei' (KRW-type R5/6, zie Figuur 4-9 en 4-10). De oranje gekleurde gemeenschappen horen bij drogere standplaatsen binnen dit landschap, de referentie is hiervoor te nat.

Tabel 4-6 Selectie potentiële vegetaties bij de FG-typen van de kwelmoerassen aan de terrasvoet (toelichting zie tekst).

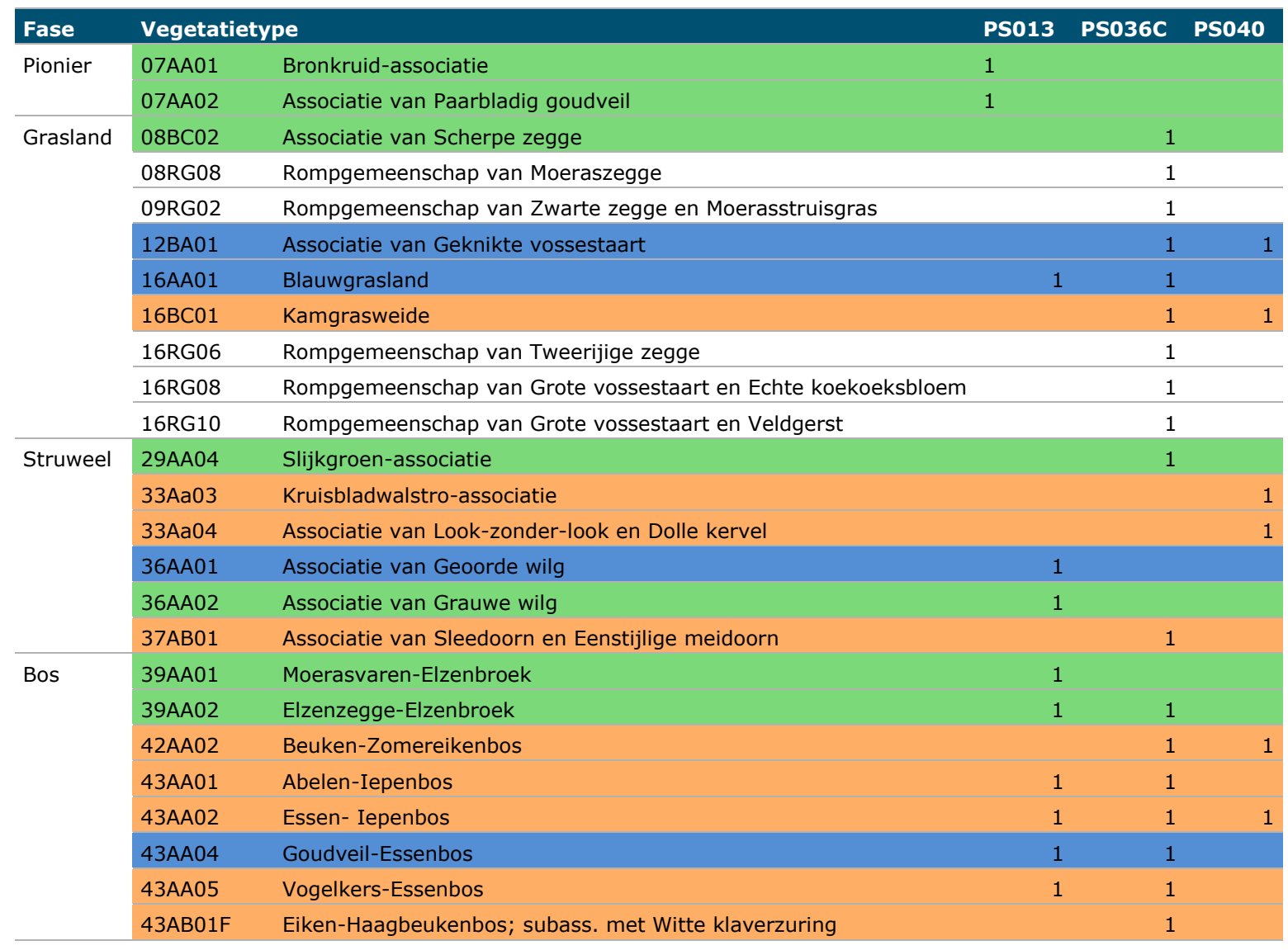

De abiotische randvoorwaarden voor GVG en GLG voor de potentiële vegetaties van kwelmoerassen aan de terrasvoet zijn vergeleken met respectievelijk de voorjaars- en najaarspeilen (t.o.v. maaiveld) voor het referentiebeeld voor KRW-typen R2 en R5/6 in Figuur 4-9 en 4-10. 


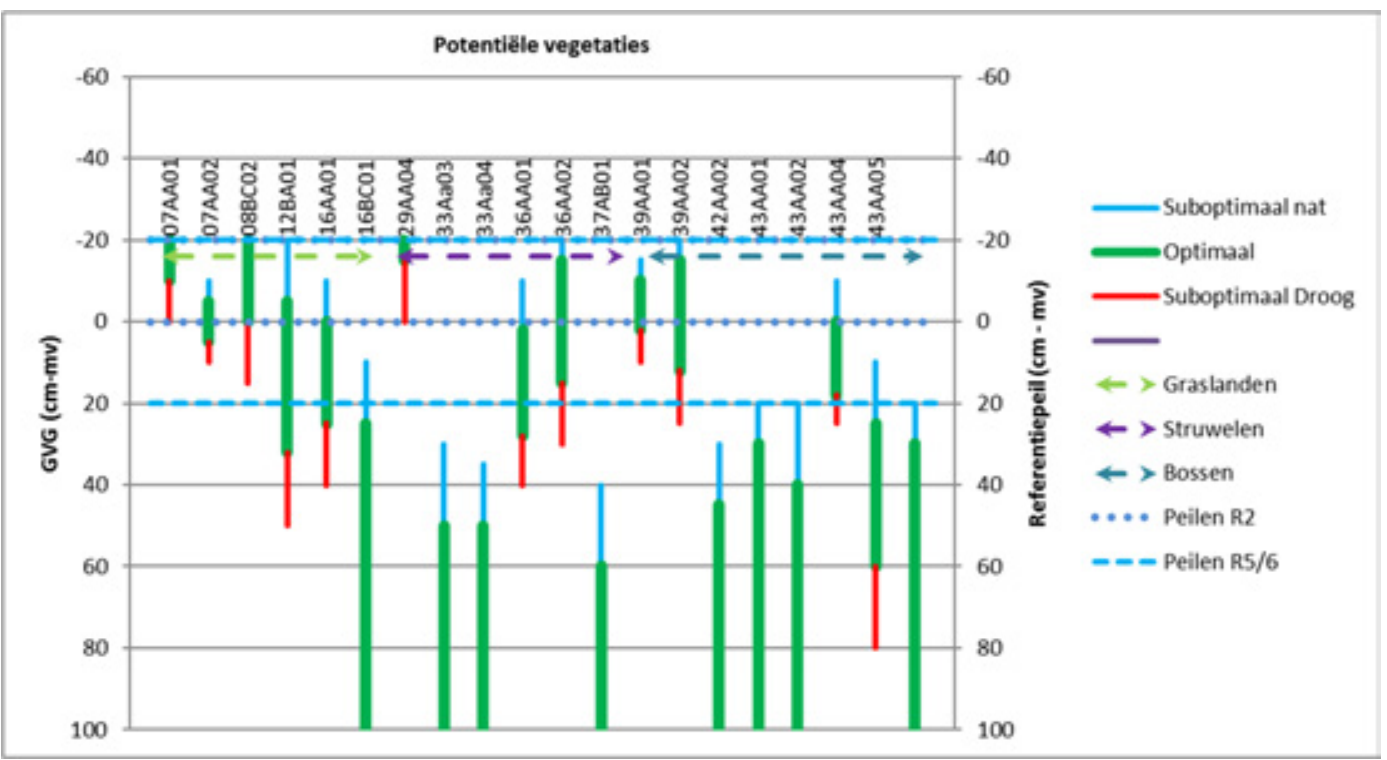

Figuur 4-9 Abiotische randvoorwaarden voor GVG voor de potentiële vegetaties van kwelmoerassen aan de terrasvoet, vergeleken met de voorjaarspeilen (t.o.v. maaiveld) voor het referentiebeeld voor KRW-typen $R 2$ en $R 5 / 6$.

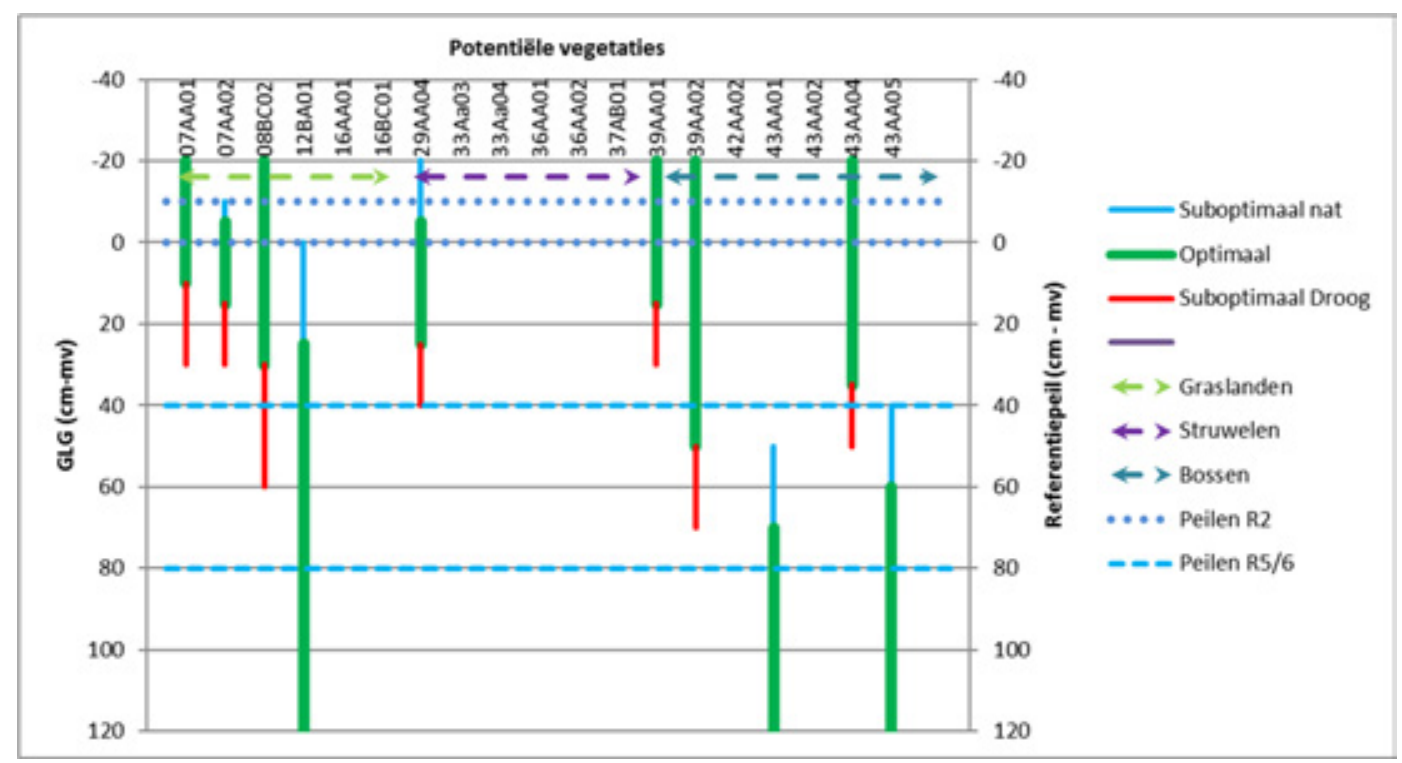

Figuur 4-10 Abiotische randvoorwaarden voor GLG voor de potentiële vegetaties van kwelmoerassen aan de terrasvoet, vergeleken met de najaarspeilen (t.o.v. maaiveld) voor het referentiebeeld voor KRW-typen $R 2$ en $R 5 / 6$.

Het kwelmoeras aan de hellingvoet van de terrasrand omvat het kwel-gevoede deel van de zand- en kleigronden op het pleistocene rivierterras. Hier komen deels dezelfde Fysisch-Geografische eenheden voor (PS036C en PS040) als op grotere afstand van de terrasrand, maar daar is de kwelinvloed minder sterk aanwezig. In deze kwelzone treedt kwelwater vanuit de Peelhorst uit via permanente bronnen (R2) en verzamelt zich in beekjes (R5/R6) die afstromen naar lagere delen op het pleistocene rivierterras. In de omgeving van de bronnen kunnen zeggemoerasvegetaties verwacht worden (08BC02 en rompgemeenschappen), wilgenstruwelen met Grauwe wilg (36AA02) en elzenbroekbossen (39AA) of Goudveil-essenbos (43AA04).

Wat hoger op de gradiënt en langs de beken kunnen op plekken waar regelmatig inundatie vanuit de beek plaatsvindt graslanden tot ontwikkeling komen met Geknikte vossestaart (12BA01) en op minder voedselrijke plekken die zelden overstromen, blauwgrasland (16AA01). 


\subsubsection{Moerasbeek in verlande restgeul in het rivierenlandschap}

De referentie voor de moerasbeek (R5_m) is geënt op de beschrijving van dit systeem door Verdonschot (et al. (2016)). De moerasbeek vult een natuurlijke, dalvormige laagte of restgeul in het landschap. De moerasbeek ligt in de middenloop of benedenloop van het stroomgebied. In de breedterichting van de laagte kunnen drie zones worden onderscheiden: de beekloop, met aan weerszijden het beekmoeras, geflankeerd door een overstromingszone. De beekloop en het beekmoeras zijn permanent watervoerend, de overstromingszone valt in de zomerperiode droog. De overgang tussen de zones is diffuus. In een periode met geringe afvoer kan de beekloop volgroeien met vegetatie, om daarna bij hogere afvoeren een of meerdere nieuwe lopen te vormen. Het water in het beekmoeras bestaat uit grondwater en (eutroof) oppervlaktewater.

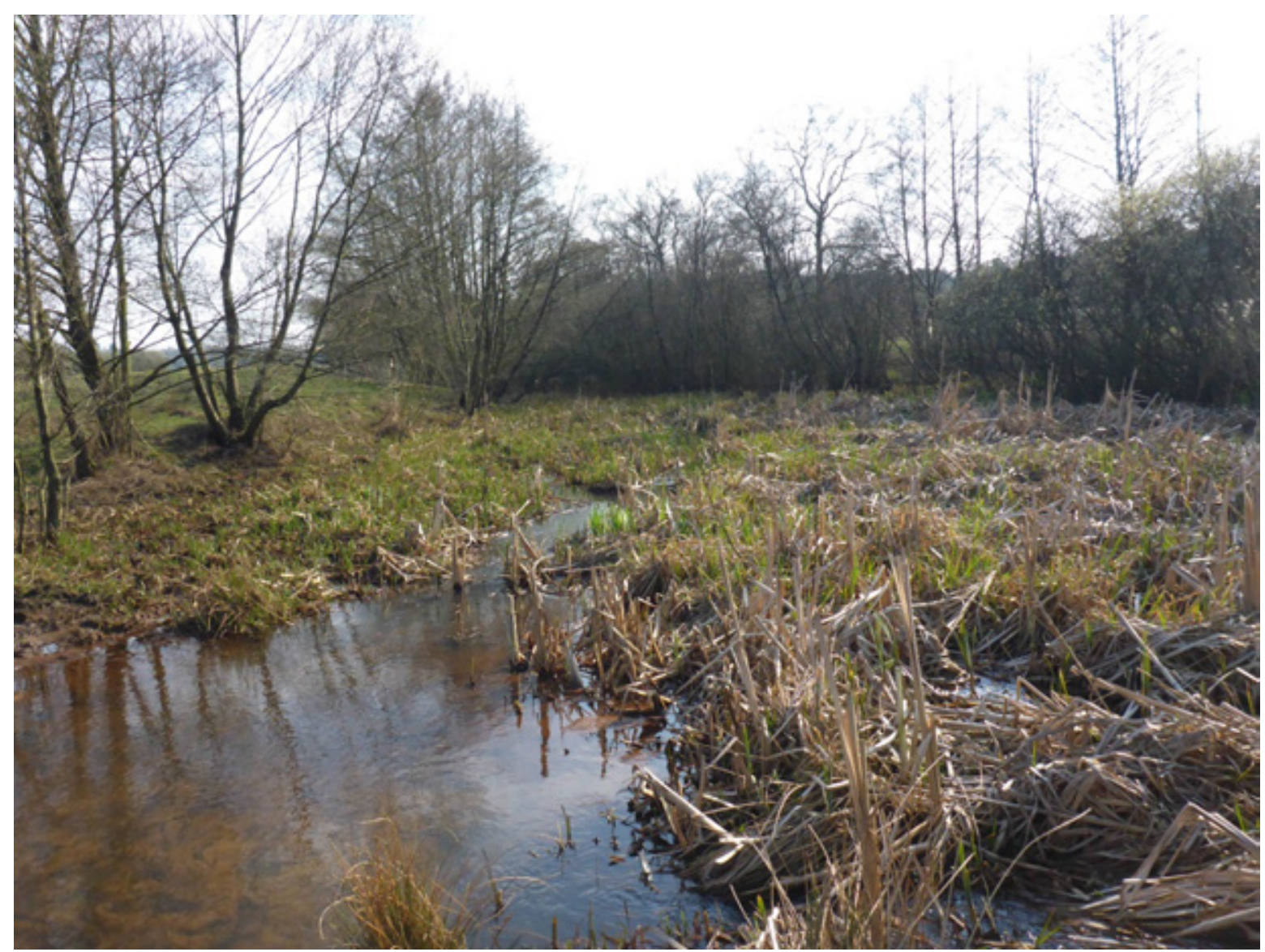

Figuur 4-11 Referentiebeeld voor moerasbeek: beekloop in de oude meander van de Overijsselsche Vecht om het Junner Koeland. 
Tabel 4-7 Kenmerken natuurlijke referentie verlande restgeul in het rivierlandschap.

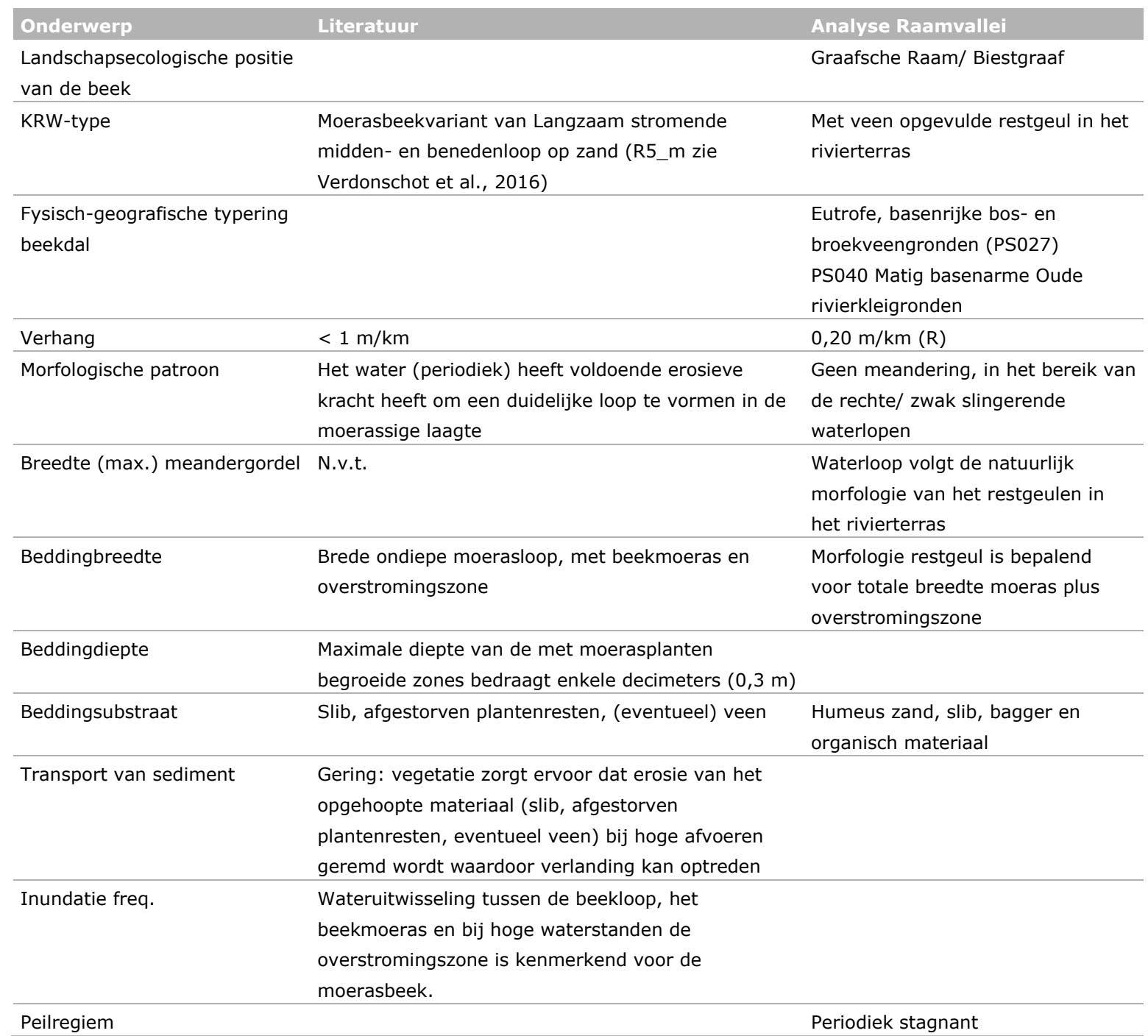

\section{Realisatiekansen potentiële vegetaties}

Tabel 4-8 is een selectie potentiële vegetaties bij de FG-typen van de moerasbeek in een verlande restgeul in het rivierenlandschap. De groengekleurde plantengemeenschappen passen goed bij het peilverloop van de moerasbeken (KRW-type R5_m), voor de lichtgroen gekleurde gemeenschappen zijn de grondwaterstanden suboptimaal, aan de natte kant; voor de lichtblauwe gemeenschappen aan de droge kant (zie Figuur 4-12 en 4-13). De oranje gekleurde gemeenschappen horen bij drogere standplaatsen binnen dit landschap, de referentie binnen de moerasbeek is hiervoor te nat. 
Tabel 4-8 Selectie potentiële vegetaties bij de FG-typen van de moerasbeek in een verlande restgeul in het rivierenlandschap.

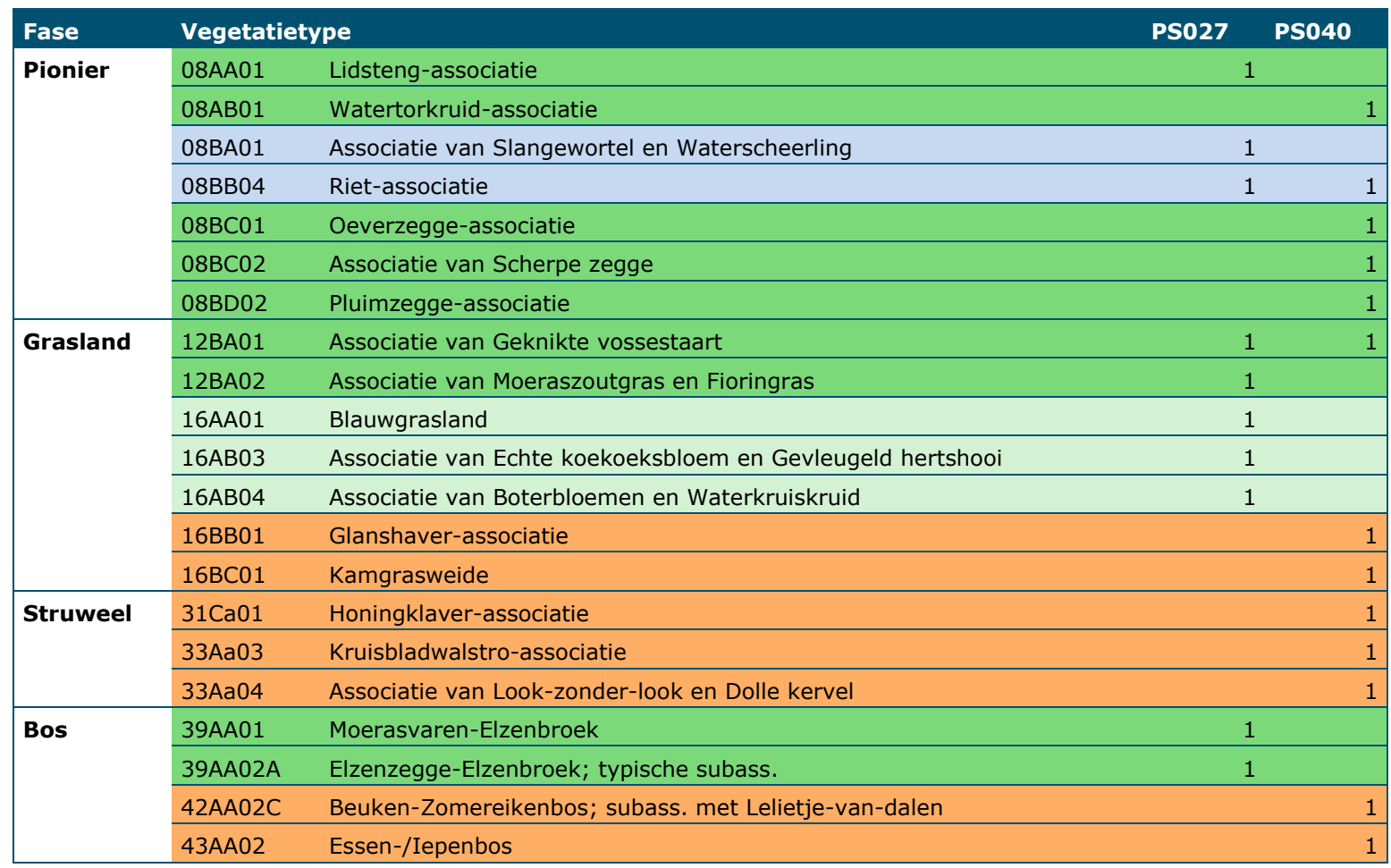

De abiotische randvoorwaarden voor GVG en GLG voor de potentiële vegetaties van de moerasbeek in verlande restgeulen in het rivierenlandschap, vergeleken met respectievelijk de voorjaarspeilen en najaarspeilen (t.o.v. maaiveld) voor het referentiebeeld voor KRW-type R5_m zijn weergegeven in Figuur 4-12 en 4-13.

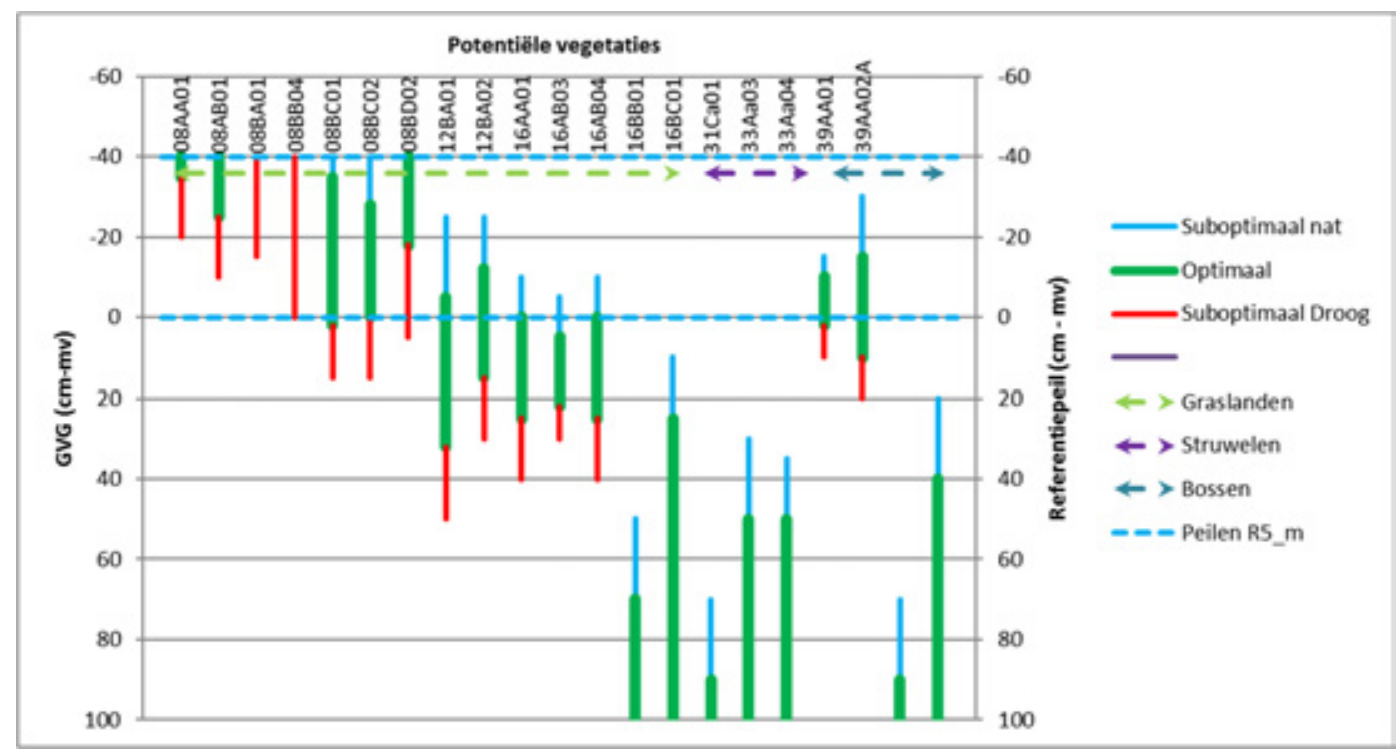

Figuur 4-12 Abiotische randvoorwaarden voor GVG voor de potentiële vegetaties van de moerasbeek in verlande restgeul in het rivierenlandschap, vergeleken met de voorjaarspeilen (t.o.v. maaiveld) voor het referentiebeeld voor KRW-type R5_m. 


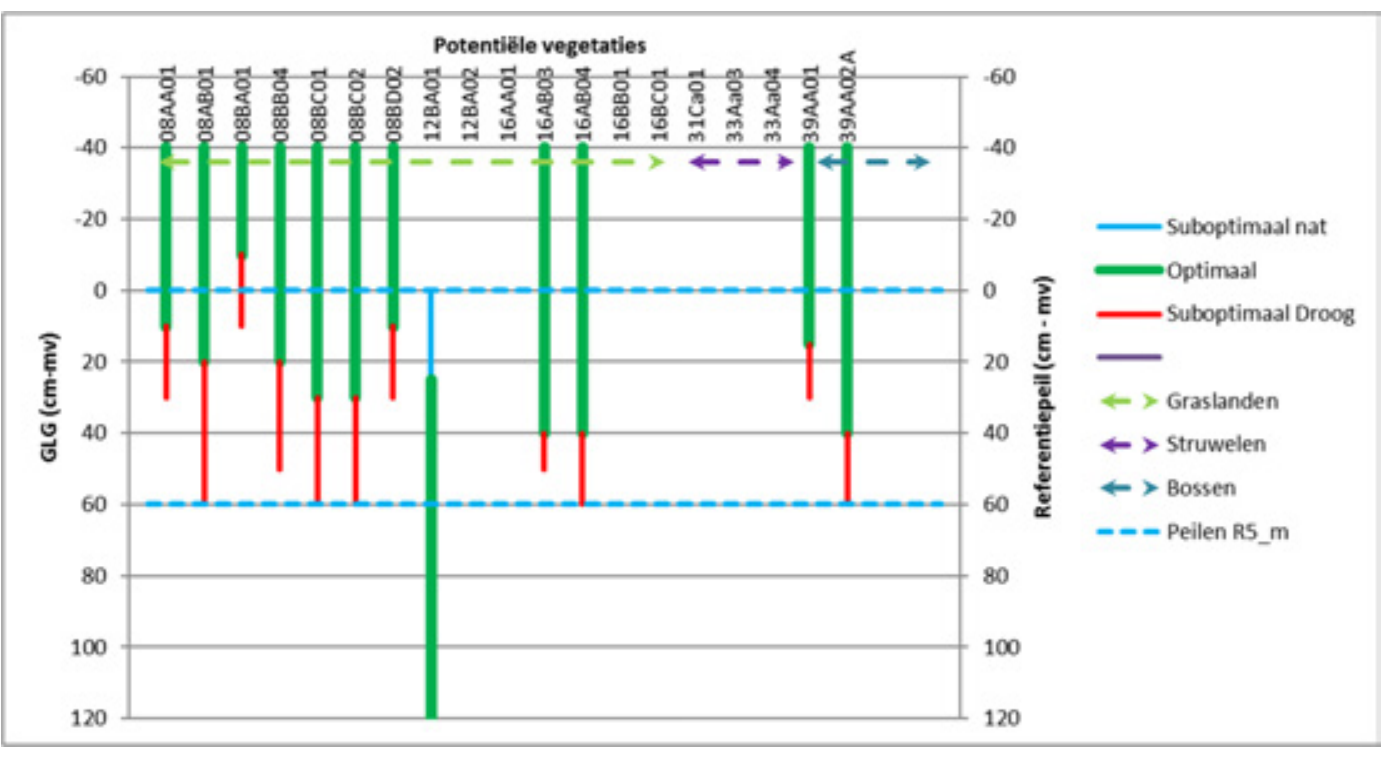

Figuur 4-13 Abiotische randvoorwaarden voor GLG voor de potentiële vegetaties van de moerasbeek in verlande restgeul in het rivierenlandschap, vergeleken met de najaarspeilen (t.o.v. maaiveld) voor het referentiebeeld voor KRW-type R5_m.

Voor deze referentie wordt aangesloten bij de referentie voor moerasbeek als aanvulling op het KRWtype R5 (Verdonschot et al., 2016). Daarbij wordt langs de moerasbeek zowel een beekmoeras als een overstromingszone onderscheiden. Binnen het beekmoeras is een aantal gemeenschappen uit de rietklasse te verwachten, afhankelijk van de waterdiepte, droogval en substraat. Iets verder van de beek, in de overstromingszone bij graslandbeheer, kunnen graslanden uit het zilverschoonverbond (12BA) voorkomen. Bij bosontwikkeling zullen hier elzenbroekbossen (39AA) tot ontwikkeling kunnen komen. Voor blauwgraslanden (16AA) en dotterbloemhooilanden (16AB) zijn de omstandigheden suboptimaal aan de natte kant, zeker voor blauwgrasland. Direct buiten de overstromingszone zijn de omstandigheden gunstiger.

\subsection{Building with Nature-maatregelen in de Raamvallei}

In deze paragraaf wordt een aantal BwN-maatregelen genoemd die ingezet kunnen worden om van de actuele situatie in de Raamvallei te bewegen in de richting van de geschetste referentiebeelden. Belangrijk is dat men zich realiseert dat geschetste referentiebeelden voor de Raamvallei niet onafhankelijk van elkaar, maar alleen in samenhang kunnen worden ontwikkeld. Met andere woorden: (bovenstrooms) kwelmoeras, snelstromende terrasbeek en moerasbeek in de benedenloop vormen een samenhangende referentie voor de Raamvallei. Voor het realiseren van een dergelijke referentie op systeemniveau, is een planproces nodig dat betrekking heeft en uitgaat van een visie op het gehele beeksysteem. Vanuit een visie op stroomgebiedsniveau kunnen bouwstenen worden geïdentificeerd voor beekherstel voor de verschillende beektrajecten (Wolfert et al., 2009). Per beektraject en bouwsteen kan vervolgens uit het BwN-maatregelenoverzicht een maatregelenpakket worden samengesteld. De lijst is overigens niet uitputtend en wordt idealiter in het kader van programma Lumbricus verder aangevuld en getoetst in veldexperimenten.

\section{Maatregelen Bovenstroomse kwelmoerassen}

- bodemverhoging van de bestaande watergangen die het gebied draineren tot een systeem van oppervlakkig geultjes met een diepte van 0,20-0,30 m door suppletie met gebiedseigen materiaal of door het talud te verflauwen en daarmee de bedding te verhogen;

- benedenstrooms afkoppelen van bestaande watergangen die het gebied draineren en geen onderhoud meer aan plegen;

- grondgebruik intensieve landbouw wijzigen naar extensieve gebruiksvormen; buisdrainage verwijderen. 


\section{Maatregelen Snelstromende terrasbeken met zandbedding}

- piekafvoeren verlagen en basisafvoer verhogen door bufferende werking bovenstrooms kwelmoeras;

- beekloop verlengen door het stimuleren van het proces van meanderen door inbreng van doodhout, plaatselijke alternerende oeververlaging, lokale beddingsmalling met natuurlijk materiaal;

- natuurlijke beekloopverlegging (avulsie) door beverdammen toestaan (zie foto-omslag) en/of imiteren door de aanleg van houtdammen;

- beekloop verlengen door aanleg meanderbochten;

- ontstuwen (gefaseerd) in combinatie met tijdelijke inbreng van natuurlijke cascades;

- bodemophoging door zand- en/of grindsuppletie;

- bodemophoging door inbreng van doodhout;

- stimuleren van bosontwikkeling langs de beek door het (lokaal) achterwege laten van maai- en begrazingsbeheer.

\section{Maatregelen Kwelmoeras terrasvoet}

- op systeemniveau hydrologische maatregelen treffen om kwelstroom te stimuleren;

- bodemverhoging bestaande watergangen die het gebied draineren tot een systeem van oppervlakkig geultjes met een diepte van 0,20-0,30 m;

- benedenstrooms afkoppelen van bestaande watergangen die het gebied draineren en geen onderhoud meer aan plegen;

- grondgebruik intensieve landbouw wijzigen naar extensieve gebruiksvormen.

\section{Verlande restgeulen in het rivierenlandschap}

- de gehele restgeul betrekken bij de realisatie van het referentiebeeld;

- oeververlaging t.b.v. een brede moeraszone;

- bodemverhoging bestaande watergangen tot een diepte van 0,3-0,8 m;

- staken van het periodiek schonen en maaien van watergangen;

- invoeren van het adaptief stroombaanmaaien om knelpunten in de overgangsperiode te voorkomen. 


\section{Literatuur}

Bodemkartering, S. v., 1976. Bodemkaart van Nederland schaal 1 : 50 000; Toelichting bij de kaartbladen 45 Oost 's Hertogenbosch en 46 West - 46 Oost Vierlingsbeek. Wageningen, Stichting voor Bodemkartering.

Bont, Chr. de \& G.J. Maas, 2005. Tussen Grave en Gennep en Arcen en Velden; Archeologische verwachtingen langs de boorden en in het winterbed van de Maas in het stuwpand Grave en het stuwpand Sambeek vanuit fysisch- en historisch-geografisch perspectief. Alterra Wageningen 2005 Alterra rapport nr. 1174

Dekkers, J. M. J., 1997. De bodemgesteldheid van het landinrichtingsgebied Graspeel : resultaten van een bodemgeografisch onderzoek Wageningen, DLO-Staring Centrum. Rapport SC-DLO 517.

Delft, B. v., R. Kemmers \& R. de Waal, 2002. "Ecologische typering van bodems onder korte vegetaties : Het humusprofiel als graadmeter voor standplaatsontwikkeling." Landschap 19(3): 152-164.

Delft, B. v., R. d. Waal, R. Kemmers, P. Mekkink \& J. Sevink, 2006. Field guide Humus Forms; Description and classification of humus forms for ecological applications. Wageningen, Alterra.

Delft, S. P. J. v., J. Hof \& P. R. Bolhuis, 2012. Natuurpotenties in Drentse Beekdalen; Resultaten van een ecopedologisch en bodemchemisch onderzoek in zeven raaien in het dal van Drentse Aa en Elperstroom. Wageningen, Alterra WageningenUR. Alterra-Rapport 2315.

Delft, S. P. J. V., 2014. Ontwikkeling Blauwgrasland door plaggen in Oostelijke Vechtplassen; Selectie op basis van ecopedologisch en bodemchemisch onderzoek. Wageningen, Alterra Wageningen UR. Alterrarapport 2550.

Delft, S. P. J. v. \& R. W. d. Waal, 2015. Bodemonderzoek heischraal grasland Drouwenerzand; Ecopedologisch en bodemchemisch onderzoek voor maatregelen tot behoud en verbetering van de kwaliteit van heischraal grasland Wageningen, Alterra-WageningenUR. Alterra-Rapport 2651.

Delft, S. P. J. v., G. J. Maas \& R. W. d. Waal, 2015. "De Landschapsleutel OnLine." 2015, http://landschapsleutel.wur.nl/. Wageningen, Alterra - WageningenUR.

Engel, W., \& F. van Herpen, 2016. Watersysteemanalyse Raam. Onderdeel hydrologie; oppervlakte en grondwatersysteembeschrijving, ecologische sleutelfactoren. Nijmegen, Royal HaskoningDHV

Jongmans, A. G., M. W. v. d. Berg, M. P. W. Sonneveld, G. J. W. C. Peek \& R. M. v. d. Berg van Saparoea, 2012. Landschappen van Nederland; Geologie, bodem en Landgebruik. Wageningen, Wageningen Academic Publishers.

Kemmers, R. H., S. P. J. v. Delft, M. C. v. Riel, P. W. F. M. Hommel, A. J. M. Jansen, B. Klaver, R. Loeb, J. Runhaar \& H. Smeenge, 2011. Landschapsleutel; Leidraad voor natuurontwikkeling. Wageningen, Alterra, onderdeel van Wageningen UR. Alterra-rapport 2140.

Kleinsman, W. B., D. J. Groot Obbink \& H. J. M. Zegers, 1972. Ruilverkaveling Land van Cuyk : de bodemgesteldheid Wageningen, Stiboka. STIBOKA-Rapport 837.

Leenders, W. H. \& H. J. M. Zegers, 1974. Uitbreiding Ruilverkaveling Land van Cuyk : de bodemgesteldheid Wageningen, Stiboka. STIBOKA-Rapport 1099.

Makaske, B., en G.J. Maas, 2015. Handboek geomorfologisch beekherstel. Leidraad voor een stapsgewijze en integrale ontwerpaanpak. Amersfoort, Stowa, Stowa-rapportnummer 2015-02

Reeze, Bart, Alphons van Winden, Gijs Kurstjens, 2016. Ecologische streefbeelden. Ecologische verbindingszones, beekherstel, natuurvriendelijke oevers en overige wateren Waterschap Aa en Maas, 's Hertogenbosch.

Runhaar, H. \& S. Hennekens, 2014. 'Hydrologische Randvoorwaarden Natuur' Versie 3; Gebruikershandleiding. Wageningen, Nieuwegein, Utrecht, Alterra Wageningen UR, KWR Watercycle Research Institute, STOWA.

Schaminée, J. H. J., A. H. F. Stortelder \& E. J. Weeda, 1996. De Vegetatie van Nederland; Deel 3. Plantengemeenschappen van graslanden, zomen en droge heiden. Uppsala/Leiden, Opuluspress.

Schaminée, J. H. J., A. H. F. Stortelder \& V. Westhof, 1995a. De Vegetatie van Nederland; Deel 1. Inleiding tot de plantensociologie - grondslagen, methoden en toepassingen. Uppsala/Leiden, Opuluspress.

Schaminée, J. H. J., A. H. F. Stortelder \& V. Westhof, 1995b. De Vegetatie van Nederland; Deel 2. Plantengemeenschappen van wateren, moerassen en natte heiden. Uppsala/Leiden, Opuluspress. 
Schaminée, J. H. J., E. J. Weeda \& V. Westhof, 1998. De Vegetatie van Nederland; Deel 4. Plantengemeenschappen van de kust en van binnenlandse pioniermilieu's. Uppsala/Leiden, Opuluspress.

Stichting Voor Bodemkartering, 1976. Bodemkaart van Nederland schaal 1 : 50 000; Toelichting bij de kaartbladen 45 Oost 's Hertogenbosch en 46 West - 46 Oost Vierlingsbeek. Wageningen, Stichting voor Bodemkartering.

Stortelder, A. H. F., J. H. J. Schaminée \& P. W. F. M. Hommel, 1999. De Vegetatie van Nederland; Deel 5. Plantengemeenschappen van ruigten, struwelen en bossen. Uppsala/Leiden, Opuluspress.

Verdonschot, R.C.M., Runhaar, J., Buijse, A.D., Bijkerk, R. \& Verdonschot, P.F.M., 2016. Doorstroommoerassen en moerasbeken; typebeschrijvingen en ontwikkeling maatlatten voor de biologische kwaliteitselementen. Zoetwatersystemen. Wageningen, Zoetwatersystemen, Wageningen Environmental Research. p.

Waal, R. W. d. \& S. P. J. v. Delft, 2014. Bodemonderzoek Liefstinghsbroek; Ecopedologisch en bodemchemisch onderzoek voor maatregelen tegen de effecten van stikstofdepositie. Wageningen, Alterra Wageningen UR. Alterra-rapport 2580.

Wolfert, H.P., A. Corporaal, G.J. Maas, K. Maas, B. Makaske, P. Termes, 2009. Toekomst van de Vecht als een halfnatuurlijke laaglandrivier. Bouwstenen bij de grensoverschrijdende Vechtvisie 2009. Wageningen, Alterra-rapport 1897. 


\section{Bijlage 1 Fysisch- en historisch- geografische kaart van het Maasstuwpand Grave}
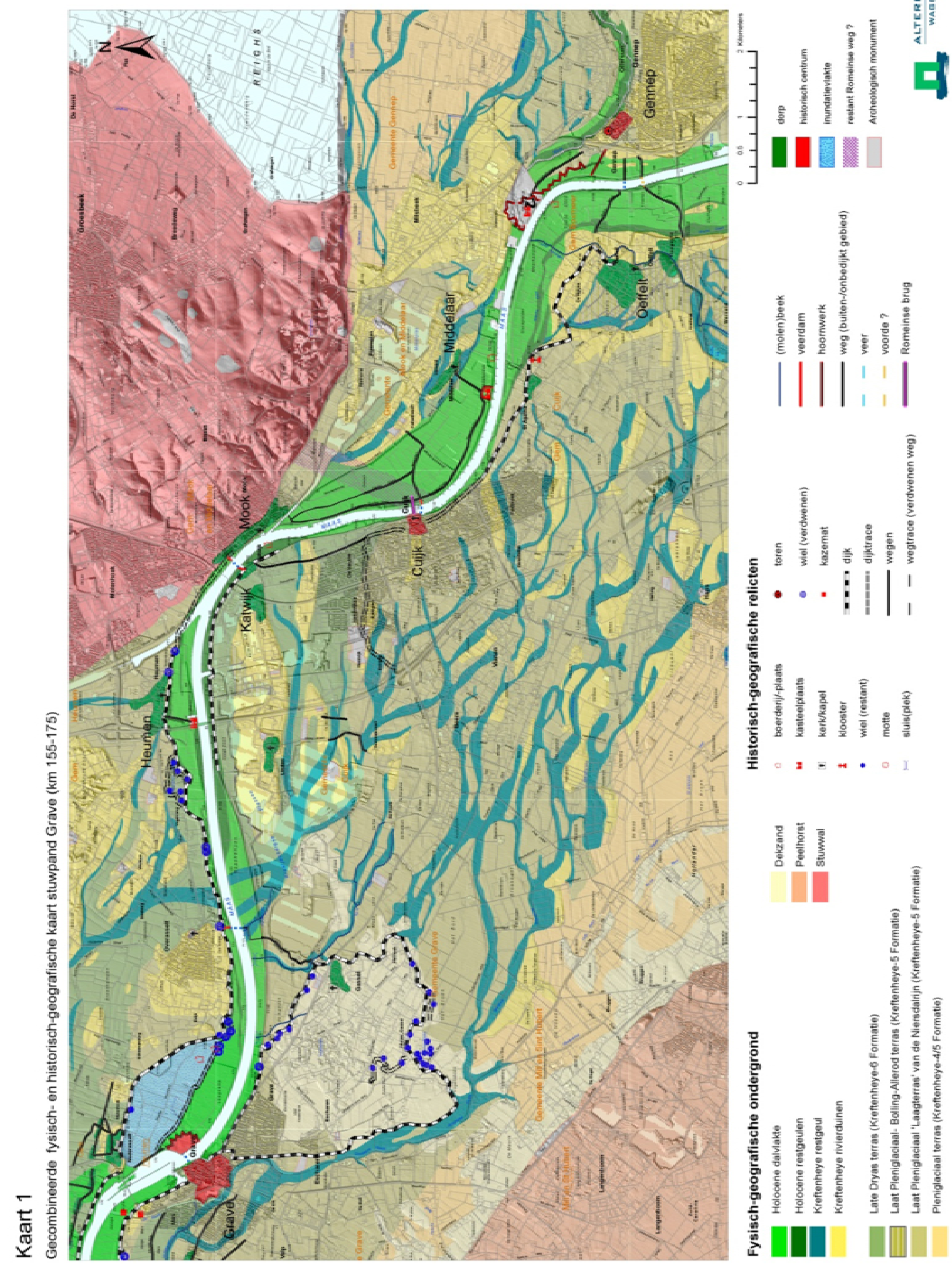

IIIIII
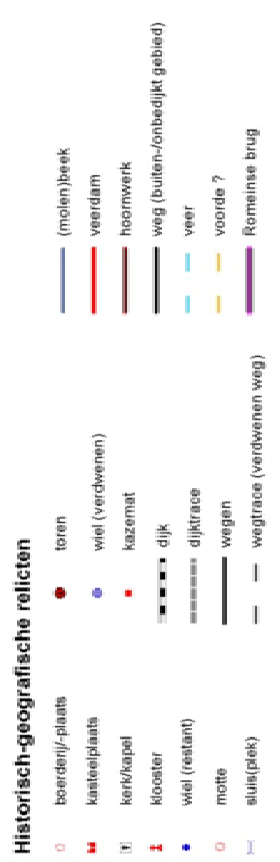

Uit: De Bont \& Maas (2005).

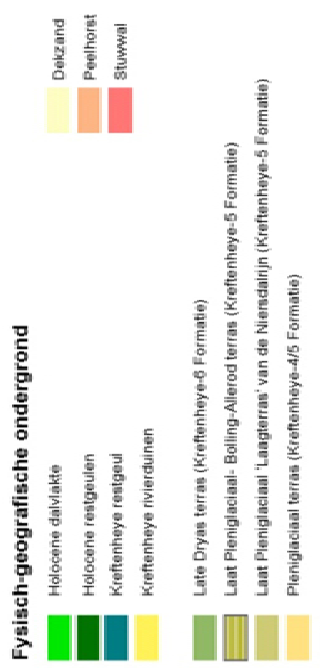




\section{Bijlage 2 Bodemkaarten}

Voor de Landschappelijke bodemkaart (zie §2.1.5) is gebruikgemaakt van de detailkarteringen (schaal 1 : 25.000) van de Landinrichtingsprojecten 'Land van Cuijk' (Kleinsman et al., 1972; Leenders \& Zeegers, 1974) en 'Graspeel' (Dekkers, 1997). De detailkarteringen zijn aangegeven binnen de rode kaders, daarbuiten is de Bodemkaart van Nederland gebruikt (Stichting voor Bodemkartering 1976).

Met rode stippen zijn de locaties aangegeven van vijf boringen die bij de veldverkenning op 24 november 2016 zijn beschreven. De profielbeschrijvingen zijn opgenomen in Bijlage 3.

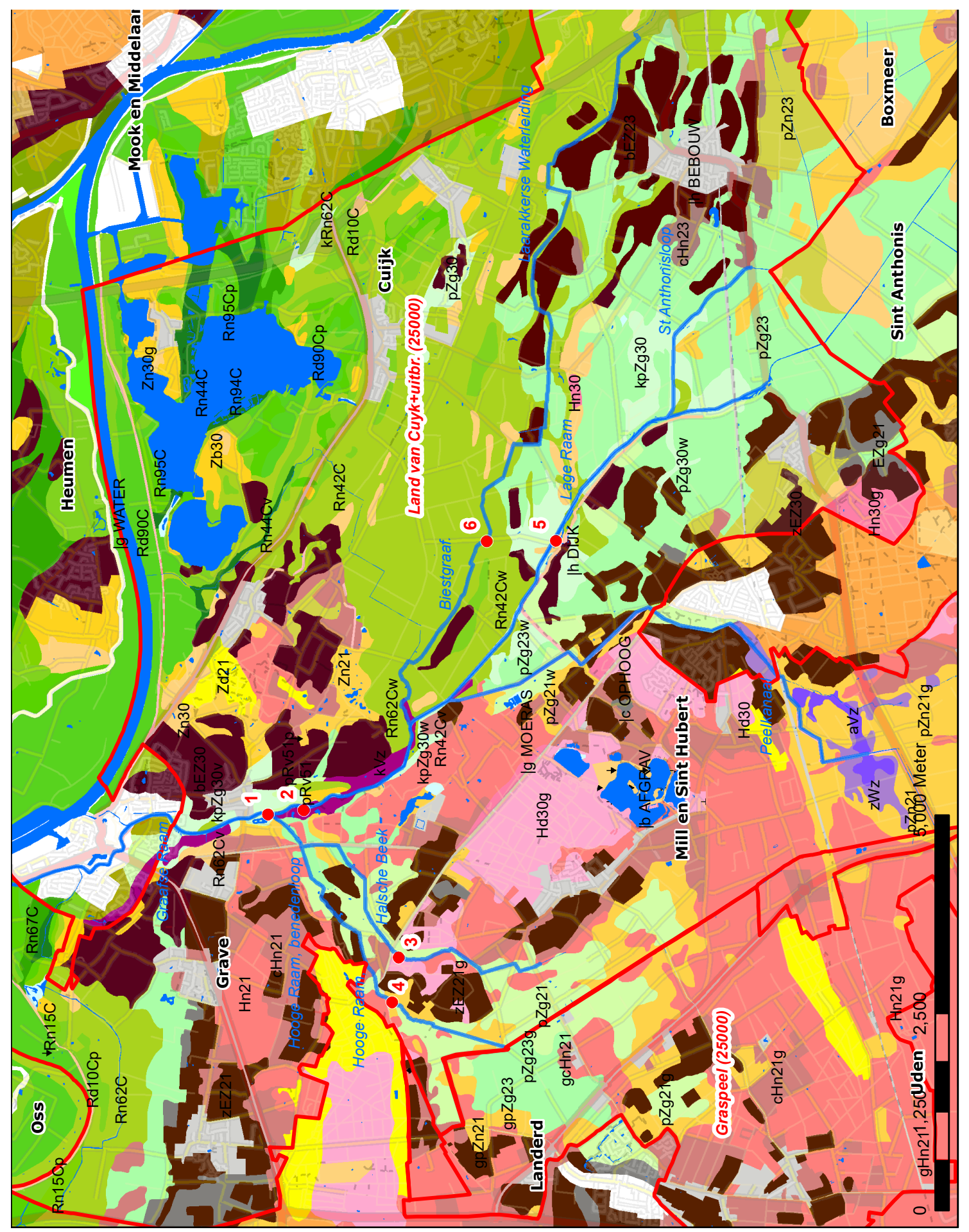



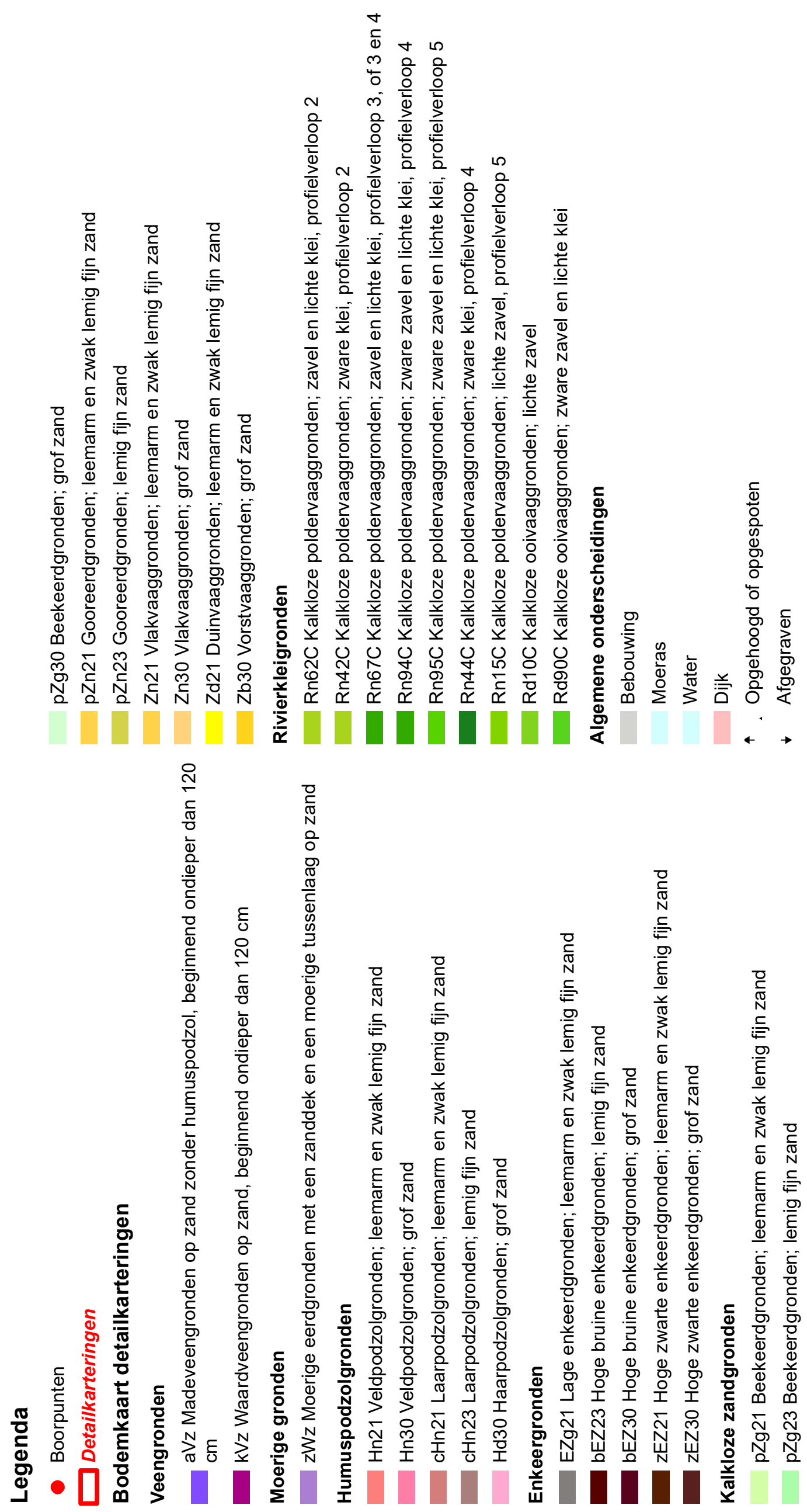


\section{Bijlage 3 Profielbeschrijvingen}

Profielbeschrijvingen bij vijf boringen die tijdens de veldverkenning op 26 november 2016 zijn gemaakt. De locaties zijn aangegeven op de bodemkaart in Bijlage 1. De resultaten zijn opgenomen in de factsheets in hoofdstuk 3.

\section{Algemene gegevens}

\begin{tabular}{|c|c|c|c|c|c|c|c|}
\hline 을 & 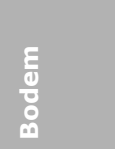 & $\ddot{U}$ & 논 & 它 & OPMERKING & $\mathrm{X}$ & $\mathbf{Y}$ \\
\hline 1 & Zn21 & VIo & 75 & 155 & Boven talud 3m van oever. geen veen gws 128 & 179565 & 416688 \\
\hline 3 & gZn30 & IIIb & 30 & 100 & $\begin{array}{l}\text { Douglasbos met adelaarsvaren. Klei ontbreekt aan andere } \\
\text { kant van de beek }\end{array}$ & 177749 & 415030 \\
\hline 4 & fpZg23 & IIIa & 20 & 110 & Oever Hooge Raam, opgestuwd. gws 96 & 177184 & 415112 \\
\hline 5 & $\mathrm{Zn} 21$ & IIa & 10 & 70 & Afgegraven zone tussen Lage Raam en Achterdijk & 183028 & 413040 \\
\hline 6 & Rn15C & Vbo & 35 & $>120$ & Oever Biestgraaf & 183022 & 413916 \\
\hline
\end{tabular}

\section{Laaggegevens}

\begin{tabular}{|c|c|c|c|c|c|c|c|c|c|c|c|c|c|c|c|c|}
\hline 을 & 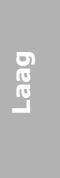 & & 苋 & $\begin{array}{l}\text { 릉 } \\
\text { 츤 } \\
\text { 오 }\end{array}$ & है & 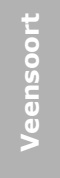 & $\frac{\mathrm{E}}{\mathrm{N}}$ & 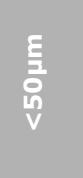 & & $\begin{array}{l}\frac{0}{10} \\
\frac{1}{2}\end{array}$ & 른 & 差 & $\frac{\text { 음 }}{\frac{5}{2}}$ & 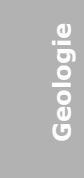 & & 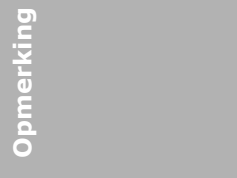 \\
\hline 1 & 1 & 1 & $0-70$ & $1 \mathrm{AC}$ & 1 & & 2 & & 11 & 165 & 0 & 0 & 1 & & 413 & bovenin droog \\
\hline 1 & 2 & 2 & $70-150$ & $1 \mathrm{Cg}$ & 0 & & 2 & & 11 & 165 & 0 & 0 & 1 & & 413 & roestig \\
\hline 1 & 3 & 3 & $150-220$ & $1 \mathrm{Cr}$ & 0.5 & & 2 & & 11 & 165 & 0 & 0 & 1 & & 413 & donkergrijs \\
\hline 2 & 1 & 1 & $0-20$ & 1Ahgc & 2 & & 12 & & 45 & & 0 & 0 & 1 & 5 & 322 & \\
\hline 2 & 2 & 2 & $20-40$ & $1 \mathrm{Cgc}$ & 0.2 & & 30 & & 30 & & 0 & 0 & 1 & 5 & 322 & zeer roestig \\
\hline 2 & 3 & 3 & $40-70$ & $1 \mathrm{Cgr}$ & 5 & & 20 & & 70 & & 0 & 1 & 1 & 4 & 322 & donkergrijs \\
\hline 2 & 4 & 4 & $70-110$ & $2 \mathrm{Cg}$ & 0 & & 2 & & 9 & 165 & 0 & 0 & 1 & & 413 & \\
\hline 2 & 5 & 5 & $110-170$ & $2 \mathrm{Cr}$ & 0 & & 2 & & 9 & 165 & 0 & 0 & 1 & & 413 & \\
\hline 3 & 1 & 1 & $-15--12$ & $1 \mathrm{Lv}$ & 90 & $\mathrm{~L}$ & 0 & & & & 0 & 0 & 1 & & 172 & \\
\hline 3 & 2 & 2 & $-12-0$ & $1 \mathrm{Fa}$ & 90 & $\mathrm{~L}$ & 0 & & & & 0 & 0 & 1 & & 172 & \\
\hline 3 & 3 & 3 & $0-30$ & $2 \mathrm{Ah}$ & 4 & & 5 & & 202 & 230 & 5 & 5 & 1 & & 333 & donkergrijs \\
\hline 3 & 4 & 4 & $30-60$ & $2 \mathrm{Cg}$ & 0 & & 3 & & 152 & 250 & 8 & 8 & 1 & & 333 & wat roestig \\
\hline 3 & & 5 & $60-120$ & $3 \mathrm{Cgr}$ & 2 & & 35 & & 30 & & 2 & 2 & 1 & 6 & 333 & donkergrijs taai \\
\hline 3 & & 6 & $120-150$ & $4 \mathrm{Cr}$ & 0 & & 0 & & 0 & 100 & 30 & & 1 & 6 & 333 & \\
\hline 4 & & 1 & $0-30$ & 1Aapg & 4 & & 6 & & 30 & 160 & 1 & 1 & 1 & & 340 & \\
\hline 4 & & 2 & $30-55$ & $1 \mathrm{ACgC}$ & 1 & & 6 & & 30 & 160 & 1 & 1 & 1 & & 340 & \\
\hline 4 & & 3 & $55-100$ & $1 \mathrm{Cg}$ & 0 & & 2 & & 9 & 165 & 0 & 0 & 1 & & 340 & \\
\hline 4 & & 4 & $100-110$ & $2 \mathrm{Cgr}$ & 30 & DK & 10 & & & & 0 & 0 & 1 & & 112 & \\
\hline 4 & & 5 & $110-170$ & $3 \mathrm{Cr}$ & 1 & & 2 & & 9 & 160 & 0 & 0 & 1 & & 413 & \\
\hline 5 & & 1 & $0-5$ & $1 \mathrm{Ah}$ & 3 & & 3 & 1 & 12 & 170 & 0 & 0 & 1 & & 331 & grijs \\
\hline 5 & & 2 & $5-70$ & $1 \mathrm{Ce}$ & 0 & & 3 & & 12 & 170 & 0 & 0 & 1 & & 331 & wit \\
\hline 5 & & 3 & $70-170$ & $1 \mathrm{Cr}$ & 0 & & 2 & & 8 & 180 & 1 & 1 & 1 & & 331 & lichtgrijs iets grind \\
\hline 6 & & 1 & $0-35$ & $1 \mathrm{Ah}$ & 2 & & 10 & & 45 & 165 & 0 & 0 & 1 & 5 & 331 & \\
\hline 6 & & 2 & $35-100$ & $1 \mathrm{Cg}$ & 0.1 & & 11 & & 45 & 170 & 0 & 0 & 1 & 5 & 331 & \\
\hline 6 & & 3 & $100-120$ & $1 \mathrm{Cgr}$ & 0 & & 5 & & 20 & 165 & 0 & 0 & 1 & & 331 & \\
\hline
\end{tabular}




\section{Bijlage 4 Potentiële vegetaties}

Overzicht van de potentiële vegetaties die volgens de Landschapsleutel op de in het gebied voorkomende Fysisch-Geografische typen verwacht kunnen worden, afhankelijk van de successiefase.

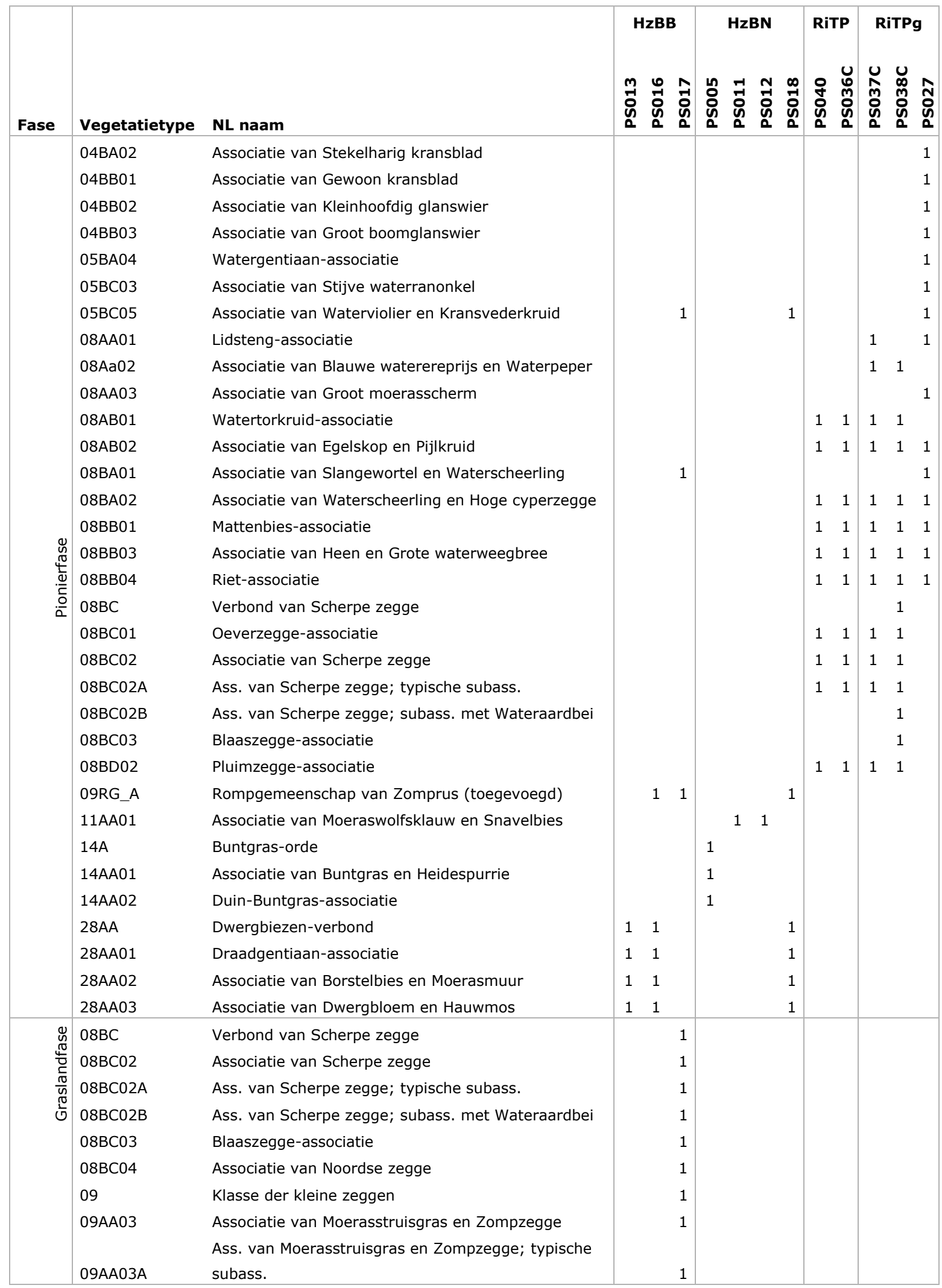




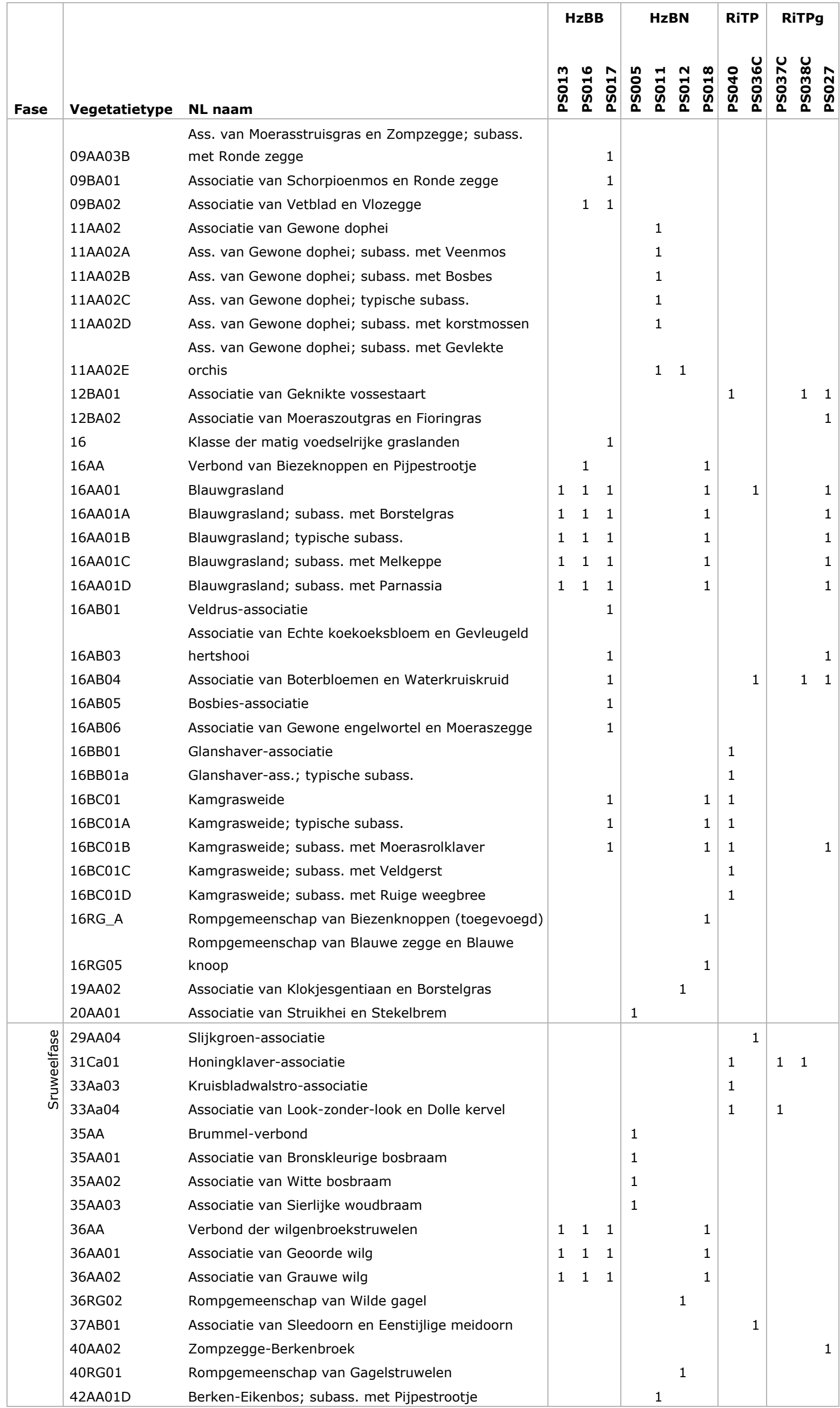




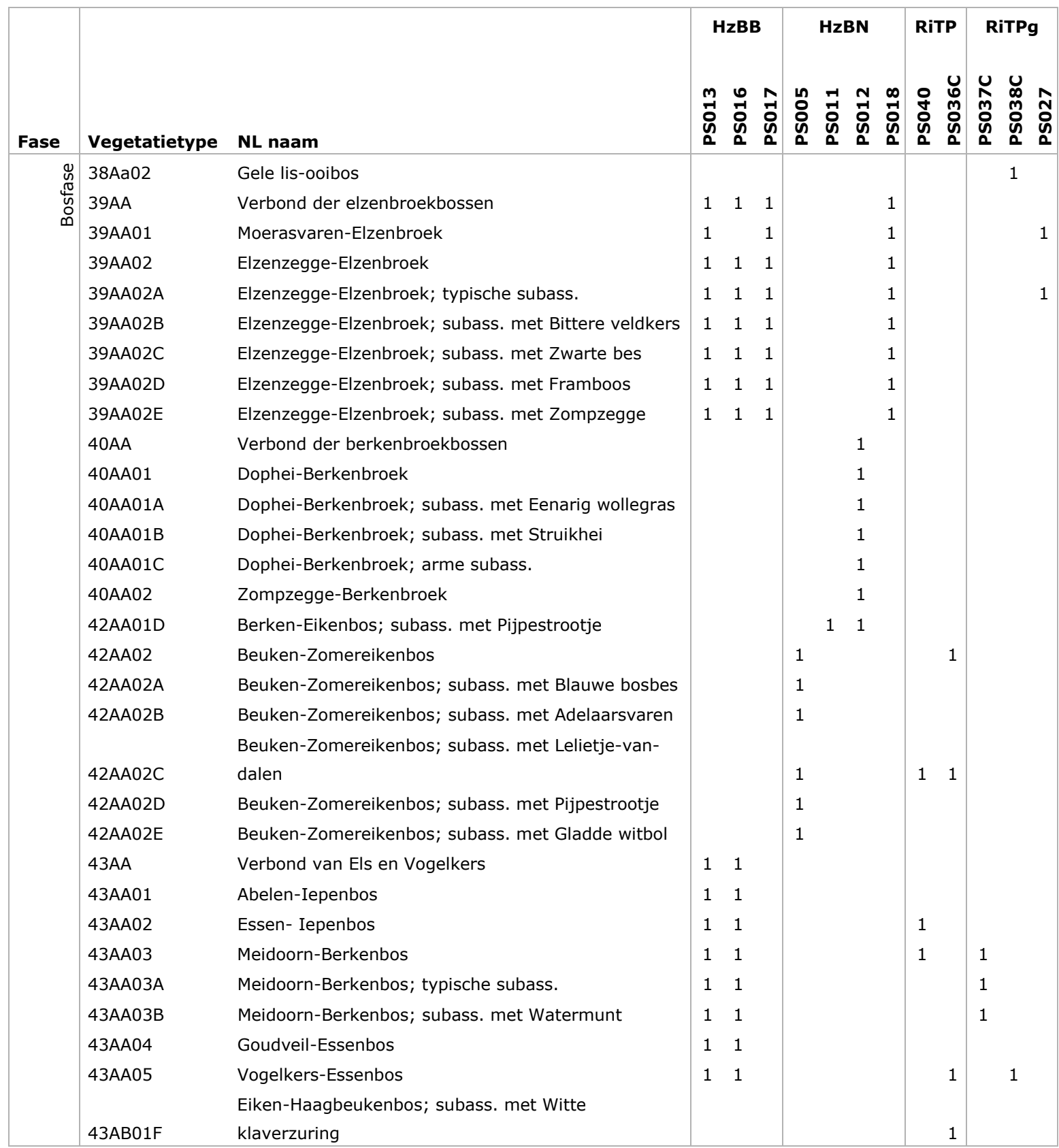


Wageningen Environmental Research Postbus 47

6700 AA Wageningen

T 0317480700

www.wur.nl/environmental-research

Wageningen Environmental Research Rapport 2918

ISSN 1566-7197
De missie van Wageningen University \& Research is 'To explore the potential of nature to improve the quality of life'. Binnen Wageningen University \& Research bundelen Wageningen University en gespecialiseerde onderzoeksinstituten van Stichting Wageningen Research hun krachten om bij te dragen aan de oplossing van belangrijke vragen in het domein van gezonde voeding en leefomgeving. Met ongeveer 30 vestigingen, 5.000 medewerkers en 10.000 studenten behoort Wageningen University \& Research wereldwijd tot de aansprekende kennisinstellingen binnen haar domein. De integrale benadering van de vraagstukken en de samenwerking tussen verschillende disciplines vormen het hart van de unieke Wageningen aanpak. 



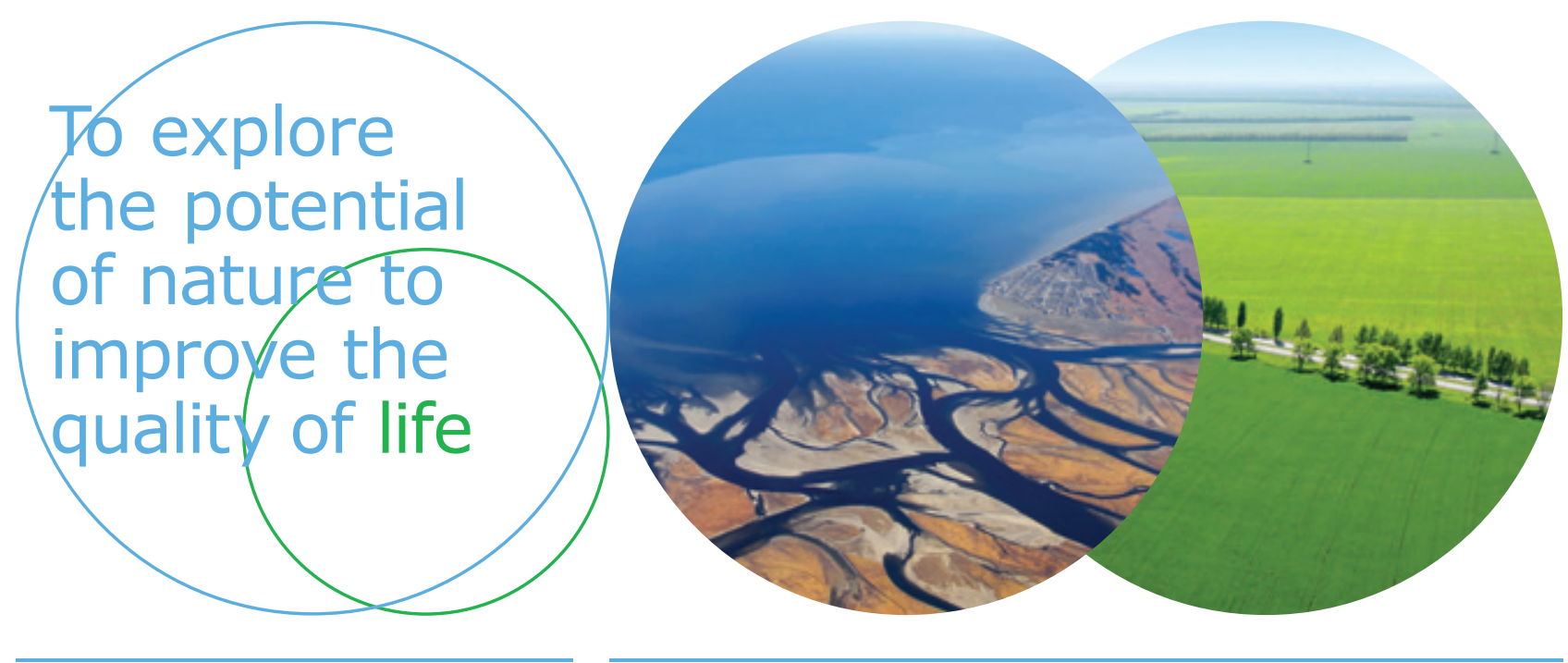

Wageningen Environmental Research Postbus 47

$6700 \mathrm{AB}$ Wageningen

T 317480700

www.wur.nl/environmental-research

Rapport 2918

ISSN 1566-7197
De missie van Wageningen University \& Research is 'To explore the potential of nature to improve the quality of life'. Binnen Wageningen University \& Research bundelen Wageningen University en gespecialiseerde onderzoeksinstituten van Stichting Wageningen Research hun krachten om bij te dragen aan de oplossing van belangrijke vragen in het domein van gezonde voeding en leefomgeving. Met ongeveer 30 vestigingen, 5.000 medewerkers en 10.000 studenten behoort Wageningen University \& Research wereldwijd tot de aansprekende kennisinstellingen binnen haar domein. De integrale benadering van de vraagstukken en de samenwerking tussen verschillende disciplines vormen het hart van de unieke Wageningen aanpak. 